\title{
Haiti: Enhanced Initiative for Heavily Indebted Poor Countries- Preliminary Document
}

This paper was prepared by staff of the International Monetary Fund and the World Bank in connection with the Executive Board's consideration of Haiti's preliminary assessment of eligibility for assistance under the Enhanced Initiative for Heavily Indebted Poor Countries. It is based on the information available at the time it was completed on August 16, 2006. The views expressed in this document are those of the staff team and do not necessarily reflect the views of the government of Haiti or the Executive Board of the IMF.

The policy of publication of staff reports and other documents by the IMF allows for the deletion of market-sensitive information.

To assist the IMF in evaluating the publication policy, reader comments are invited and may be sent by e-mail to publicationpolicy@imf.org.

Copies of this report are available to the public from

International Monetary Fund $\bullet$ Publication Services

700 19th Street, N.W. • Washington, D.C. 20431

Telephone: (202) 6237430 • Telefax: (202) 6237201

E-mail: publications@imf.org • Internet: http://www.imf.org

Price: $\$ 15.00$ a copy

\section{International Monetary Fund}

Washington, D.C. 



\title{
INTERNATIONAL DEVELOPMENT ASSOCIATION AND \\ INTERNATIONAL MONETARY FUND
}

\section{HAITI}

\section{Enhanced Initiative for Heavily Indebted Poor Countries-Preliminary Document}

\author{
Prepared by the Staffs of the \\ International Monetary Fund and the International Development Association \\ Approved by Ranjit Teja and Mark Plant (IMF) and \\ Pamela Cox and Daniel Leipziger (IDA)
}

August 16, 2006

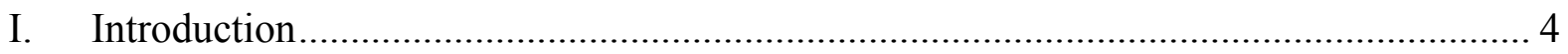

II. Background and Eligibility for HIPC Initiative Assistance............................................. 4

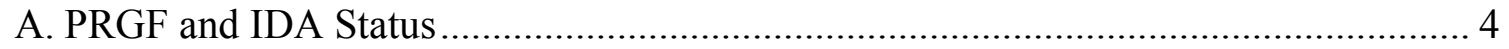

B. Poverty, Social and Political Developments ............................................................ 5

C. Policy Track Record and Reform Agenda …………............................................... 7

III. Medium-to-Long-Term Macroeconomic Framework ………………………................ 11

IV. Debt Sustainability Analysis (DSA) and Possible HIPC Assistance............................... 13

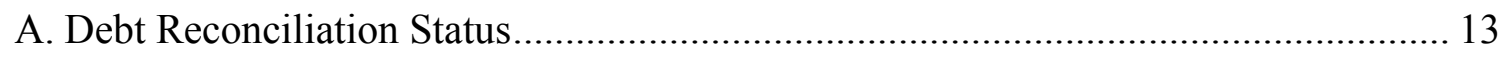

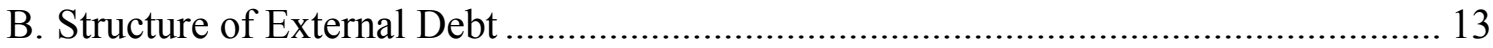

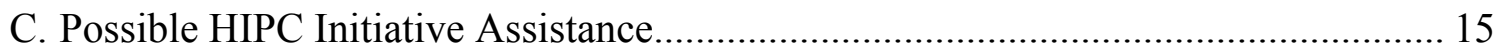

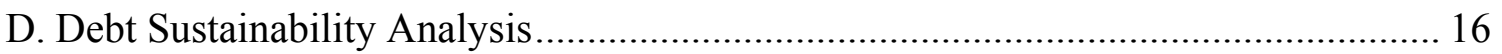

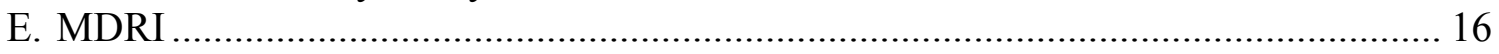

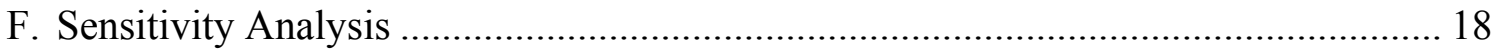

V. The Decision and Floating Completion Points ............................................................. 19

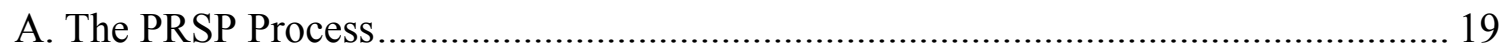

B. Possible Decision Point Timing................................................................................. 19

C. Possible Triggers for the Floating Completion Point …………………....................... 20

D. Monitoring the Use of HIPC Initiative Resources ...................................................... 22

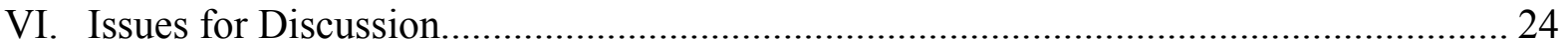




\section{Text Tables}

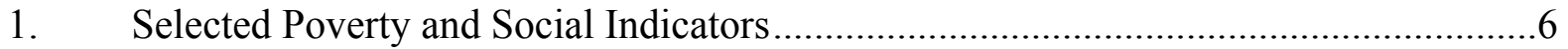

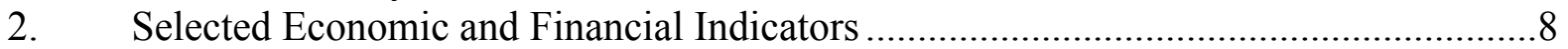

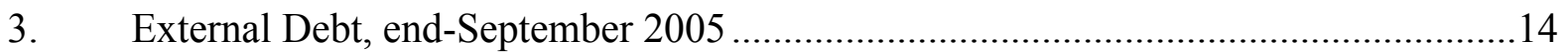

\section{Boxes}

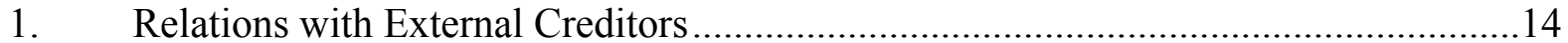

2. Key Macroeconomic Assumptions Underlying the DSA ...........................................17

3. Possible Triggers for the Floating Completion Point .................................................2.

4. Possible Expenditure Priorities for the Use of HIPC Debt Relief ...............................23

Figures

1A. Composition of Stock of External Debt at end-September 2005 by Creditor

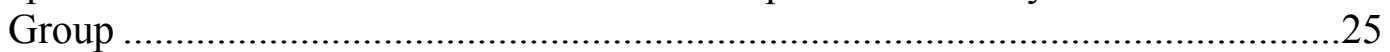

1B. Potential Costs of the HIPC Initiative by Creditor Group ........................................2.

2. External Debt Sustainability Indicators, 2005-25 ..................................................26

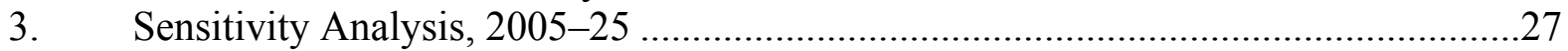

Projected Tables

A1. Nominal Stock and Net Present Value of Debt at end-September 2005 ....................28

A2. HIPC Initiative Assistance Under a Proportional Burden-Sharing Approach.............29

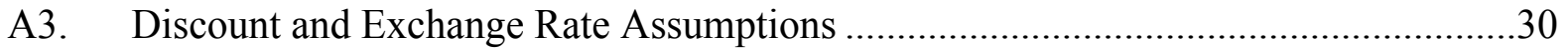

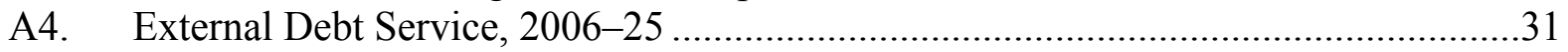

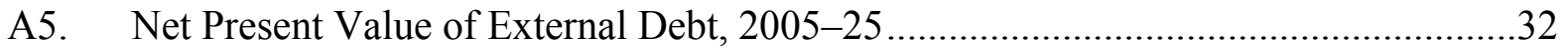

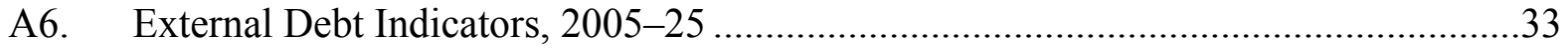

A7. External Debt Indicators and Sensitivity Analysis, 2005-25 ....................................34

A8. HIPC Initiative: Status of Country Cases Considered Under the Initiative...................35

A9. Possible Delivery of IMF Assistance Under the Enhanced HIPC Initiative .................36

A10. Possible Delivery of IDA Assistance Under the Enhanced HIPC Initiative ................37

A11. Long-Term Macroeconomic Assumptions, 2005-25 ..................................................38

Appendix

Debt Management Capacity. 


\section{Abbreviations and Acronyms}

\begin{tabular}{|c|c|}
\hline AIDS & Acquired Immune Deficiency Syndrome \\
\hline APN & Ports Authority \\
\hline BRH & Banque de la République d'Haïti (Central Bank of Haiti) \\
\hline CAMEP & Water Authority \\
\hline CEM & Country Economic Memorandum \\
\hline CNIMP & Interim National Commission for Public Procurement \\
\hline CPI & Consumer Price Index \\
\hline CSCCA & Supreme Audit Institution \\
\hline DSA & Debt Sustainability Analysis \\
\hline DHS & Demographic and Health Survey \\
\hline DMFAS & Debt Management Financial Analysis System \\
\hline GDP & Gross Domestic Product \\
\hline GNI & Gross National Income \\
\hline $\mathrm{EDH}$ & Electricity Utility \\
\hline EPCA & Emergency Post-Conflict Assistance \\
\hline EGRO & Economic Governance Reform Operation \\
\hline EGTAG & Economic Governance Technical Assistance Grant \\
\hline FER & Road Maintenance Fund \\
\hline HIPC & Heavily Indebted Poor Countries \\
\hline HIV & Human Immune-deficiency Virus \\
\hline IBRD & International Bank for Reconstruction and Development \\
\hline $\mathrm{ICF}$ & Interim Cooperation Framework \\
\hline IDA & International Development Association \\
\hline IDB & Inter-American Development Bank \\
\hline IMF & International Monetary Fund \\
\hline I-PRSP & Interim Poverty Reduction Strategy Paper \\
\hline JSAN & Joint Staffs Assessment Note \\
\hline MDB & Multilateral Development Bank \\
\hline MDG & Millennium Development Goal \\
\hline MDRI & Multilateral Debt Relief Initiative \\
\hline MEF & Ministry of Economy and Finance \\
\hline NPV & Net Present value \\
\hline NIR & Net International Reserves \\
\hline OPEC & Organization of Petroleum Exporting Countries \\
\hline PRGF & Poverty Reduction and Growth Facility \\
\hline PRSP & Poverty Reduction Strategy Paper \\
\hline SDR & Special Drawing Rights \\
\hline SMP & Staff Monitored Program \\
\hline TELECO & Telecoms Utility \\
\hline ULCC & Anti-Corruption Unit \\
\hline UNDP & United Nations Development Programme \\
\hline UNAIDS & United Nations Programme on HIV/AIDS \\
\hline UNCTAD & United Nations Conference on Trade and Development \\
\hline
\end{tabular}




\section{INTRODUCTION}

1. This paper presents a preliminary assessment of the eligibility of the Republic of Haiti (hereafter "Haiti") for assistance under the Enhanced Heavily Indebted Poor Countries (HIPC) Initiative. ${ }^{1}$ The assessment was based on several IDA and IMF staff missions to Port-au-Prince, most recently in June 2006. Together with the authorities, external debt data as of end-September 2005 has been reconciled and a preliminary debt sustainability analysis (DSA) has been conducted. The results indicate that Haiti's external debt burden would remain above the HIPC Initiative threshold after the application of traditional debt relief mechanisms. In order to qualify for HIPC debt relief, Haiti needs to continue the satisfactory implementation of the Emergency Post-Conflict Assistance (EPCA) supported macroeconomic program, agree on appropriate completion point triggers, and finalize its I-PRSP. Possible HIPC debt relief is estimated to be US\$139 million in endSeptember 2005 NPV terms and relief associated with the Multilateral Debt Relief Initiative (MDRI), also in NPV terms, is estimated at about US\$243 million. Debt relief under the HIPC Initiative and the MDRI would help Haiti accelerate progress towards the Millennium Development Goals (MDGs).

2. This paper is organized as follows. Section II provides background information on Haiti's eligibility for HIPC Initiative assistance; recent poverty, social and political developments; the policy track record to date; and the future reform agenda. Section III discusses the medium-to-long-term macroeconomic framework. Section IV summarizes the results of the preliminary DSA and possible HIPC and MDRI assistance. Section V suggests a timeline for the preparation of the decision point document, presents key reforms to be considered for the completion point triggers, and gives a preliminary indication of how prospective HIPC assistance will be used and its use tracked. Finally, section VI presents issues for discussion by Executive Directors.

\section{BACKGROUND AND ELIGIBILITY FOR HIPC INITIATIVE ASSISTANCE ${ }^{2}$}

\section{A. PRGF and IDA Status}

3. In October 2005, the Executive Board of the IMF approved DR10.25 million (about US\$14.7 million) in Emergency Post-Conflict Assistance (EPCA) to Haiti, adding to the SDR10.23 million (about US\$15.6 million) in EPCA provided in January 2005. When approving EPCA assistance, IMF Directors indicated their support for a rapid transition to a Poverty Reduction and Growth Facility (PRGF). Haiti is eligible to receive resources under

\footnotetext{
${ }^{1}$ The expressions HIPC Initiative and Enhanced HIPC Initiative will be used interchangeably hereafter to refer to the latter.

${ }^{2}$ Haiti was included in the list of potentially eligible countries in the HIPC ring-fencing document. See "Heavily Indebted Poor Countries (HIPC) Initiative - List of Ring-Fenced Countries that Meet the Income and Indebtedness Criteria at end-2004," April 11, 2006.
} 
the IMF's PRGF and discussions are ongoing between IMF staff and the Haitian authorities for a PRGF arrangement scheduled to be presented to the IMF Board in October 2006.

4. Haiti is an IDA-only country, with a GNI per capita of US\$450 in 2005 (using the World Bank's Atlas methodology). A Transitional Support Strategy was discussed by the IDA Board on January 6, 2005 and an Interim Strategy Note is currently under preparation. Haiti will continue to need substantial concessional assistance from the international community and is likely to remain an IDA-only country and eligible for PRGF resources for the foreseeable future.

\section{B. Poverty, Social and Political Developments}

5. Political and economic instability, recurrent deterioration in security, low growth, and high inequality and poverty have been the key challenges confronting Haiti in the past. The impact of prolonged political conflicts and violence, cycles of high external assistance followed by the withdrawal of economic support, and natural disasters has been severe. Real income per capita has declined on average by 2 percent annually over the past twenty years. Haiti's pattern of socio-economic development has been characterized by marked inequalities in access to productive assets and public services, which, together with low growth, has resulted in widespread poverty.

\section{Haiti is the poorest country in the Latin America and Caribbean region and} amongst the poorest in the world. About 54 percent of its population lives below the US\$1 a day poverty line and 78 percent below US\$2 a day (2001 data). The 2005 United Nations Human Development Index ranked Haiti 153rd out of 177 countries. An overwhelming share of the rural population lives in poverty. ${ }^{3}$ There are also large pockets of urban poverty in slum areas in Port-au-Prince, although many small cities and municipalities have lower poverty rates. Wide disparities exist regionally, with poverty being lowest in the Ouest region (34 percent), which includes the capital Port-au-Prince, and highest in the NordEst region (81 percent). Nonetheless, even in the Ouest region poverty is extremely high by international standards (higher than that of any country in Latin America and the Caribbean). Income inequality in Haiti is also among the highest in the Latin America and the Caribbean region, which in turn has higher levels of inequality than any other region of the world. Nearly half of national income goes to the richest 10 percent of the population. ${ }^{4}$

7. On social indicators Haiti ranks very low. Although adult illiteracy decreased from 60 percent in 1990 to 52 percent in 2003, it remains the highest in the Latin America and the Caribbean region and is higher than the average for low-income countries. Only 55 percent

\footnotetext{
${ }^{3}$ Incidence of poverty in rural areas is 69 percent for the US\$1 a day poverty line and 86 percent for the US\$2 a day poverty line.

${ }^{4}$ Estimates based on household surveys suggest that poverty and inequality rates have not changed substantially over the last two decades. Part of the explanation could be that, while GDP per capita declined, consumption levels were maintained by remittances which have accelerated since the mid-1990s.
} 
of children aged 6-12 are enrolled in school; in rural areas this indicator is even lower at 23 percent. Food deprivation and limited access to health care, due to poor infrastructure and lack of qualified personnel and drugs, have resulted in dire health conditions for Haiti's poor. Haiti also faces a high incidence of HIV/AIDS. UNAIDS estimates that 5.6 percent of the adult population has HIV. Despite all the risk factors in Haiti, there is some evidence that HIV/AIDS prevalence rates have not increased significantly in the last decade and may even have declined. UNAIDS credits this positive trend to close public-civil collaboration and sustained political commitment to contain the disease.

\section{The recent successful presidential and parliamentary elections provide an opportunity to overcome the legacy of past decades. A coalition government has been} formed, including ministers from different political parties. The coalition government received almost unanimous approval in Parliament, raising hopes for moving forward with an ambitious reform agenda to modernize the state and promote private sector investment. Both President Préval and Prime Minister Alexis have emphasized a number of priorities: primary education, rapid job creation, electricity, basic services in the urban slums, and a national development approach including all of Haiti's departments and communes. In his presentation of government policies to Parliament, Prime Minister Alexis stated that his government was committed to pursuing and deepening the economic governance reform agenda of the last two years and waging a war on corruption. These ingredients, in addition to strengthening security, are necessary if Haiti is to achieve the high, sustained and inclusive economic growth that is required to reduce poverty and bring about meaningful change in the living conditions of the Haitian population.

Table 1. Haiti: Selected Poverty and Social Indicators

\begin{tabular}{|c|c|c|c|}
\hline & Haiti & $\mathrm{LAC} \mathrm{1/}$ & LIC 2/ \\
\hline Population (million, 2002) $)^{3 /}$ & 8.3 & 540 & 2,615 \\
\hline Of which rural (\%) & 62.5 & 23.3 & 69.8 \\
\hline Annual population Growth (2003-15) & 1.4 & 1.3 & 1.6 \\
\hline Life expectancy at birth (Years, 2003) ${ }^{3}$ & 51.6 & 71.9 & 58.4 \\
\hline GNI per capita (2005 for Haiti, 2004 for LAC and LIC) ${ }^{4 /}$ & 450 & 3,576 & 507 \\
\hline $\begin{array}{l}\text { Incidence of Poverty (\% of the population below the US\$1 a day poverty line, } \\
2001 \text { data for Haiti; } 202 \text { data for LAC) }\end{array}$ & 53.9 & 8.9 & .. \\
\hline Adult literacy ratio ( $\%$ of people age 15 and above, 2003$)^{3 /}$ & 51.9 & 89.6 & 60.8 \\
\hline Primary school net enrollment ratio (\% of relevant age group, 2001) ${ }^{6}$ & 55 &.. & .. \\
\hline Infant mortality rate (per thousand, 2003) $3 /$ & 76 & 27 & 80 \\
\hline Child mortality rate (per thousand, 2002) & 118 & 32 & 124 \\
\hline Maternal mortality rate (per 100,000 live births, 2000$)^{5 /}$ & 680 & 194 & 682 \\
\hline Access to improved water source ( $\%$ of population, 2002$)^{3 /}$ & 71 & 89 & 77 \\
\hline Prevalence of HIV/AIDS (\% of persons age $15-49,2003)^{3 /}$ & 5.6 & 0.7 & 2 \\
\hline
\end{tabular}

1/ Latin American and the Caribbean (LAC) region.

2/ Low-Income Countries (LIC)

3/ UNDP, Human Development Report 2005.

4/ World Bank, 2006 World Development Indicators (for LAC and LIC). World Bank, staff estimates (for Haiti). Calculated using the

World Bank Atlas method.

5/ World Bank, 2006 World Development Indicators.

6/ World Bank, staff estimates based on the ECVH 2001 data. 


\section{However, setting Haiti on a path of economic recovery presents daunting} challenges. Economic recovery will critically require restored security, but a sustained improvement in security will in turn depend on the delivery of quick and visible improvements in the living conditions of the Haitian population. Also, strengthening public institutions and improving economic governance will be needed to ensure that economic growth is inclusive and sustained over time. The financial and technical support of the donor community will be critical to help the government address these challenges. While current conditions in Haiti present significant risks going forward, the provision of HIPC debt relief will contribute to creating fiscal space for much needed poverty-related expenditures and encourage reforms in public expenditure management.

\section{Policy Track Record and Reform Agenda}

10. Since mid-2004, Haiti's economic and social recovery and its structural reforms have been supported by donors under the Interim Cooperation Framework (ICF). ${ }^{5}$ The initial macroeconomic framework was established under the Fund's staff-monitored program (SMP) covering the period April-September 2004. Over the following two years, the authorities' macroeconomic program has been supported by the IMF's EPCA, with disbursements in January 2005 and October 2005. Following the clearance of arrears to IDA (US\$53.4 million) in early 2005, the government also received support from the World Bank to implement economic governance reforms (through an Economic Governance Reform Operation, EGRO, of US\$61 million and two Economic Governance Technical Assistance grants of US\$2 million each) and to support the country's recovery through community driven interventions, disaster prevention and management activities, and transport and territorial development programs. The Inter-American Development Bank (IDB) and bilateral donors have also provided significant financial and technical assistance.

\section{During 2004-06, Haiti has made significant progress toward strengthening} macroeconomic stability (see Table 2). The economy has gradually recovered from the shocks experienced in 2004 (political turmoil and severe floods), and annual GDP growth is expected to increase to 2.5 percent in FY2006 from 1.8 percent in FY2005. ${ }^{6}$ However, recurring security problems have adversely affected economic activity, donor project implementation and other inflows of foreign exchange. With increased revenues and tighter expenditure controls, the central government overall deficit (including grants) was reduced from 3.5 percent of GDP in FY2003 to a projected 1.1 percent in FY2006. This has largely eliminated recourse to central bank financing of the central government deficit. This substantial fiscal adjustment has also helped reduce end-of-period inflation from 38 percent in FY2003 to a projected 14 percent in FY2006; however this rate of inflation is still high relative to comparable low income countries. Net international reserves (NIR) have increased, raising import coverage from $1 \frac{1}{4}$ months of imports of goods and services in

\footnotetext{
${ }^{5}$ The ICF, presented by the government at the July 2004 donor conference in Washington, D.C., provided an interim framework until an elected government was in place.

${ }^{6}$ The Haitian fiscal year runs from October 1 to September 30. For example, FY2005 refers to the fiscal year 2004/05.
} 
FY2003 to an anticipated 1 1 $\frac{1}{2}$ months in FY2006. The authorities' program supported by the EPCA remains on track, and key end-June and end-September quantitative targets are likely to be met.

Table 2. Haiti: Selected Economic and Financial Indicators

\begin{tabular}{|c|c|c|c|c|}
\hline & \multirow[t]{2}{*}{$2002 / 03$} & \multirow[t]{2}{*}{$2003 / 04$} & \multirow[t]{2}{*}{$2004 / 05$} & $2005 / 06$ \\
\hline & & & & Proj. \\
\hline \multicolumn{5}{|c|}{ (Annual percentage change, unless otherwise indicated) } \\
\hline GDP at constant prices & 0.4 & -3.5 & 1.8 & 2.5 \\
\hline Real GDP per capita & -1.7 & -5.4 & -0.2 & 0.7 \\
\hline Consumer prices (end-of-period) & 37.8 & 21.7 & 14.8 & 14.0 \\
\hline \multicolumn{5}{|c|}{ (In percent of GDP) } \\
\hline Central government overall balance (including grants) & -3.5 & -2.4 & -0.4 & -1.7 \\
\hline \multicolumn{5}{|c|}{ (Changes in percent of beginning-of-period broad money) } \\
\hline Broad money (including foreign currency deposits) & 39.8 & 9.1 & 20.3 & 6.7 \\
\hline \multicolumn{5}{|c|}{ (Annual percentage change, unless otherwise indicated) } \\
\hline Net international reserves (in millions of U.S. dollars) 1/ & 38.8 & 54.5 & 70.6 & 109.0 \\
\hline Liquid gross reserves (in millions of U.S. dollars) 2/ & 157.1 & 207.4 & 228.5 & 312.5 \\
\hline In months of imports of the following year & 1.2 & 1.4 & 1.4 & 1.7 \\
\hline
\end{tabular}

Sources: Ministry of Economy and Finance; Bank of the Republic of Haiti; and Fund staff estimates.

1/ Excludes commercial banks' foreign currency deposits with the BRH.

2/ Gross reserves excluding capital contributions to international organizations.

12. Progress has also been achieved in the implementation of structural and economic governance measures, notably under the EPCA and EGRO. As of early 2004, Haiti was confronted with significant weaknesses in economic governance and management, which impeded the efficient use of both domestic resources and external financing. ${ }^{7}$ The main weaknesses were in the following areas: (i) budget formulation, execution and reporting; (ii) public procurement; (iii) public enterprise management and road maintenance;

(iv) human resource management; and (v) the financial sector. Progress in these areas are as follows:

\footnotetext{
${ }^{7}$ Reflecting these weaknesses, Transparency International's Corruption Perception Index (as well as other governance indices) has placed Haiti among the lowest rankings worldwide and has identified corruption as one of the leading constraint on economic growth and investment. See "La Fondation Héritage pour Haiti", L'Etat des Lieux de la Corruption en Haiti, 2003.
} 
- Budget formulation, execution and reporting. Prior to 2004, the government had at times operated without approved budgets or with budgets approved late into the fiscal year. Procedures for budget formulation and execution were weak and a significant share of public resources was channeled through multiple comptes courants held by individual ministries and used non-transparently. ${ }^{8}$ In addition, internal controls were impaired by the lack of a well-structured accounting system or external audits of government budgets. Recent government measures to address these weaknesses include: (i) passage of a new Organic Budget Law ${ }^{9}$ and adoption of a new budget classification and chart of accounts; (ii) approval of the budgets for FY2005 and FY2006 before the start of the fiscal year and regular public dissemination of key budget allocations and execution information; (iii) preparation of the FY2006 budget according to the new budget classification; (iv) a drastic reduction of discretionary spending through ministerial comptes courants; ${ }^{10}$ and (v) strengthening the external audit function with a decree on the organization and functioning of the supreme audit institution, the Cour Supérieure des Comptes et Du Contentieux Administrative (CSCCA). The CSCCA is in the process of catching up on government accounts audits which, together with the resumption of Parliament oversight functions, will strengthen external controls. Other measures have proceeded more slowly: (i) a mechanism for monitoring budgetary transfers to the electricity sector has been established but is not yet effective and an independent audit of the transfers has not taken place; and (ii) a survey of domestic payment arrears of the central government has been completed but not yet fully verified and a strategy to address them has not been formulated.

- In the early 2000s, public procurement operated under a 1989 decree which had not been fully implemented and had several flaws, and sole-source contracts and unadvertised bidding were the norm. Since 2004, the institutional framework for public procurement has been strengthened through: (i) the passage of a new Procurement Decree and the creation of the Interim National Commission for Public Procurement (CNIMP) in 2004; (ii) the preparation of standard bidding documents; and (iii) the publication of lists of government contracts and of a supplier database. The recent hiring of an international procurement consulting firm will help the CNIMP to strengthen procurement capacity in line ministries. Also, in 2004 an Anti-Corruption Unit (ULCC) was created and staffed as an autonomous entity under the Ministry of Economy and Finance (MEF). The Unit is conducting a comprehensive diagnostic survey of the state of governance and the perception of corruption in Haiti as an input to the design of a national anti-corruption strategy and has prepared a draft law for public sector employees' asset declaration. ${ }^{11}$ The

\footnotetext{
${ }^{8}$ The “comptes courants" (Ministries' accounts) are meant to be used for unexpected and non-budgeted needs such as for assistance to those affected by a natural disaster or unexpected travel by policy makers.

${ }^{9}$ In addition to establishing the outlines of a new budgetary process, the Law mandates the creation of a new accounting system, creates the position of internal ex-ante controllers and a new internal auditing office.

${ }^{10}$ The percentage of non-salary current public expenditures disbursed through comptes courants was reduced from 62 percent during October 2003-March 2004 to less than 10 percent from FY2005.

${ }^{11}$ The diagnostic survey was completed in March 2006. The final report is expected to be completed by endJuly, 2006.
} 
authorities have also supported the creation of a mechanism for civil society to monitor the implementation of economic governance reforms, in order to build demand for better governance and accountability.

- Public enterprises have been characterized by inadequate financial and operating practices and a lack of managerial accountability, often accompanied by the siphoning of budgetary resources. Due to the limited resources for maintenance and investment, the quality and reliability of services provided by these enterprises deteriorated over the years. Poor governance practices were particularly acute in the electricity (EDH) and telecoms (TELECO) utilities and the port authority (APN), which are critical for economic growth. In 2006, the government launched financial audits of APN, TELECO, EDH and the metropolitan water utility (CAMEP $)^{12}$ and an accounting rehabilitation of TELECO and EDH. In 2005-06, the government took a number of measures to strengthen the Road Maintenance Fund (FER), created in 2003 as the cornerstone of Haiti's road maintenance strategy. The FER now has reached a basic level of institutional capacity with the recruiting of key staff and the definition of its operational procedures.

- The inadequate quality and quantity of human resources have been one of the impediments to public sector efficiency in Haiti. This results from the scarcity of skilled people and the lack of an adequate incentive and accountability system to attract, maintain and motivate civil servants. Public sector employment in Haiti is very small by international standards. In 2004, public sector employment corresponded to 0.7 percent of the population, compared with 2 percent in Africa and 7.7 percent among developed market economies. ${ }^{13}$ Dealing with these shortfalls in a manner that supports sustained public sector efficiency will likely require increasing the efficiency of the use of scarce human resources and implementing reforms involving systemic restructuring of the civil service. In 2004, a new Civil Service Decree was enacted. A Coordination Unit in the Prime Minister's Office has taken on the human resource functions as a first step to overseeing the implementation of the Decree and a census of employment in selected ministries has been completed.

- Financial sector stability has been maintained, but weaknesses have been identified in the mechanism of monetary management and in financial audit and controls of the Central Bank of Haiti (BRH), and the BRH has experienced operational losses. The authorities are preparing a plan to address these weaknesses, including with technical assistance provided by the IMF. A draft of a new banking law will be finalized and submitted to parliament later this year. In addition, the financial statements of the BRH for the year ended September 30, 2004 were published, however with a year delay. The 2005 financial statements of the BRH have not yet been published. The BRH was also subject to a safeguards assessment in relation to drawings under the EPCA and the

\footnotetext{
${ }^{12}$ The audit of APN is complete and an action plan is being prepared to implement its recommendations. The audits of the remaining three enterprises are expected by August/September.

${ }^{13}$ Jaramillo (2005) “Public Sector Employment in Haiti” IMF Country Report No. 05/205.
} 
vulnerabilities identified by that assessment are now being addressed; and the BRH has strengthened its surveillance of credit cooperatives.

\section{The reform agenda going forward will be reflected in the I-PRSP currently under}

preparation. The government has expressed its commitment to maintaining macroeconomic stability and deepening economic governance reforms. In the budget, increased public expenditure will be linked to developing institutional capacity; the main focus will be increasing government revenues to underpin increases in spending for security, infrastructure, health and education. In the area of economic governance, the government intends to ensure effective implementation of the recently introduced legal and institutional framework described above. The focus will be on further enhancing budget management, public expenditure controls and procurement practices; improving management of public enterprises and road maintenance; strengthening human resource management; and supporting the mechanism for governance reform monitoring by civil society. In the financial sector, reforms will focus on improving the monetary policy framework and policy instruments to reduce inflation, reforming the auction mechanism for central bank bonds, recapitalizing the central bank and ceasing its non-core activities. In the education and health sectors, where private providers are dominant, reforms will focus on strengthening accreditation of private providers, introducing transparent and accountable financing mechanisms for poor families to pay the costs of non-public schooling and increasing resources to front-line providers. In addition, the government is defining other reforms, notably in the environment, infrastructure, and in sectors such as agriculture and tourism. Given the nature and depth of the challenges facing Haiti and the existing weak institutional capacity, results of all these reforms will be incremental and will take time, and sustained donor support will be critical.

\section{Medium-to-Long-Term MACROECONOMIC FrameWORK ${ }^{14}$}

14. Real output growth is projected to average 4.7 percent over the period 2006-25. In the short term, real output growth is projected to strengthen sharply, assuming significant improvements in security conditions, continued strong external support and increased public investment. Over the long term, real output growth is expected to stabilize at 5.0 percent. The expected improvement in real output growth in the long term will depend on maintaining security, sustained political and macroeconomic stability, progress on economic governance, and improvements in social and economic infrastructure, contributing to higher private investment, including FDI. While real GDP growth has been very low during the past half century, this largely reflects the impact of episodes of political instability. Excluding these shocks, Haiti experienced periods of high growth in the 1970s (annual average of about 5 percent) and in the second half of the 1990s (annual average of 4 percent). Growth was

\footnotetext{
${ }^{14}$ The macroeconomic projections used in this analysis cover the next 20 years and were prepared in consultation with the authorities. The medium- and long-term projections will be revised for the HIPC decision point document, according to the prospective final agreement on a PRGF arrangement which is expected to cover fiscal years 2007 to 2009 .
} 
fueled in the 1970s by investment in light manufacturing (notably the garment assembly industry) and tourism, while in the mid-1990s it reflected the rapid recovery following the end of the economic embargo during military dictatorship, and in particular a boom in construction and trade. ${ }^{15}$

15. Low and stable inflation is anticipated to foster an environment conducive to longterm growth. Over the past 10 years, inflation averaged 17 percent due to extensive use of central bank financing to cover large fiscal deficits. However, building on recent strengthening of fiscal discipline and change in the conduct of monetary policy, inflation is expected to decline gradually to 5-7 percent over the medium term from 15 percent in FY2005.

16. Macroeconomic stability is also expected to be supported by fiscal prudence. Over the projection period, the central government overall deficit is expected to average about 2.0 percent of GDP. The government is expected to increase revenues and seek concessional external financing to allow for increased pro-poor spending, higher investment and the institutional development of central and local governments, while maintaining debt sustainability after the delivery of HIPC Initiative assistance.

17. Fiscal revenues are projected to increase gradually to about $\mathbf{1 6}$ percent of GDP by FY2025, compared to about 9.3 percent over FY2004-06. The government is expected to implement measures to boost revenues, including through the establishment of customs control in the provinces (currently there is no effective central government authority in ports of entry other than Port-au-Prince); limiting industrial tax exemptions and other nonindustrial tax incentives; and enhanced computerization of tax and customs administration offices.

18. Government expenditures are expected to be re-oriented toward strengthening the institutional capacity of the government and increasing spending in key areas such as security, health and education. Rebuilding social and economic infrastructure will be the core of a comprehensive public investment program under preparation and is expected to be financed largely by external donors. The framework assumes that the share of pro-poor spending in overall outlays will increase in order to allow Haiti to make progress towards reducing poverty and meeting the MDGs.

19. For the long-term growth projection to materialize, Haiti's level of investment has to increase markedly, by about 6 percent of GDP over the projection horizon. ${ }^{16}$ Initially, higher investment will come from higher public investment, especially in public infrastructure, helping to create the conditions for private sector development. An

\footnotetext{
${ }^{15}$ Given that the long-term projection assumes that Haiti enters a path of restored security and economic recovery, the sensitivity analysis detailed in section E includes a scenario with lower growth.

${ }^{16}$ The investment numbers in the macroeconomic framework reflect the reporting in the Haitian national accounts, which may significantly overestimate investment as a share of GDP. Investment was reported at 27 percent of GDP in 2005.
} 
improvement in security is pivotal to ensure this outcome. As infrastructure constraints are gradually removed as a result of public investment, agricultural production and exports are expected to pick up. Improvement in hotel infrastructure would create favorable conditions for the tourism industry which notably caters to the large Haitian diaspora.

20. The external current account deficit (excluding grants) is expected to decline from over 8 percent of GDP in 2006 to about 5.6 percent of GDP at the end of the projection period largely due to improvements in net exports. Import ratios are projected to decline by 3.8 percentage points of GDP in the long term due to lower aid flows and increases in local production, e.g., in the agricultural sector. Rising exports are also expected to contribute modestly to the improvement in the current account (approximately 0.6 percentage points of GDP). ${ }^{17}$ International reserves are expected to increase from 1.6 months of imports of goods and services in 2005 to over three months from 2010.

\section{Debt Sustainability Analysis (DSA) And Possible HIPC Assistance}

\section{A. Debt Reconciliation Status}

21. The DSA presented below was prepared jointly by the authorities and the staffs of IDA and the IMF, based on loan-by-loan data provided by the authorities and creditors for public and publicly-guaranteed debt outstanding and disbursed as of end-September $2005 .^{1819}$ The reconciliation process was completed in June 2006, with 100 percent of multilateral and bilateral debt reconciled.

\section{B. Structure of External Debt}

22. Prior to the application of traditional debt relief mechanisms, Haiti's public and publicly guaranteed external debt was estimated at US\$1.3 billion in nominal terms as of end-September 2005 (Tables 3 and A1). Most of Haiti's external debt is on concessional terms with multilateral creditors representing 82.4 percent of the total, while bilateral creditors accounted for 17.6 percent (see Figure 1A). ${ }^{20}$ IDA and the IDB are Haiti's largest external creditors, representing approximately 38 percent and 40 percent of total claims, respectively. Italy, France and Spain are the largest bilateral creditors, with 5.2 percent,

\footnotetext{
${ }^{17}$ Exports of some agricultural products, such as mango and coffee, are expected to be strong, followed by exports of textiles and apparel industry, which are expected to be less robust given the ongoing changes in the world market following the phasing out of Multi-Fiber Agreement. A potential offsetting impact may result from the HOPE Act and possible future joint production arrangements with Dominican Republic producers. Nevertheless, an increase in textile sector exports or tourism would not lead to a substantial increase in net exports due to high import components.

${ }^{18}$ The DSA underlying the decision point document is expected to be based on the same loan-by-loan dataset.

${ }^{19}$ The debt data are based at end-September 2005, the end of Haiti's fiscal year.

${ }^{20}$ Haiti has no external commercial creditors.
} 
4.8 percent and 2.9 percent of total claims, respectively. Haiti's outstanding debt to Italy, France, and Spain includes arrears amounting to about US\$35 million (see Box 2). Non Paris Club creditors hold about 3.4 percent of Haiti's total external debt.

Table 3. Haiti: External Debt, end-September 2005 (in units indicated)

\begin{tabular}{lrr}
\hline & In US\$ million & \% of total \\
\hline Total & 1,332 & 100.0 \\
Multilateral & 1,098 & 82.4 \\
Bilateral & 234 & 17.6 \\
Paris Club & 189 & 14.2 \\
Other & 46 & 3.5 \\
Memorandum items & & \\
NPV of debt after & &.. \\
traditional debt relief & 926 &.. \\
(in \% of exports) & & \\
\hline
\end{tabular}

Sources: Haitian authorities and staff estimates

\section{Box 1. Relations with External Creditors}

Haiti has normalized relations with multilateral creditors. Following the Paris Club rescheduling agreement in 1995, Haiti remained current on external debt service payments through 1999. During 2000-03, however, the country accumulated arrears to most external creditors. Starting in July 2003, arrears to all multilateral creditors were cleared:

- In July 2003, Haiti cleared US\$32 million in arrears to the Inter-American Development Bank (IDB) using its own resources. This paved the way for renewed IDB lending and the IDB disbursed US\$35 million of a policy-based loan immediately afterwards. The IDB has followed up with additional US\$50 million in policy-based loans in 2004 and 2005.

- In 2004, Haiti cleared about US\$1 million in arrears to the International Fund for Agricultural Development (IFAD) and the OPEC Fund for Development.

- In January 2005, Haiti cleared US\$53.4 million in arrears to IDA using its own resources and a US\$6 million grant from Canada. IDA subsequently reengaged in Haiti, and provided US\$61 million in budget support (loans and grants) during 2005 and 2006.

Haiti has also sought to normalize relations with bilateral creditors, but arrears to three Paris Club creditors remain outstanding:

- In 2004, Haiti cleared arrears to US and Canadian official creditors to enable new disbursements and thus, net positive resource flows from these creditors.

- Haiti obtained an informal deferral on debt service payments from three Paris Club creditors (France, Spain, and Italy) during the program supported by the EPCA. These creditors have informally expressed their willingness to reschedule the debt service payments in the context of a PRGF arrangement, but assurances will be requested prior to the approval of the PRGF. The stock of arrears is estimated at US\$35.4 million as of end-September 2005 and is projected to increase to US\$42.3 million at end-September 2006. 


\section{Possible HIPC Initiative Assistance}

\section{Haiti's debt in NPV terms, after full application of traditional debt relief} mechanisms, is estimated at US\$926 million (as of end-September 2005). ${ }^{21}$ This is equivalent to 176 percent of exports of goods and services. ${ }^{22}$ Haiti is thus eligible for debt relief under the Enhanced HIPC Initiative's export window, having an NPV of debt-toexports ratio above the 150 percent threshold.

\section{The reduction of Haiti's NPV of debt-to-exports ratio from 176 percent to 150 percent would require HIPC debt relief of US\$139 million in NPV terms. This} implies a common reduction factor of 14.95 percent. Accordingly, the contribution to the US\$139 million in debt relief (in NPV terms) from multilateral creditors would be approximately US\$119 million, and about US\$20 million from bilateral creditors. Assuming the time profile and modalities presented below, this translates into about US\$205 million of nominal debt service relief over time. ${ }^{23}$ The following assumptions were made in projecting the time profile of possible HIPC Initiative assistance:

- IDA would provide total assistance amounting to US\$52.2 million in NPV terms, including an estimated US\$32.8 million related to the concessional rescheduling of arrears in early 2005. The concessional rescheduling of arrears is counted towards IDA's contribution to debt reduction under the HIPC Initiative, in line with the methodology agreed with the multilateral development banks (MDBs). ${ }^{24}$ Immediately following the approval of the decision point by the Boards of IDA and the IMF, IDA would begin to provide assistance in the form of debt-service reduction on debt outstanding and disbursed as of end-September 2005.

- IMF assistance would total US\$3.1 million in NPV terms. Immediately following the approval of the decision point by the Boards of IDA and the IMF, the IMF would extend interim assistance-provided that the necessary financing assurances are in place - in the form of debt-service reduction. However, due to relatively low levels of debt service falling due under the interim period, most of the IMF grant assistance is expected to be disbursed at the completion point, covering debt service during 2009-10.

\footnotetext{
${ }^{21}$ This includes the estimated impact of the concessional rescheduling of arrears by the World Bank (US\$32.8 million) and the IDB Group (US\$9.7 million), in line with standard Bank and Fund practices. Note that these figures are preliminary and could be revised at the decision point.

22 The NPV of debt-to-export ratio is calculated using a backward-looking three-year average of exports of goods and services. The 2005 observation of exports of goods and services remains preliminary.

${ }^{23}$ This does not include the assumed impact of the concessional rescheduling of arrears.

${ }^{24}$ See "HIPC Debt Initiative: the Chairman's Summary of the Multilateral Development Banks' Meeting," March 6, 1998, IDA/Sec M98-90.
} 
- All other multilateral creditors are assumed to provide debt-service reduction starting at the decision point or the completion point, until their contributions meet the requirement under the Enhanced HIPC Initiative.

- Paris Club bilateral creditors are assumed to provide a flow rescheduling on Cologne terms - i.e., a 90 percent NPV reduction - after reaching the decision point (assumed to take place in October/November 2006), with delivery of the remaining required assistance at the completion point through a stock-of-debt operation. The rescheduling on Cologne terms is expected to translate into US\$14.5 million in NPV terms.

- Comparable treatment would be provided by non-Paris Club official bilateral creditors.

\section{Debt Sustainability Analysis}

25. The macroeconomic assumptions used in this analysis reflect the framework underlying discussions for a possible PRGF-supported program and staff projections through 2025 and are summarized in Box $2 .^{25}$ The framework assumes rapid economic growth, underpinned by improved security and political stability, the decisive implementation of structural reforms, particularly in the areas of economic governance, and infrastructure improvement to promote private investment. The framework also assumes the continuation of sound macroeconomic policies, including maintaining fiscal prudence while increasing revenues and seeking concessional external financing.

26. On the basis of the assumptions described above and assuming the unconditional delivery of HIPC Initiative assistance, Haiti's NPV of debt-to-exports ratio is expected to fall gradually from 150 percent as of end-September 2005, to approximately 100 percent by 2025 (Table A5). ${ }^{26}$ The staff projection indicates that the ratio would remain consistently below the HIPC threshold of 150 percent during 2007-25. External debt service as a ratio of exports is also expected to decline gradually.

\section{E. MDRI}

27. Upon reaching the completion point under the HIPC Initiative, Haiti would qualify for MDRI debt relief from IDA, but is not expected to have eligible debt for MDRI debt relief from the IMF. ${ }^{27}$ MDRI debt relief would cover all outstanding debt disbursed from

\footnotetext{
25 The medium- and long-term projections will be revised for the HIPC decision point document, according to the prospective final agreement on a PRGF arrangement which is expected to cover fiscal years 2007 to 2009.

${ }^{26}$ Calculations based on staff projections for end-September 2006 suggest that Haiti's debt in NPV terms could be below 150 percent of exports of goods and services in 2007 without receiving HIPC Initiative assistance.

${ }^{27}$ For countries that had not yet reached the completion point when the MDRI was implemented (January 5 , 2006), the IMF has committed to provide stock relief under the MDRI on eligible debt to the IMF outstanding as of December 31, 2004 and still outstanding at the time of the completion point. Haiti is scheduled to repay all
} 
IDA prior to end-December 2003, and would start at the beginning of the quarter following confirmation of the country's eligibility by IDA's Executive Board. The amount of MDRI relief from IDA will depend on repayments made by the date of the completion point.

\section{Box 2. Key Macroeconomic Assumptions Underlying the DSA}

Key medium-to-long term macroeconomic assumptions used in the baseline DSA scenario include:

Annual real GDP growth averages 4.7 percent over the projection period (2006-25).

CPI inflation is projected to decelerate from 15 percent in 2006 to 5-7 percent in the medium run in line with projections for comparator countries.

Investment ratio is projected to increase by 6 percent of GDP in the long term. Public investment is expected to increase from about 4 percent of GDP in 2005 to about 8 percent of GDP in 2011.

Fiscal policy aims at achieving the government's spending priorities while maintaining macroeconomic stability. Central government revenue is expected to increase gradually from 9.6 percent of GDP in 2005 to about 16 percent of GDP by 2025. Expenditure is expected to increase to over 20 percent in the long term with an increased share of pro-poor spending in overall outlays. The central government overall deficit and external financing requirements, before HIPC Initiative assistance, are projected to average 2 percent of GDP over the projection period.

Official loan financing (excluding the IMF) is assumed to be mainly on concessional terms over the projection period, in line with historical experience. IMF loans are expected to be on PRGF terms. Other official loan financing is assumed to be mainly on concessional rates on terms comparable to IDA and the IDB (95 percent of total). The remaining 5 percent are assumed to be covered by bilateral donors on less concessional terms. The resulting grant element for new disbursements is estimated at about 45 percent.

External grants are expected to increase at a lower rate than GDP, declining from 8 percent of GDP in 2006 to 3.5 percent by 2025 , as the overall political situation and per capita GDP improve.

The external current account deficit (excluding external grants) is to contract from over 8 percent of GDP in 2006 to about 5.5 percent in the long run.

28. Assuming that Haiti reaches the completion point by end-September 2008, preliminary estimates indicate that MDRI debt relief from IDA could amount to US\$465 million in nominal terms (US\$243 million in NPV terms), excluding debt relief to be delivered under the HIPC Initiative. This compares with possible HIPC Initiative assistance of US\$205 million (US\$139 million in NPV terms). A one-year delay in reaching the completion point could result in Haiti forgoing about US\$9 million in debt relief, highlighting the importance of implementing the completion point triggers as quickly and thoroughly as possible.

eligible debt—debt that was outstanding to the IMF before December 31, 2004-by December 2006. Haiti is therefore not expected to have eligible debt for MDRI relief from the IMF at the completion point. 
29. The delivery of MDRI assistance would further reduce Haiti's external debt. Following the completion point, Haiti's NPV of debt-to-exports ratio would significantly fall, remaining within the 87-94 percent range over the projection period. ${ }^{28}$ Compared to a projection including only HIPC assistance, this represents a reduction of almost 40 percentage points at completion point (Table A6 and Figure 2).

\section{F. Sensitivity Analysis}

30. Simulations under three scenarios were conducted to test the sustainability of Haiti's external debt after HIPC Initiative assistance (Table A7 and Figure 2). Under the scenarios considered, Haiti's debt situation would worsen, and the debt indicators would breach the HIPC threshold in the scenarios with considerably lower export and GDP growth.

- The first scenario highlights the sensitivity of debt indicators to concessionality of new borrowing. Unlike the baseline scenario, new borrowing starting in 2006 and remaining in place throughout the projection period is contracted with an assumed 100 basis point increase in the interest rate paid. This would be equivalent to a reduction in the estimated combined grant element of new borrowing to 33 percent, compared to 45 percent in the baseline scenario. Export receipts are assumed to remain unchanged from the baseline scenario. Under this scenario, Haiti's NPV of debt-to-exports ratio slowly deteriorates compared to the baseline scenario, and stabilizes at about 120 percent from 2015.

- The second scenario considers the sensitivity of the projections to lower growth rates of exports of goods and services. In this scenario, exports are assumed to grow at a rate equivalent to the average over the last three years (12 percent) minus one standard deviation ( 7 percent). This implies a reduction in the average growth rate of about 3.5 percentage points compared to the baseline scenario. ${ }^{29}$ Lower export growth is also assumed to reduce government revenues, through lower GDP, and to subsequently increase the need for new financing. Based on these assumptions, the NPV of debt-to-exports, after assuming full delivery of HIPC Initiative assistance, would breach the HIPC threshold in 2014 and reach 196 percent in 2025 (Table A7). Compared to the baseline scenario, this represents a deterioration of approximately 2.0 percentage points in 2006, steadily increasing to almost 100 percentage points by 2025.

- The third scenario considers the sensitivity of the projections to lower GDP growth. In this scenario, GDP is assumed to grow 2.0 percentage points lower than the baseline growth rate of 4.2 percent and 5.0 percent for the decades $2005-15$ and 2016-25 respectively. Inability to significantly enhance security, improve social and

\footnotetext{
28 This assumes that MDRI has no impact on Haiti's new borrowing over the projection period.

${ }^{29}$ Although the average growth rates of exports over the past 20 years ( 11 percent) and the past 10 years (15 percent) were relatively high, they were also highly volatile, and additional uncertainties emerge from the on-going significant changes in markets for Haiti's exports noted above.
} 
economic infrastructure, and implement structural reforms would weaken private sector confidence and investment. The resulting lower growth would yield lower government revenues and the need for new borrowing would increase. Based on these assumptions, the NPV of debt-to-exports, after assuming full delivery of HIPC Initiative assistance, would slowly decline until 2013, reaching 121 percent. Thereafter, the NPV of debt-to-exports would gradually increase reaching 162 percent by 2025. Compared to the baseline scenario, this represents an increase in Haiti's NPV of debt-to-exports ratio of about 0.3 percentage points in 2006 increasing to 63 percentage points by 2025 .

\section{The sensitivity analysis indicates that Haiti's ability to service external debt after} HIPC relief is highly vulnerable to export performance. ${ }^{30}$ The achievement of a robust external debt position will be also dependent on real GDP growth and the composition and terms of external assistance. The analysis underscores the importance of strong and sustained government's and donors' efforts to: (i) re-establish internal security; (ii) provide a conducive environment for private investment, notably through infrastructure improvement and strengthening of state institutions, to develop exportable production (traditional and nontraditional); (iii) implement a prudent debt management strategy, including ensuring that external assistance is heavily weighted toward grants.

\section{The Decision And Floating Completion Points}

\section{A. The PRSP Process}

32. The I-PRSP is expected to be completed by the government by August-September 2006 and presented to the IMF and IDA Boards, together with the Joint Staff Advisory Note (JSAN), in October 2006, at the proposed time for the Decision Point Document. IDA and IMF staff provided comments on a first draft prepared in February 2006, which is now under revision by the new government to reflect its priorities and commitments.

\section{B. Possible Decision Point Timing}

33. In the staffs' view, Haiti's overall track record of macroeconomic stabilization and structural reforms since 2004 has been satisfactory for consideration for the HIPC decision point. Haiti has a favorable record under two comprehensive EPCA-supported programs (October 2004-September 2006), during which the authorities have made significant progress toward strengthening macroeconomic stability and implemented several key structural measures, thereby demonstrating Haiti's capacity to implement a medium-term reform program. The track record also includes economic governance reforms under

\footnotetext{
${ }^{30}$ However, the baseline and the sensitivity analysis scenarios do not consider the impact of MDRI debt relief or additional bilateral assistance. A more detailed analysis will be included in the decision point document.
} 
IDA-supported EGRO I (since January 2005). ${ }^{31}$ Although the two-year track record is relatively short, the HIPC framework has sufficient flexibility to accommodate Haiti's circumstances, including with regard to the length of track record to decision point. ${ }^{32}$ Based on the strength of the track record under the EPCA and EGRO noted above, the staffs are of the view that a relatively short track record of policy implementation is justified in the case of Haiti.

34. The staffs propose that the Decision Point document for Haiti be considered by the Boards of IDA and the IMF in October 2006, together with the approval of a PRGF arrangement by the IMF Board, conditional on (a) continued satisfactory implementation of the EPCA-supported macroeconomic program; (b) the reaching of understandings between the staffs and the authorities on the details of appropriate completion point triggers; and (c) the finalization of the I-PRSP. ${ }^{33}$

\section{Possible Triggers for the Floating Completion Point}

35. The previous analysis outlined key areas in which a program of economic governance and structural reforms, which would underpin HIPC and MDRI assistance, would support the economic and social development of Haiti. This program would focus on ensuring full and effective implementation of the legal and institutional framework introduced in the last two years, including: (a) strengthening public finance management, notably in the areas of budget management, public expenditure controls and procurement; (b) enhancing accountability of high public sector officials for their sources of income and assets and promoting governance and transparency in key public enterprises; and (c) increasing revenue mobilization through enhanced tax policy and administration. This agenda provides a framework for the choice of possible completion point triggers and IDA and IMF staffs have reached preliminary understandings with the authorities on their broad coverage (see Box 3$)^{34}$

\footnotetext{
${ }^{31}$ As indicated in IDA Report No. 35528 "Haiti Economic Governance Reform Operation—Release of the Floating Tranche-Full Compliance,” March 14, 2006.

${ }^{32}$ As recognized by the Development Committee in 2001, the existing framework of the Initiative is flexible and can accommodate special circumstances, including for post-conflict countries. See "Assistance to PostConflict Countries and the HIPC Framework”, Development Committee DC2001-0014, April 20, 2001. This comprises flexibility regarding the length and the content of the track record to reach the decision point. This document proposes that for post-conflict countries, the track record prior to the decision point should emphasize institution building and governance, and in the interim period the focus should be on developing mechanisms for tracking poverty-reducing resources. Assuming significant progress has been made towards governance capacity building, monitoring and macroeconomic stability, consideration could be given to having an early decision point combined with a relatively longer interim period. In that regard, the Executive Directors of IDA and the IMF have shown flexibility on the three years of satisfactory performance under IMF- and IDAsupported programs (of which one year should immediately precede the decision point) that are normally required to reach decision point. Note that Haiti met the conditions for post-conflict assistance from the IMF, but it is not classified as a post-conflict country under IDA procedures.

33 The I-PRSP and accompanying JSAN will be presented to the Boards with the Decision Point Document.

${ }^{34}$ More detailed triggers will be included in the Decision Point Document.
} 


\section{Box 3. Possible Triggers for the Floating Completing Point}

1. PRSP: Preparation of a full PRSP through a participatory process and satisfactory implementation of its recommended actions for at least one year, as evidenced by an Annual Progress Report submitted by the government to satisfaction of staffs of IDA and the IMF.

2. Macroeconomic Stability: Maintenance of macroeconomic stability as evidenced by satisfactory performance under the PRGF-supported program.

3. Public finance management and Governance: (a) Introduction of medium-term (three-year) macroeconomic framework and budget projections, consistent with medium-term pro-poor expenditures; (b) Adoption of an adequate classification for budget preparation and reporting to monitor government expenditures, in particular to establish a tracking mechanism for pro-poor expenditures and publication of reports; (c) Alignment of public spending priorities in accordance with the priorities identified in the IPRSP, and, when completed, the PRSP, reflecting emphasis on pro-poor growth; (d) Strictly limiting nonsalary current public expenditures spent through comptes courants; (e) Successive annual audits of Government accounts following acceptable audit standards completed by the Supreme Audit Institution, submitted to Parliament and publicly disclosed; (f) Adoption and satisfactory implementation of a new procurement law, promoting transparency and competition in line with international best practice;

(g) Adoption and satisfactory implementation of a law on asset declaration and disclosure for public sector employees; and (h) The key public enterprises (electricity, telecoms and the ports authority) are current on financial audits and have made satisfactory progress in the implementation of an action plan to address key audit recommendations.

4. Structural Reform: Strengthen tax policy and administration, for example, by establishing customs control in the provinces, broadening the VAT and personal income tax base, and introducing a unique taxpayer identification number.

5. Social sectors: (a) Education - Measures to improve quality and access to education, notably through increased public funding for education; the introduction of a public financing mechanism for poor families to pay the costs of non-public schooling; training of teachers; distribution of textbooks both to public and non-public schools; (b) Health- Measures to increase access and quality of health services and outcomes, i.e., increased child immunization rates, increased access to pre-natal care, increased number of Unités Communales de Santé providing the minimum services package, and increased supply of key drugs; and (c) HIV/AIDS-Mapping of primary new sources of the epidemic to guide future policy decisions, increased awareness and prevention campaigns, and improved care for persons infected.

6. External debt management: (a) Centralization of all information on public external and domestic foreign currency debt in a single database; (b) Publication of the quarterly external debt data, on a government website; and (c) Avoidance by the government, including the central bank, of long-term guarantees for public enterprise debt (external and in foreign currency).

36. The areas of triggers indicated above would be complemented by standard triggers including implementation of the PRSP and the maintenance of macroeconomic stability measures to increase access to and quality of education, health and HIV/AIDS services and outcomes. The reforms aim at strengthening the conditions for pro-poor growth and at facilitating progress towards the achievement of the MDGs. Should Haiti remain on track with regards to implementation of its poverty reduction strategy and economic reforms 
supported by IDA and the IMF, the HIPC completion point could be reached within two years of the HIPC decision point.

\section{Monitoring the Use of HIPC Initiative Resources}

37. Securing the effective use of debt relief assistance for poverty reduction and, more generally, the capacity to implement and monitor a shift in the composition of expenditure toward poverty-related objectives is a key element of the HIPC Initiative. The government intends to ensure the effective use of resources made available by the HIPC Initiative while continuing its ongoing efforts to strengthen the programming, management and control of public expenditure, and to improve service delivery in key sectors.

38. A joint IMF and IDA Assessment and Action Plan (AAP) for tracking poverty related expenditure in June 2006 concluded that while Haiti does not have a budget classification by program or a fully functional budget classification, there are mechanisms in place that can be used to adequately monitor the use of resources made available by the HIPC Initiative. The recently introduced budget and accounting classifications allow monitoring of budget allocations and expenditures following four dimensions: (i) institutional (executive, legislative, judiciary and autonomous entities); (ii) sectoral (economic, political, social, cultural and other); (iii) administrative (ministries, central and regional departments) including development projects; and (iv) economic (expenditure types). The budget is also presented in the annexes of the budget law following a functional classification with 10 broad categories (such as education and health). The functional classification is prepared from broad estimates from the administrative classification. Also, in the absence of a program budget, projects are individually coded within the administrative classification allowing recording and reporting on projects' expenditures.

39. On the basis of the AAP recommendations, the use of resources made available by the HIPC Initiative prior to completion point will be monitored at the entity (e.g., ministries, public institutions, and executing agencies) and the project levels. Entities, which are already coded in the budget classification, will be identified according to their core mandate in relation with poverty reduction. The same process will be followed to identify individual projects in areas which contribute to poverty reduction as defined in the I-PRSP currently under preparation. Possible expenditure priorities for the use of HIPC resources are provided below (see Box 4) and will be further discussed and specified with the authorities in the decision point document. The relatively limited resources from HIPC initiative assistance would focus largely on health and education, while other areas, such as infrastructure, would be financed by external resources. There are already mechanisms in place to record expenditures according to their destinations. This will allow monitoring both budget allocations and expenditures for both the entities and projects identified as contributing to poverty reduction. 


\section{Box 4. Possible Expenditure Priorities for the Use of HIPC Debt Relief}

\section{Education}

- Education for All (EFA) program.

- Provision of textbooks, teaching material and uniforms.

- School feeding program.

Health

- Improving the availability of drugs, immunization programs (including in remote areas using mobile brigades), prevention campaigns against malaria, parasite control in schools.

- Surveys on the prevalence of iodine and micronutrient deficiencies and programs to address these deficiencies.

- Equipment and supplies for maternity wards of health centers and hospitals.

- HIV/AIDS prevention and general health education activities.

- Strengthening epidemiology services.

Water Supply and Sanitation

- Improving access to potable water and sanitation for poor urban and rural households.

Environment

- Environmental protection and natural disaster prevention activities.

40. The periodic budget execution reports published by the MEF on its web page provide a tool to monitor and publicly disseminate the use of resources made available by the HIPC Initiative in-year. Measures are also being taken to become current with the audit of the annual government accounts by the CSCCA. This will provide external and independent validation of the budget execution reports. In addition, and as indicated above, the government continues its efforts to enhance programming, management and control of public expenditure with the support of technical and financial assistance from IDA, IMF, IDB and other donors.

41. The poverty-related programs and projects to be financed within the interim assistance would need to be included in the FY2007 and subsequent budgets. The authorities have defined possible expenditure priorities for the use of HIPC debt relief (Box 4) in line with its incoming I-PRSP and taking into account that resources from HIPC relief will be modest. Priority was given to programs which will help Haiti move towards the achievement of the MDG's. Given the significant existing gaps in development indicators, Haiti is unlikely to achieve the MDGs by 2015. However, with the continued external financial assistance (including HIPC and MDRI relief) Haiti could reach some MDGs, notably goal 2 (achieve universal primary education) and goal 7 (Combat HIV/AIDS, malaria and other diseases) and progress towards reaching the others. ${ }^{35}$

\footnotetext{
${ }^{35}$ The expenditure priorities for use of HIPC debt relief will be further discussed with the authorities during the preparation of the decision point document.
} 


\section{ISSUES FOR DISCUSSION}

42. This paper presents a preliminary assessment of Haiti's eligibility for assistance under the Enhanced HIPC Initiative. Executive Directors' views and guidance are sought in particular on the following issues:

- Eligibility: Do Directors agree that Haiti is eligible for assistance under the Enhanced HIPC Initiative?

- Timing of the Decision Point: Do Directors agree that Haiti could reach its Decision Point by October 2006, together with the approval of a PRGF arrangement by the IMF Board, provided that (i) the country remains on track with its macroeconomic program, supported by the EPCA; (ii) understandings are reached on appropriate completion point triggers; and (iii) the I-PRSP is finalized?

- Floating Completion Point: What are the Executive Directors' views on possible triggers and key policy measures (against which satisfactory performance would have to be measured) linked to the floating completion point? 
Figure 1A. Republic of Haiti: Composition of Stock of External Debt at End-September 2005 by creditor group

(Nominal stock: \$1.332 million)

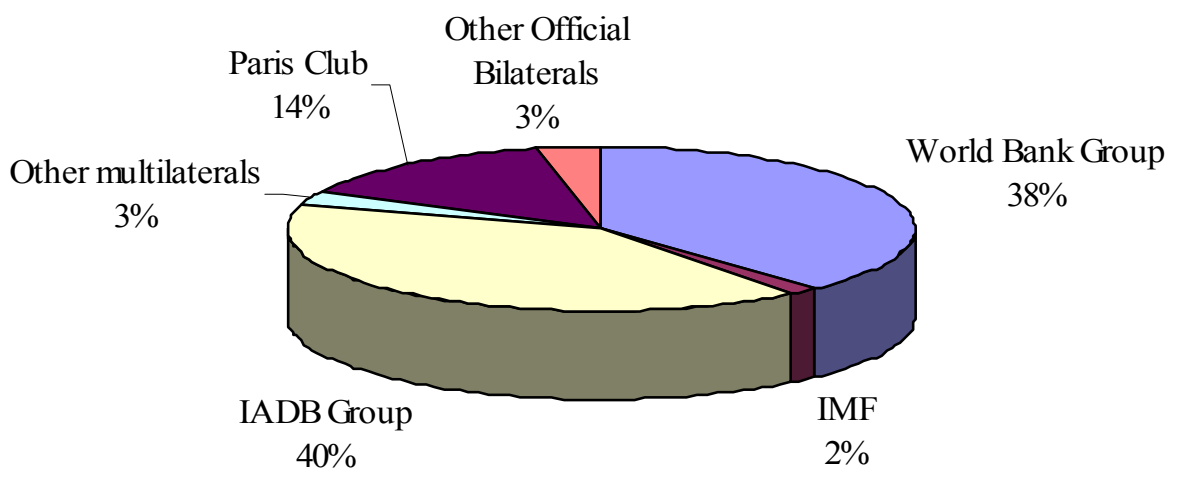

Figue 1B. Republic of Haiti: Potential costs of the HIPC Initiative by creditor group

(Total Estimated HIPC Enhanced Assistance: \$139 million, end-September 2005 NPV terms)

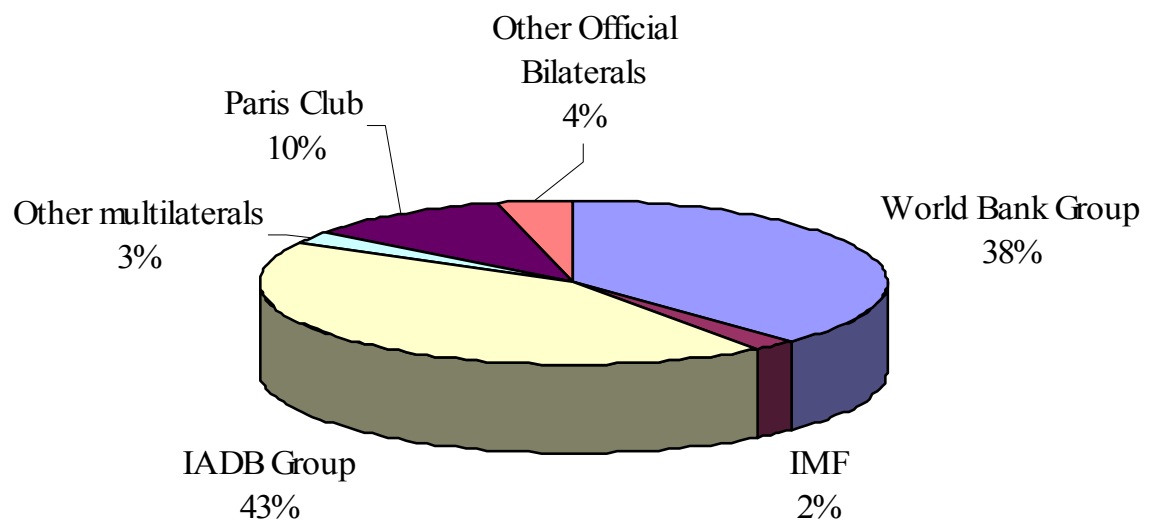


Figure 2. Republic of Haiti: External Debt

Sustainability Indicators, 2005-25

NPV of Debt to Exports

(In percent of Exports)

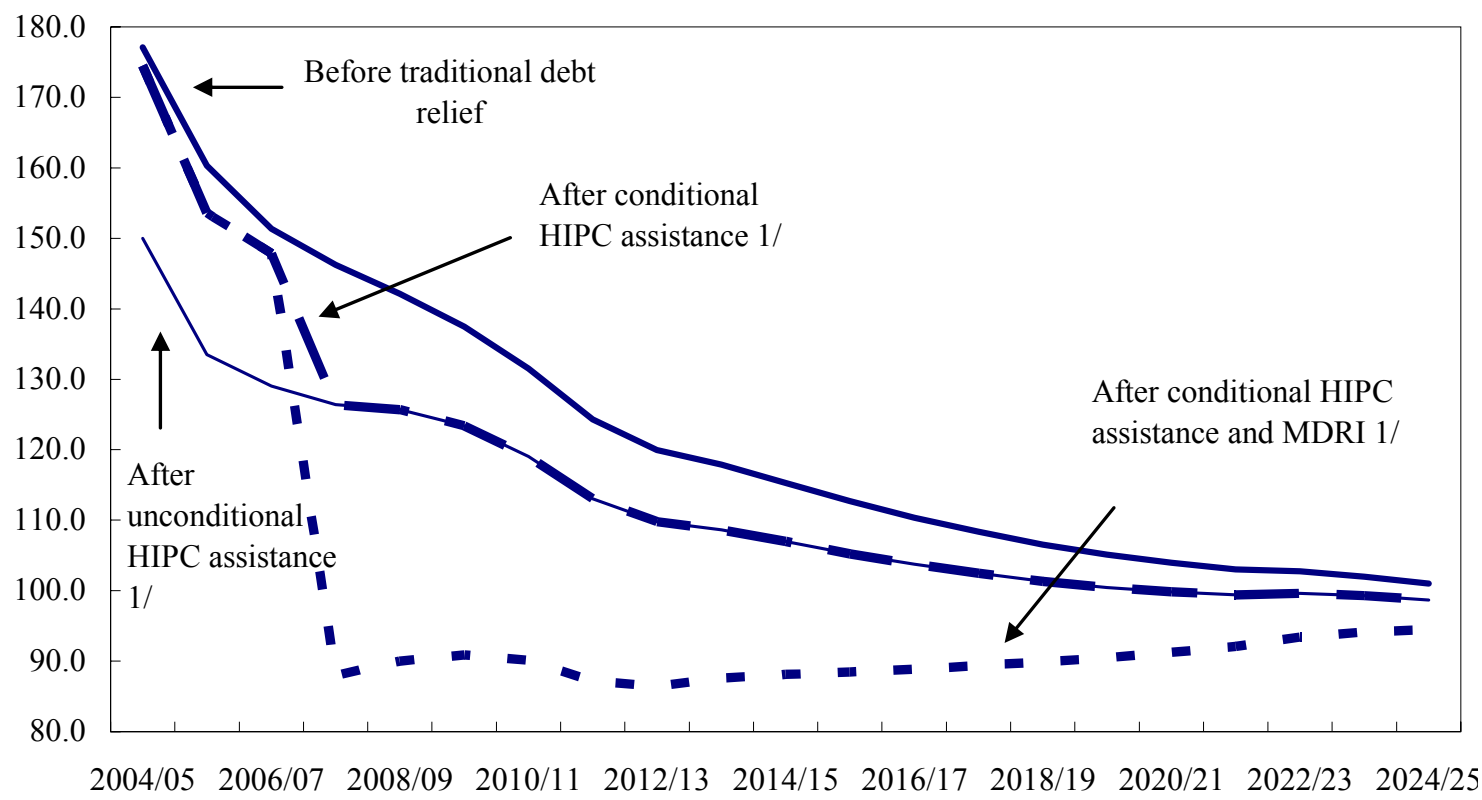

Debt Service to Exports

(In percent of Exports)

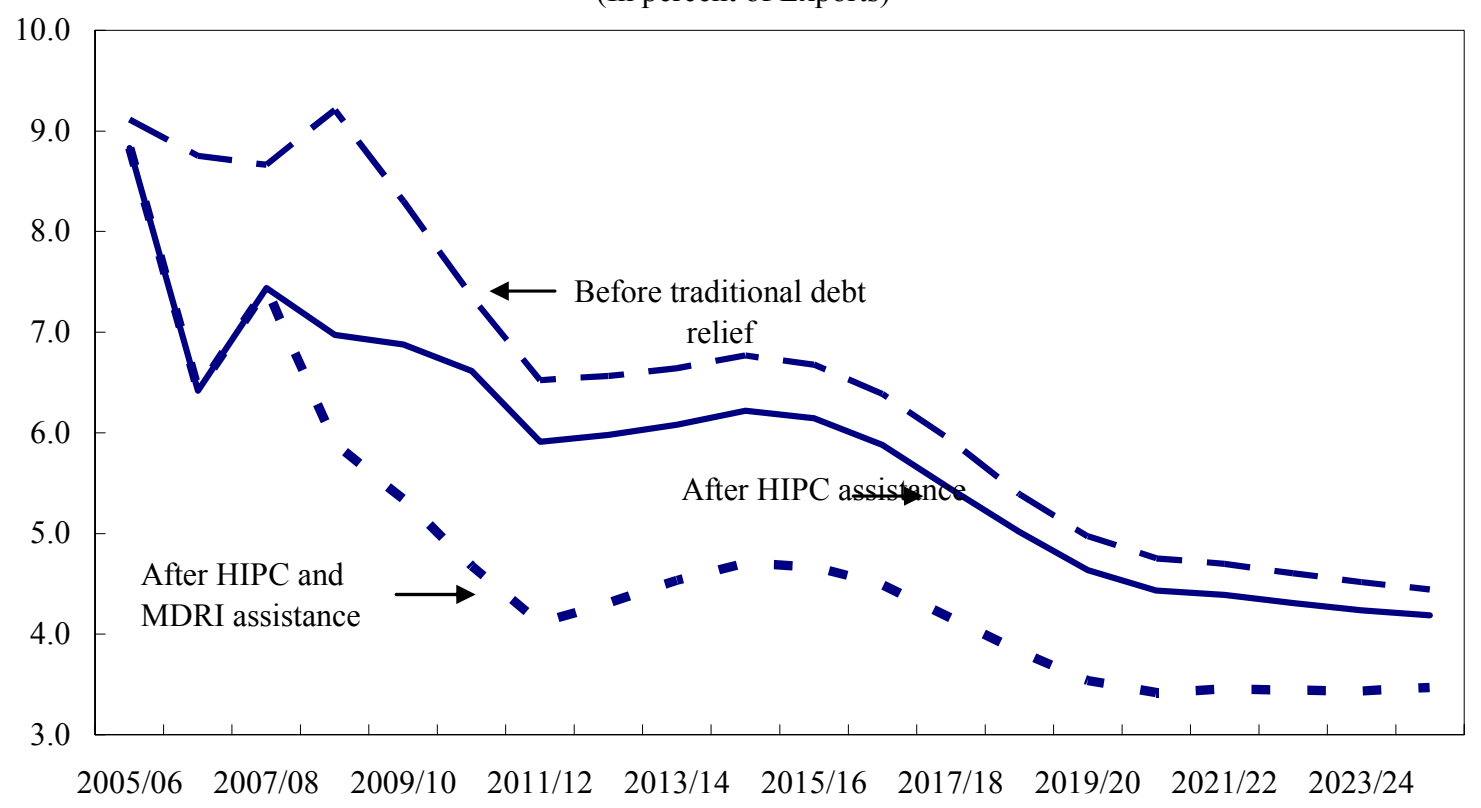

Sources: Haitian authorities and staff estimates and projections. 
Figure 3. Republic of Haiti: Sensitivity Analysis, 2005-25

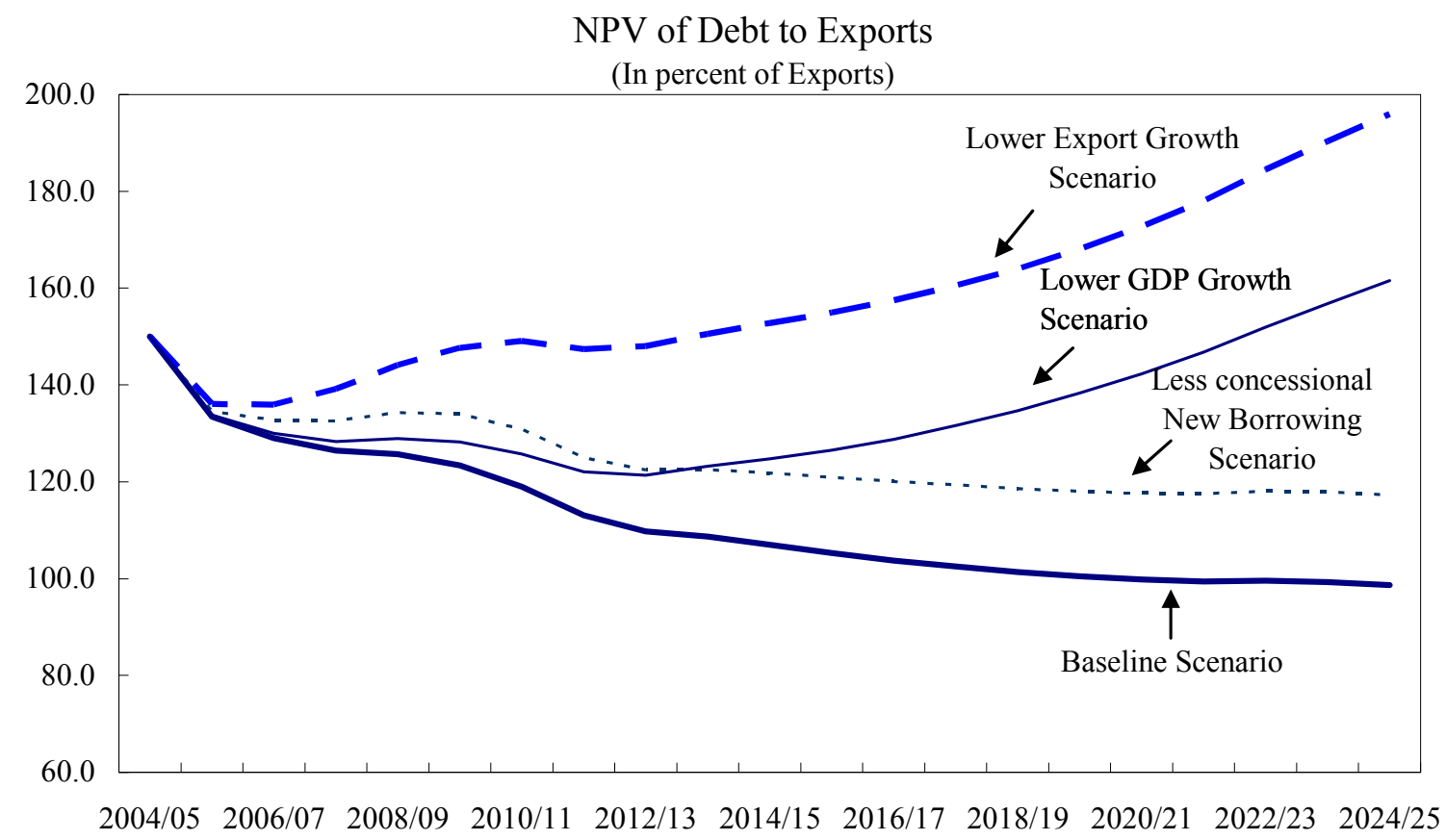

Debt Service to Exports

(In percent of Exports)

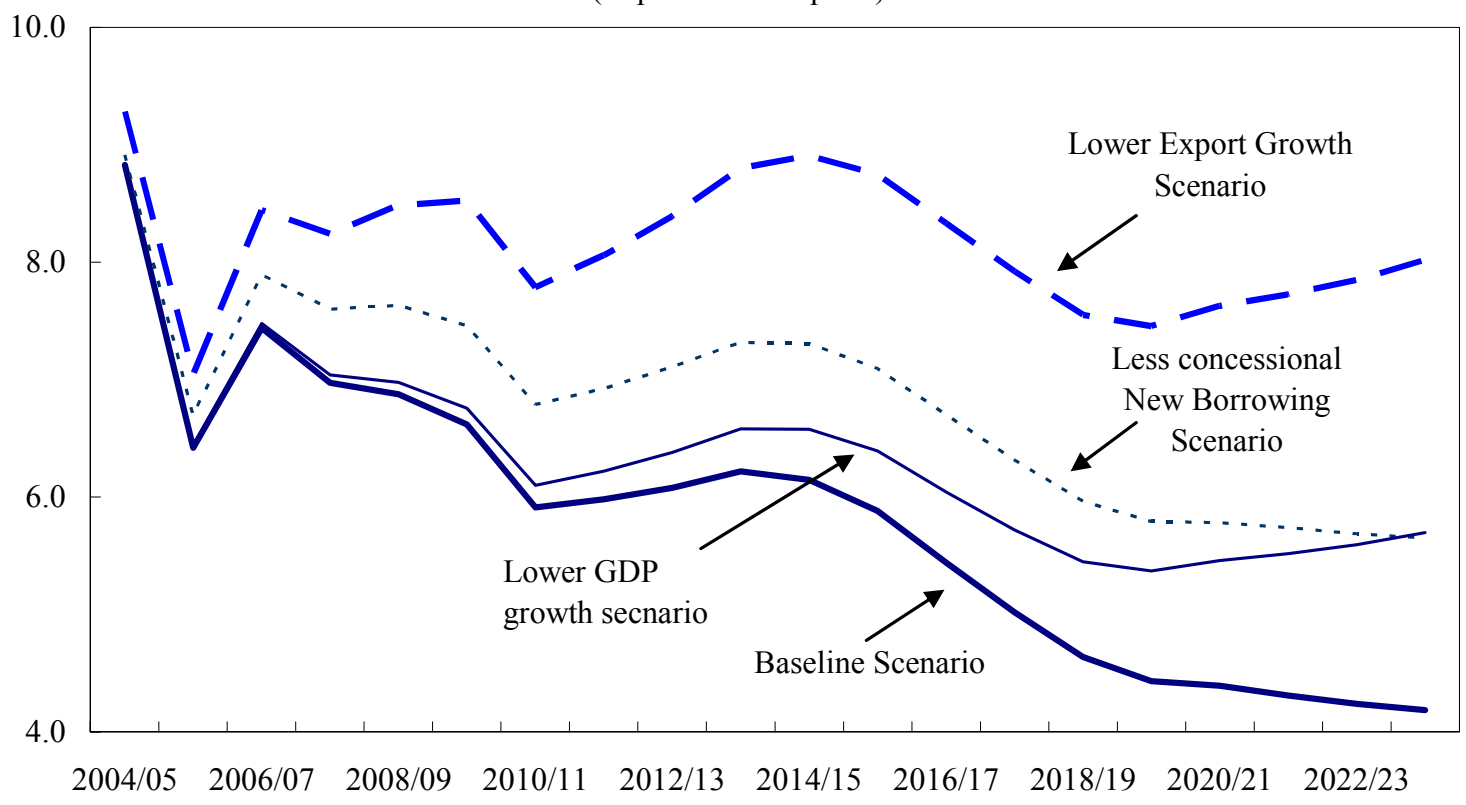

Sources: Haitian authorities and staff estimates and proiections. 
Table A1. Republic of Haiti: Nominal Stock and Net Present Value of Debt at end-September 2005 by Creditor Groups (In million of US\$ unless otherwise specified)

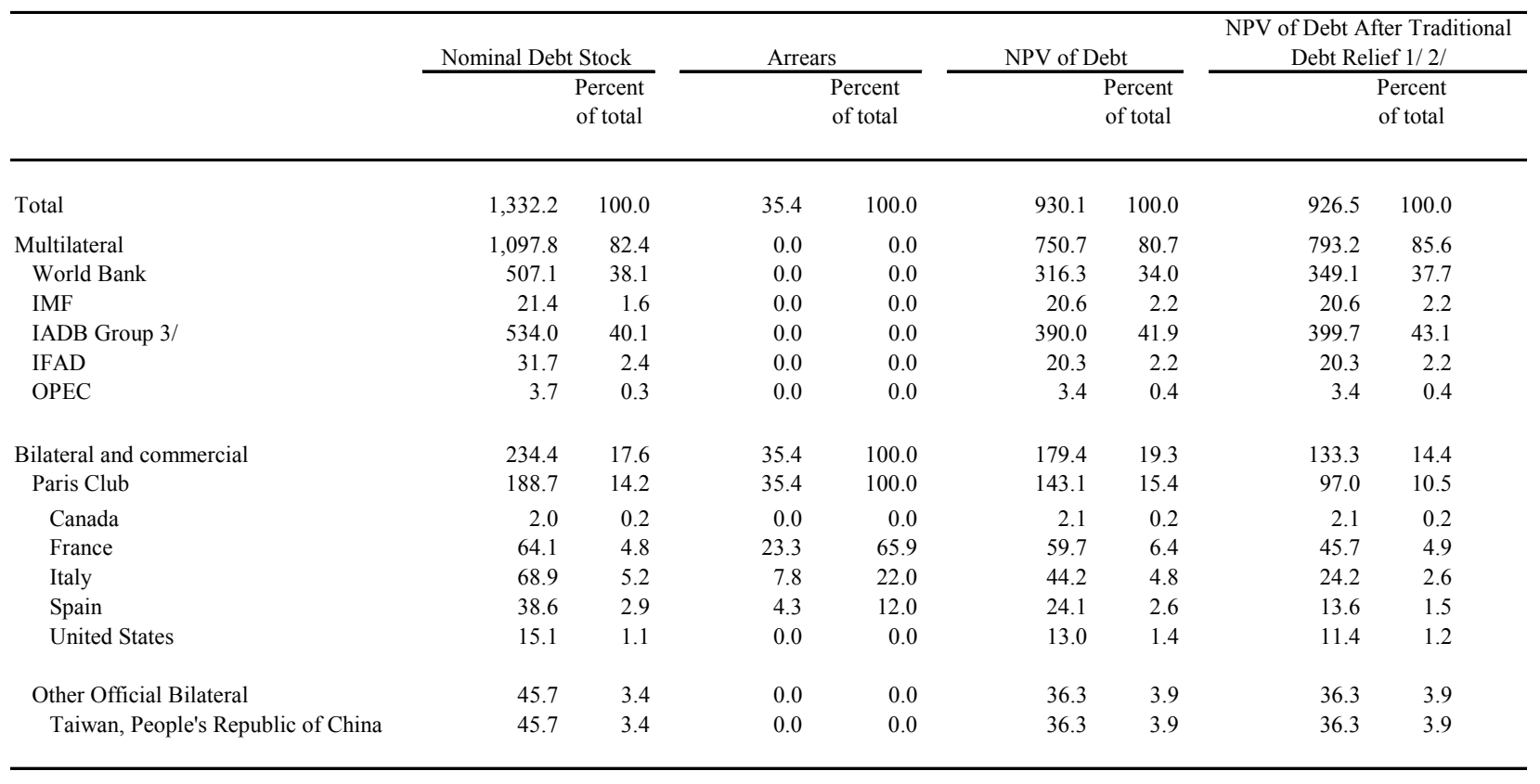

Sources: Haitian authorities; and Fund and Bank staff estimates.

1/ Includes a stock-of-debt operation on Naples terms at end-September 2005; and at least comparable action by other official bilateral and commercial creditors on eligible debt (pre-cutoff and non-ODA)

2/ The increase in the NPV of debt for the IADB Group and the World Bank reflects the inclusion of arrears rescheduling operations in 2003 and 2005 ,

respectively. The concessional element of the rescheduling operation for the IADB Group (US\$9.7 million) and the World Bank (US\$32.8 million) are assumed as part of their HIPC relief effort.

3/ The IADB Group used concessional resources from its Fund for Special Operations (FSO). 
Table A2. Republic of Haiti: HIPC Initiative-- Assistance Under a Proportional Burden-Sharing Approach 1/2/ (In millions of U.S. dollars, unless otherwise indicated)

\begin{tabular}{|c|c|c|c|c|}
\hline $\begin{array}{l}\text { NPV of debt- } \\
\text { to-exports-target } \\
\text { (in percent) }\end{array}$ & \multicolumn{3}{|c|}{ (In NPV terms at end-September 2005) } & $\begin{array}{c}\text { Common Reduction } \\
\text { Factor } 4 / \\
\text { (Percent) }\end{array}$ \\
\hline \multicolumn{5}{|l|}{ Memorandum items: } \\
\hline NPV of debt $5 /$ & 926 & 133 & 793 & \\
\hline Paris Club creditors & 97 & & & \\
\hline Current-year exports & 597 & & & \\
\hline NPV of debt-to-exports ratio 6/ & 176 & & & \\
\hline
\end{tabular}

Sources: Haitian authorities and staff estimates and projections.

1/ The proportional burden sharing approach is described in "HIPC Initiative--Estimated Costs and Burden Sharing Approaches", July 1997.

2/ Includes a hypothetical stock-of-debt operation on Naples terms (end-September 2005) and comparable treatment by other official bilateral creditors.

3/ Includes all official bilateral creditors.

4/ Each creditor's NPV reduction in percent of its exposure at the decision point.

5/ Based on end-September 2005 data after full application of traditional debt relief mechanisms.

6/ Based on the three-year export average (backward-looking average, i.e., 2005-03). Note that this includes the impact of the concessional

rescheduling of arrears by the World Bank and the IADB Group. 
Table A3. Republic of Haiti: Discount and Exchange Rate Assumptions at End-September 2005

\begin{tabular}{|c|c|c|}
\hline Currency Name & $\begin{array}{c}\text { Discount Rate } 1 / \\
\text { (In percent per annum) }\end{array}$ & $\begin{array}{c}\text { Exchange Rate 2/ } \\
\text { (Currency per U.S. dollar) }\end{array}$ \\
\hline Canadian Dollar & 4.80 & 1.16 \\
\hline Danish Kroner & 4.06 & 6.20 \\
\hline Euro & 4.11 & 0.83 \\
\hline Great Britain Sterling & 5.51 & 0.57 \\
\hline Haitian Gourde (USD equivalent) $3 /$ & 5.05 & 1.00 \\
\hline Japanese Yen & 1.85 & 113.15 \\
\hline Norwegian Kroner & 4.21 & 6.54 \\
\hline Special Drawing Rights & 4.35 & 0.69 \\
\hline Swedish Kroner & 4.21 & 7.75 \\
\hline Swiss Franc & 2.82 & 1.29 \\
\hline United States Dollar & 5.05 & 1.00 \\
\hline Venezuelan Bolivar & 4.35 & 2147 \\
\hline \multicolumn{3}{|l|}{ Memorandum item: } \\
\hline Paris Club cutoff date & October 1,1993 & \\
\hline
\end{tabular}

Sources: OECD; and IMF, International Financial Statistics .

$1 /$ The discount rates used are the average commercial interest reference rates over the six-month period prior to end-September 2005, i.e., the end of the period for which actual debt and export data are available.

2/ The exchange rates are expressed as national currency per U.S. dollar at end-September 2005.

3/ Principal and interest payments are made in Haitian Gourde. However, the amounts to be repaid are denominated in U.S.

dollar. 
Table A4. Republic of Haiti: External Debt Service, 2006-2025 1/

\begin{tabular}{|c|c|c|c|c|c|c|c|c|c|c|c|c|c|c|c|c|c|c|c|c|c|c|}
\hline \multirow[b]{2}{*}{ Before traditional debt relief } & $2005 / 06$ & & 2008/09 & \multicolumn{3}{|c|}{$2009 / 10 \quad 2010 / 11 \quad 2011 / 12$} & \multicolumn{3}{|c|}{$2012 / 13 \quad 2013 / 14 \quad 2014 / 15$} & \multicolumn{2}{|c|}{$2015 / 16 \quad 2016 / 17$} & \multicolumn{2}{|c|}{$2017 / 18 \quad 2018 / 19$} & \multicolumn{2}{|c|}{$2019 / 20 \quad 2020 / 21$} & $2021 / 22$ & \multicolumn{3}{|c|}{$\begin{array}{lllll}2022 / 23 & 2023 / 24 \quad 2024 / 25 \\
\end{array}$} & \multicolumn{2}{|c|}{\begin{tabular}{cc}
\multicolumn{2}{c}{ Averages } \\
$200515 / 16-$ \\
$2014 / 15$ & $2015-16425$
\end{tabular}} \\
\hline & & & & & & & & & & & & & & & & & & & & & & \\
\hline $\begin{array}{l}\text { Total } \\
\text { Existing debt } 2 /\end{array}$ & & $\begin{array}{l}63.2 \\
61.1\end{array}$ & $\begin{array}{l}67.9 \\
64.3\end{array}$ & $\begin{array}{l}78.7 \\
68.4\end{array}$ & $\begin{array}{l}77.7 \\
65.5\end{array}$ & $\begin{array}{l}75.3 \\
61.3\end{array}$ & $\begin{array}{l}71.4 \\
61.4\end{array}$ & $\begin{array}{l}77.0 \\
60.8\end{array}$ & $\begin{array}{l}83.6 \\
60.7\end{array}$ & $\begin{array}{l}91.6 \\
61.9\end{array}$ & $\begin{array}{l}96.8 \\
62.6\end{array}$ & $\begin{array}{l}99.2 \\
61.6\end{array}$ & $\begin{array}{l}98.9 \\
60.5\end{array}$ & $\begin{array}{l}96.8 \\
57.3\end{array}$ & $\begin{array}{l}95.8 \\
54.4\end{array}$ & $\begin{array}{l}98.5 \\
52.6\end{array}$ & $\begin{array}{l}104.7 \\
51.9\end{array}$ & $\begin{array}{r}110.3 \\
51.5\end{array}$ & $\begin{array}{c}116.3 \\
50.5\end{array}$ & $\begin{array}{l}123.0 \\
49.1\end{array}$ & $\begin{array}{l}74.6 \\
62.5\end{array}$ & $\begin{array}{c}10.0 \\
55.2 \\
5.2\end{array}$ \\
\hline Multilateral & 49.9 & 51.4 & 54.5 & 58.1 & 54.8 & 50.6 & 49.8 & 49.1 & 48.9 & 50.2 & 50.8 & 49.8 & 48.8 & 47.4 & 46.2 & 45.5 & 44.7 & 43.9 & 42.5 & 41.3 & 51.7 & 46.1 \\
\hline $\begin{array}{l}\text { World Bank Group } \\
\text { IMF }\end{array}$ & $\begin{array}{c}17.3 \\
50\end{array}$ & $\begin{array}{r}18.3 \\
28\end{array}$ & $\begin{array}{r}18.5 \\
43\end{array}$ & $\begin{array}{c}18.8 \\
77\end{array}$ & $\begin{array}{c}19.7 \\
3.8\end{array}$ & 20.0 & 19.9 & 19.8 & 19.7 & $\begin{array}{r}20.9 \\
00\end{array}$ & $\begin{aligned} 22.2 \\
00\end{aligned}$ & $\begin{array}{r}22.3 \\
00\end{array}$ & 22.2 & 22.0 & 21.9 & 21.7 & 21.6 & 21.4 & 21.3 & 20.8 & 19.3 & $\begin{array}{c}21.7 \\
21.7 \\
00\end{array}$ \\
\hline $\begin{array}{l}\text { IAFB Group } \\
\text { IADB }\end{array}$ & $\begin{array}{r}5.0 \\
25.5\end{array}$ & $\begin{array}{r}28.8 \\
28.4\end{array}$ & 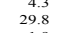 & $\begin{array}{r}7.7 \\
29.6\end{array}$ & $\begin{array}{r}3.8 \\
29.4\end{array}$ & $\begin{array}{l}0.0 \\
29.0\end{array}$ & $\begin{array}{r}0.0 \\
28.6\end{array}$ & $\begin{array}{r}0.0 \\
28.0\end{array}$ & $\begin{array}{r}0.0 \\
27.9\end{array}$ & $\begin{array}{l}0.0 \\
28.0\end{array}$ & $\begin{array}{l}0.0 \\
27.3\end{array}$ & $\begin{array}{l}0.0 \\
26.2\end{array}$ & $\begin{array}{l}0.0 \\
25.4\end{array}$ & $\begin{array}{l}0.0 \\
24.1\end{array}$ & $\begin{array}{r}0.0 \\
23.1\end{array}$ & $\begin{array}{l}0.0 \\
22.5\end{array}$ & $\begin{array}{l}0.0 \\
21.9\end{array}$ & $\begin{array}{r}0.0 \\
21.3\end{array}$ & $\begin{array}{l}0.0 \\
20.0\end{array}$ & $\begin{array}{c}0.0 \\
19.3\end{array}$ & $\begin{array}{l}2.44 \\
28.4\end{array}$ & $\begin{array}{r}0.0 \\
23.1\end{array}$ \\
\hline $\begin{array}{l}\text { OOthers } \\
\text { Official bilateral }\end{array}$ & $\begin{array}{l}2.0 \\
9.6\end{array}$ & $\begin{array}{l}2.0 \\
9.8\end{array}$ & $\begin{array}{l}1.9 \\
9.8\end{array}$ & $\begin{array}{r}2.0 \\
10.2\end{array}$ & $\begin{array}{r}2.0 \\
10.7\end{array}$ & $\begin{array}{r}1.6 \\
10.8\end{array}$ & $\begin{array}{r}1.3 \\
11.5\end{array}$ & $\begin{array}{r}1.3 \\
11.7\end{array}$ & $\begin{array}{r}1.3 \\
11.8\end{array}$ & $\begin{array}{r}1.3 \\
11.7\end{array}$ & $\begin{array}{r}1.3 \\
11.8\end{array}$ & $\begin{array}{r}1.3 \\
11.9\end{array}$ & $\begin{array}{r}1.3 \\
11.7\end{array}$ & $\begin{array}{l}1.3 \\
9.9\end{array}$ & $\begin{array}{l}1.3 \\
8.2\end{array}$ & $\begin{array}{l}1.3 \\
7.1\end{array}$ & 1.2 & $\begin{array}{l}1.2 \\
7.6\end{array}$ & $\begin{array}{l}1.2 \\
8.2\end{array}$ & $\begin{array}{l}1.2 \\
7.8\end{array}$ & $\begin{array}{l}1.7 \\
10.8\end{array}$ & $\begin{array}{l}1.3 \\
9.1\end{array}$ \\
\hline $\begin{array}{l}\text { Paris Club } \\
\text { Non Plub }\end{array}$ & $\begin{array}{l}7.0 \\
7.0\end{array}$ & $\begin{array}{l}7.1 \\
7.1\end{array}$ & $\begin{array}{l}7.0 \\
7.2\end{array}$ & $\begin{array}{r}7.3 \\
30 \\
30\end{array}$ & $\begin{array}{r}7.4 \\
3.3 \\
3.3\end{array}$ & $\begin{array}{l}7.5 \\
3.5 \\
32\end{array}$ & $\begin{array}{l}7.7 \\
3.7\end{array}$ & $\begin{array}{l}7.9 \\
37\end{array}$ & $\begin{array}{r}8.1 \\
3.1\end{array}$ & $\begin{array}{r}8.1 \\
3.1 \\
36\end{array}$ & $\begin{array}{r}8.3 \\
35\end{array}$ & $\begin{array}{l}8.4 \\
8.4\end{array}$ & $\begin{array}{l}8.3 \\
8.3\end{array}$ & $\begin{array}{l}6.6 \\
3.6 \\
3.3\end{array}$ & $\begin{array}{l}6.2 \\
6.2 \\
20\end{array}$ & $\begin{array}{l}5.5 \\
16\end{array}$ & $\begin{array}{l}5.6 \\
1.6\end{array}$ & $\begin{array}{l}6.1 \\
6.1\end{array}$ & $\begin{array}{l}6.5 \\
6.5\end{array}$ & $\begin{array}{l}7.0 \\
7.0 \\
08\end{array}$ & $\begin{array}{l}7.5 \\
3.5 \\
32\end{array}$ & $\begin{array}{l}9.1 \\
6.9 \\
2.3\end{array}$ \\
\hline $\begin{array}{l}\text { Non Paris Club } \\
\text { New debt } 3 /\end{array}$ & $\begin{array}{l}2.6 \\
0.6\end{array}$ & $\begin{array}{l}2.7 \\
2.0\end{array}$ & $\begin{array}{l}2.6 \\
3.6\end{array}$ & $\begin{array}{l}30.0 \\
10.3\end{array}$ & $\begin{array}{r}3.3 \\
12.2\end{array}$ & $\begin{array}{l}3.2 .2 \\
13.9\end{array}$ & $\begin{array}{l}3.8 \\
10.1\end{array}$ & $\begin{array}{l}3.7 \\
16.2\end{array}$ & $\begin{array}{r}3.7 \\
22.9\end{array}$ & $\begin{array}{l}3.6 \\
29.7\end{array}$ & $\begin{array}{r}3.5 \\
34.2\end{array}$ & $\begin{array}{r}3.5 \\
37.6 \\
\end{array}$ & $\begin{array}{r}3.44 \\
38.4\end{array}$ & $\begin{array}{r}3.3 \\
39.5 \\
\end{array}$ & $\begin{array}{r}2.0 \\
41.4\end{array}$ & $\begin{array}{l}1.6 \\
45.9\end{array}$ & $\begin{array}{l}1.6 \\
52.8\end{array}$ & $\begin{aligned} 1.5 \\
58.8\end{aligned}$ & $\begin{array}{l}1.5 \\
65.8\end{array}$ & $\begin{array}{l}0.8 \\
74.0\end{array}$ & $\begin{array}{l}3.22 \\
12.2\end{array}$ & $\begin{array}{r}2.33 \\
48.8\end{array}$ \\
\hline $\begin{array}{l}\text { Debs tervicic to exports rataio } \\
\text { Debb servive to revenue ratio }\end{array}$ & $\begin{array}{r}9.1 \\
14.0\end{array}$ & $\begin{array}{r}8.8 \\
12.2\end{array}$ & $\begin{array}{r}8.7 \\
11.7\end{array}$ & $\begin{array}{r}9.2 \\
12.0\end{array}$ & $\begin{array}{r}8.3 \\
10.5\end{array}$ & $\begin{array}{l}7.4 \\
9.0\end{array}$ & $\begin{array}{l}6.5 \\
7.8\end{array}$ & $\begin{array}{l}6.6 \\
7.7\end{array}$ & $\begin{array}{l}6.6 \\
7.6\end{array}$ & $\begin{array}{l}6.8 \\
7.6\end{array}$ & $\begin{array}{l}6.7 \\
7.4\end{array}$ & $\begin{array}{l}6.4 \\
6.9\end{array}$ & $\begin{array}{l}5.9 \\
6.3\end{array}$ & $\begin{array}{l}5.4 \\
5.7\end{array}$ & $\begin{array}{l}5.0 \\
5.2\end{array}$ & $\begin{array}{l}4.8 \\
4.9\end{array}$ & $\begin{array}{l}4.7 \\
4.7\end{array}$ & $\begin{array}{l}4.6 \\
4.6\end{array}$ & $\begin{array}{l}4.5 \\
4.4\end{array}$ & $\begin{array}{l}4.4 \\
4.3\end{array}$ & $\begin{array}{r}7.8 \\
10.0\end{array}$ & $\begin{array}{l}5.2 \\
5.4\end{array}$ \\
\hline After traditional debt relief 4 / & & & & & & & & & & & & & & & & & & & & & & \\
\hline $\begin{array}{l}\text { Total } \\
\text { Evisting debt } 2 /\end{array}$ & $\begin{array}{l}57.4 \\
569\end{array}$ & $\begin{array}{l}60.5 \\
585\end{array}$ & $\begin{array}{l}65.2 \\
616\end{array}$ & 76.4 & $\begin{array}{l}75.3 \\
603.2\end{array}$ & $\begin{array}{l}72.8 \\
589\end{array}$ & $\begin{array}{l}69.1 \\
590\end{array}$ & $\begin{array}{l}74.6 \\
584\end{array}$ & $\begin{array}{l}80.8 \\
559\end{array}$ & $\begin{array}{l}89.1 \\
594\end{array}$ & $\begin{array}{l}94.4 \\
602\end{array}$ & $\begin{array}{l}97.0 \\
594\end{array}$ & $\begin{array}{l}97.1 \\
587\end{array}$ & $\begin{array}{l}95.3 \\
558 \\
558\end{array}$ & $\begin{array}{l}94.7 \\
53.3\end{array}$ & $\begin{array}{r}98.4 \\
55.5\end{array}$ & $\begin{array}{c}105.4 \\
526\end{array}$ & $\begin{array}{l}110.9 \\
552\end{array}$ & $\begin{array}{r}116.9 \\
511\end{array}$ & $\begin{array}{l}123.5 \\
495\end{array}$ & $\begin{array}{l}72.1 \\
600\end{array}$ & $\begin{array}{c}103.3 \\
54.5 \\
10.5\end{array}$ \\
\hline & & $\begin{array}{l}58.5 \\
51.4\end{array}$ & & & $\begin{array}{l}63.2 \\
54.8\end{array}$ & 58.96 & 49.8 & 49.1 & 48.9 & & & & & 47.4 & 46.2 & 45.5 & 44.7 & 43.9 & & & $\begin{array}{l}60.0 \\
51.7\end{array}$ & \\
\hline World Bank Group & 17.3 & $\begin{array}{l}31.4 \\
18.3 \\
3\end{array}$ & $\begin{array}{l}54.5 \\
18.5 \\
-50\end{array}$ & $\begin{array}{l}18.8 \\
18.1 \\
-10\end{array}$ & $\begin{array}{l}34.8 \\
19.7\end{array}$ & 20.0 & $\begin{array}{l}49.9 \\
19.9 \\
-10\end{array}$ & 19.8 & 19.7 & 20.9 & 22.2 & 22.3 & 22.2. & 22.0 & 21.9 & 21.7 & 21.6 & $\begin{array}{l}21.4 \\
21.4\end{array}$ & 21.3 & 20.8 & $\begin{array}{l}31.3 \\
19.3\end{array}$ & $\begin{array}{l}46.1 \\
21.7\end{array}$ \\
\hline $\begin{array}{l}\text { IMF } \\
\text { IADB Group }\end{array}$ & $\begin{array}{r}5.0 \\
25.5\end{array}$ & $\begin{array}{r}2.8 \\
28.4\end{array}$ & $\begin{array}{r}4.3 \\
29.8\end{array}$ & $\begin{array}{r}7.7 \\
29.6\end{array}$ & $\begin{array}{r}3.8 \\
29.4\end{array}$ & $\begin{array}{l}0.0 \\
29.0\end{array}$ & $\begin{array}{r}0.0 \\
28.6\end{array}$ & $\begin{array}{l}0.0 \\
28.0\end{array}$ & $\begin{array}{r}0.0 \\
27.9\end{array}$ & $\begin{array}{l}0.0 \\
28.0\end{array}$ & $\begin{array}{r}0.0 \\
27.3\end{array}$ & $\begin{array}{l}0.0 \\
26.2\end{array}$ & $\begin{array}{r}0.0 \\
25.4\end{array}$ & $\begin{array}{l}0.0 \\
24.1\end{array}$ & $\begin{array}{l}0.0 \\
23.1\end{array}$ & $\begin{array}{l}0.0 \\
22.5\end{array}$ & $\begin{array}{l}0.0 \\
21.9\end{array}$ & $\begin{array}{r}0.0 \\
21.3\end{array}$ & $\begin{array}{l}0.0 \\
20.0\end{array}$ & $\begin{array}{l}0.0 \\
19.3\end{array}$ & $\begin{array}{l}2.44 \\
28.4\end{array}$ & $\begin{array}{l}0.0 \\
23.1\end{array}$ \\
\hline $\begin{array}{l}\text { OOthers } \\
\text { Official bilateral }\end{array}$ & $\begin{array}{l}2.0 \\
7.0\end{array}$ & $\begin{array}{l}2.0 \\
7.1\end{array}$ & $\begin{array}{l}1.9 \\
7.1\end{array}$ & ${ }_{8.0}^{2.0}$ & $\begin{array}{l}2.0 \\
8.3\end{array}$ & $\begin{array}{l}1.6 \\
8.3\end{array}$ & $\begin{array}{l}1.3 \\
9.1\end{array}$ & $\begin{array}{l}1.3 \\
9.3 \\
9\end{array}$ & $\begin{array}{l}1.3 \\
9.0\end{array}$ & & $\begin{array}{l}1.3 \\
9.4\end{array}$ & $\begin{array}{l}1.3 \\
9.7\end{array}$ & $\begin{array}{l}1.3 \\
9.9\end{array}$ & $\begin{array}{l}1.3 \\
8.4\end{array}$ & & & $\begin{array}{l}1.2 \\
7.9\end{array}$ & $\begin{array}{l}1.2 \\
82\end{array}$ & $\begin{array}{l}1.2 \\
85\end{array}$ & $\begin{array}{l}1.2 \\
82\end{array}$ & $\begin{array}{l}1.7 \\
82\end{array}$ & $\begin{array}{l}1.3 \\
8.4\end{array}$ \\
\hline $\begin{array}{l}\text { Official intateral } \\
\text { Paris Club }\end{array}$ & $\begin{array}{l}3.0 \\
4.4\end{array}$ & $\begin{array}{l}7.1 \\
4.4\end{array}$ & $\begin{array}{l}7.1 \\
4.5\end{array}$ & $\begin{array}{l}8.0 \\
5.0 \\
30\end{array}$ & $\begin{array}{c}8.3 \\
5.0 \\
3.3\end{array}$ & $\begin{array}{c}8.3 \\
5,1 \\
3.2\end{array}$ & $\begin{array}{c}9.1 \\
5.3 \\
3.3\end{array}$ & $\begin{array}{c}9.3 \\
5.5 \\
3.7\end{array}$ & $\begin{array}{c}9.0 \\
5.3 \\
3.3\end{array}$ & $\begin{array}{l}9.2 \\
5.6 \\
3.6\end{array}$ & $\begin{array}{c}9.4 \\
5.9 \\
3.5\end{array}$ & $\begin{array}{r}9.7 \\
6.2 \\
3.5\end{array}$ & $\begin{array}{c}9.9 \\
6.5 \\
.4\end{array}$ & $\begin{array}{l}8.4 \\
5.1\end{array}$ & $\begin{array}{l}7.1 \\
5.1 \\
.1\end{array}$ & $\begin{array}{l}7.0 \\
5.4 \\
-4\end{array}$ & $\begin{array}{l}7.9 \\
6.3 \\
-3\end{array}$ & $\begin{array}{l}8.2 \\
6.7\end{array}$ & $\begin{array}{l}8.5 \\
7.1\end{array}$ & $\begin{array}{l}8.2 \\
7.5\end{array}$ & $\begin{array}{l}8.2 \\
5.0\end{array}$ & $\begin{array}{l}8.4 \\
6.2 \\
6.3\end{array}$ \\
\hline $\begin{array}{l}\text { New dent } 3 / \text { ars Club } \\
\text { New }\end{array}$ & $\begin{array}{l}2.6 \\
0.6\end{array}$ & $\begin{array}{l}2.7 \\
2.0\end{array}$ & $\begin{array}{l}2.6 \\
3.6\end{array}$ & $\begin{array}{l}30.0 \\
10.3\end{array}$ & $\begin{array}{r}3.3 \\
12.2\end{array}$ & $\begin{array}{l}3.2 .2 \\
13.9\end{array}$ & $\begin{array}{l}3.8 \\
10.1\end{array}$ & $\begin{array}{l}3.7 \\
16.2\end{array}$ & $\begin{array}{r}3.7 \\
22.9\end{array}$ & $\begin{array}{l}39.6 \\
29.7\end{array}$ & $\begin{array}{r}3.5 \\
34.2\end{array}$ & $\begin{array}{r}37.5 \\
37.6\end{array}$ & $\begin{array}{r}3.4 \\
38.4\end{array}$ & $\begin{array}{r}3.3 \\
39.5\end{array}$ & $\begin{array}{r}2.0 \\
41.4\end{array}$ & $\begin{array}{l}1.6 \\
45.9\end{array}$ & $\begin{array}{c}1.6 \\
52.8\end{array}$ & $\begin{array}{r}1.5 \\
58.8\end{array}-x-8$ & $\begin{array}{l}1.5 \\
65.8\end{array}$ & $\begin{array}{r}0.8 \\
74.0\end{array}$ & $\begin{array}{l}3.22 \\
12.2\end{array}$ & $\begin{array}{r}2.33 \\
48.8\end{array}$ \\
\hline $\begin{array}{l}\text { Debt service to exports ratio } \\
\text { Debt service to revenuu ratio }\end{array}$ & $\begin{array}{r}8.7 \\
13.4\end{array}$ & $\begin{array}{r}8.4 \\
11.7\end{array}$ & $\begin{array}{r}8.3 \\
11.2\end{array}$ & $\begin{array}{r}8.9 \\
11.7\end{array}$ & $\begin{array}{r}8.1 \\
10.2\end{array}$ & $\begin{array}{l}7.1 \\
8.7\end{array}$ & $\begin{array}{l}6.3 \\
7.5\end{array}$ & $\begin{array}{l}6.4 \\
7.4\end{array}$ & $\begin{array}{l}6.4 \\
7.4\end{array}$ & $\begin{array}{l}6.6 \\
7.4\end{array}$ & $\begin{array}{l}6.5 \\
7.2\end{array}$ & $\begin{array}{l}6.2 \\
6.8\end{array}$ & $\begin{array}{l}5.8 \\
6.2\end{array}$ & $\begin{array}{l}5.3 \\
5.6\end{array}$ & $\begin{array}{l}4.9 \\
5.1\end{array}$ & $\begin{array}{l}4.7 \\
4.9\end{array}$ & $\begin{array}{l}4.7 \\
4.8\end{array}$ & $\begin{array}{l}4.6 \\
4.6\end{array}$ & $\begin{array}{l}4.5 \\
4.5\end{array}$ & $\begin{array}{l}4.5 \\
4.3 \\
\mathrm{C}\end{array} \mathrm{C}$ & $\begin{array}{l}7.5 \\
0.7\end{array}$ & $\begin{array}{l}5.2 \\
5.4\end{array}$ \\
\hline After HIPC assistance 5/ & & & & & & & & & & & & & & & & & & & & & & \\
\hline$\underset{\substack{\text { Total } \\
\text { Existing det }}}{ }$ & $\begin{array}{c}58.2 \\
57.6\end{array}$ & $\begin{array}{l}46.3 \\
44.3 \\
4\end{array}$ & $\begin{array}{l}58.2 \\
54.7\end{array}$ & $\begin{array}{l}59.6 \\
49.3\end{array}$ & $\begin{array}{l}64.3 \\
52.1\end{array}$ & $\begin{array}{l}67.7 \\
53.8\end{array}$ & $\begin{array}{l}64.7 \\
54.6\end{array}$ & $\begin{array}{l}70.2 \\
539\end{array}$ & $\begin{array}{l}76.5 \\
536\end{array}$ & $\begin{array}{l}84.1 \\
544-1\end{array}$ & $\begin{array}{l}89.1 \\
549\end{array}$ & $\begin{array}{l}91.4 \\
53.8\end{array}$ & 90.9 & 90.1 & 89.4 & 91.9 & $\begin{array}{l}97.9 \\
45.1\end{array}$ & 103.2 & 109.0 & 115.9 & $\begin{array}{c}65.0 \\
558\end{array}$ & $\begin{array}{l}96.9 \\
48.1\end{array}$ \\
\hline $\begin{array}{l}\text { Existung debt 2/ } \\
\text { Multilateral }\end{array}$ & $\begin{array}{l}57.6 \\
49.9\end{array}$ & $\begin{array}{l}44.3 \\
41.0\end{array}$ & $\begin{array}{c}54.7 \\
50.0\end{array}$ & $\begin{array}{l}49.3 \\
41.6\end{array}$ & $\begin{array}{l}52.1 \\
44.1\end{array}$ & $\begin{array}{l}53.8 \\
45.8\end{array}$ & $\begin{array}{l}54.6 \\
46.2\end{array}$ & $\begin{array}{l}53.9 \\
45.5\end{array}$ & $\begin{array}{l}53.6 \\
45.3\end{array}$ & $\begin{array}{l}54.4 \\
46.6\end{array}$ & $\begin{array}{l}54.9 \\
47.3\end{array}$ & $\begin{array}{l}53.8 \\
46.4\end{array}$ & $\begin{array}{l}52.5 \\
45.5\end{array}$ & $\begin{array}{l}50.6 \\
44.3\end{array}$ & $\begin{array}{l}48.0 \\
43.2\end{array}$ & $\begin{array}{l}46.0 \\
42.6\end{array}$ & $\begin{array}{l}45.1 \\
41.9 \\
4\end{array}$ & $\begin{array}{l}{ }_{41.2}^{44.4} \\
-1\end{array}$ & $\begin{array}{l}43.3 \\
40.0\end{array}$ & ${ }_{38.8}^{41.9}$ & $\begin{array}{l}52.8 \\
45.6\end{array}$ & \\
\hline $\begin{array}{l}\text { World Bank Group } \\
\text { IMF } 3\end{array}$ & $\begin{array}{c}17.3 \\
50\end{array}$ & $\begin{array}{c}11.7 \\
22\end{array}$ & $\begin{array}{r}18.5 \\
36\end{array}$ & $\begin{array}{l}9.4 \\
59\end{array}$ & $\begin{array}{r}14.5 \\
3.5\end{array}$ & $\begin{aligned} 20.0 \\
0.0\end{aligned}$ & $\begin{array}{r}19.9 \\
0.9\end{array}$ & $\begin{array}{l}19.8 \\
00\end{array}$ & $\begin{array}{c}19.7 \\
00\end{array}$ & $\begin{aligned} 20.9 \\
0.0\end{aligned}$ & $\begin{aligned} 22.2 \\
00\end{aligned}$ & $\begin{array}{r}22.3 \\
00\end{array}$ & $\begin{aligned} 22.2 \\
00\end{aligned}$ & $\begin{aligned} 22.0 \\
00\end{aligned}$ & $\begin{array}{r}21.9 \\
00\end{array}$ & $\begin{aligned} 21.7 \\
00\end{aligned}$ & $\begin{array}{c}21.6 \\
00\end{array}$ & $\begin{aligned} 21.4 \\
00\end{aligned}$ & $\begin{aligned} 21.3 \\
00\end{aligned}$ & $\begin{array}{c}20 \\
0\end{array}$ & $\begin{array}{c}17.2 \\
20\end{array}$ & $\begin{array}{l}\begin{array}{l}21.7 \\
0.0\end{array} \\
0.0\end{array}$ \\
\hline $\begin{array}{l}\text { IMF3 } \\
\text { IADB Group }\end{array}$ & $\begin{array}{r}5.0 \\
25.5\end{array}$ & 25.22 & $\begin{array}{r}3.60 \\
26.0\end{array}$ & 25.8 & $\begin{array}{l}3.3 \\
25.6\end{array}$ & 25.3 & $\begin{array}{r}0.0 \\
24.9\end{array}$ & $\begin{array}{r}0.0 \\
24.4\end{array}$ & 24.3 & 24.4 & 23.8 & 22.8 & $\begin{array}{l}0.0 \\
22.1\end{array}$ & $\begin{array}{l}0.0 \\
21.0\end{array}$ & $\begin{array}{l}0.0 \\
20.1\end{array}$ & $\begin{array}{c}0.0 \\
19.6\end{array}$ & $\begin{array}{l}0.0 \\
19.1\end{array}$ & $\begin{array}{l}0.0 \\
18.5\end{array}$ & $\begin{array}{l}0.0 \\
17.5\end{array}$ & $\begin{array}{l}0.0 \\
16.8\end{array}$ & $\begin{array}{r}2.0 . \\
25.1\end{array}$ & $\begin{array}{l}0.0 \\
20.1 \\
2.3\end{array}$ \\
\hline $\begin{array}{l}\text { Others } \\
\text { Official bilateral }\end{array}$ & $\begin{array}{l}2.0 \\
7.8\end{array}$ & $\begin{array}{l}2.0 \\
3.3 \\
-3\end{array}$ & $\begin{array}{l}1.9 \\
4.7\end{array}$ & $\begin{array}{l}0.5 \\
7.7 \\
-1\end{array}$ & $\begin{array}{l}0.5 \\
8.1\end{array}$ & $\begin{array}{l}0.6 \\
8.0\end{array}$ & $\begin{array}{l}1.3 \\
8.5\end{array}$ & $\begin{array}{l}1.3 \\
8.4\end{array}$ & $\begin{array}{l}1.3 \\
8.3\end{array}$ & $\begin{array}{l}1.3 \\
7.8\end{array}$ & $\begin{array}{l}1.3 \\
7.7\end{array}$ & $\begin{array}{l}1.3 \\
7.4\end{array}$ & $\begin{array}{l}1.3 \\
7.0\end{array}$ & $\begin{array}{l}1.3 \\
6.3 \\
-3\end{array}-1$ & $\begin{array}{l}1.3 \\
4.8\end{array}$ & $\begin{array}{l}1.3 \\
3.4\end{array}$ & $\frac{1.2}{3.2}$ & $\frac{1.2}{3.3}$ & $\begin{array}{l}1.2 \\
3.3\end{array}$ & $\frac{1.2}{3.1}$ & $\begin{array}{l}1.3 \\
7.3\end{array}$ & $\begin{array}{l}1.3 \\
4.9\end{array}$ \\
\hline 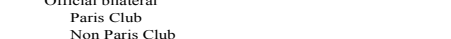 & $\begin{array}{l}1.8 \\
5.2\end{array}$ & $\begin{array}{l}3.3 \\
1.1 \\
., 3\end{array}$ & $\begin{array}{l}4.9 \\
2.4\end{array}$ & $\begin{array}{l}7.9 \\
5.2\end{array}$ & $\begin{array}{l}8.1 \\
5.3 \\
.3\end{array}$ & $\begin{array}{l}8.0 \\
5.3 \\
.7\end{array}$ & $\begin{array}{l}8.3 \\
5.3\end{array}$ & $\begin{array}{c}8.4 \\
5.3 \\
5.1\end{array}$ & $\begin{array}{l}8.3 \\
5.2\end{array}$ & $\begin{array}{l}7.8 \\
4.8\end{array}$ & 4.7 & $\begin{array}{l}7.4 \\
4.5 \\
4.9\end{array}$ & $\begin{array}{l}7.0 \\
4.1 \\
.0\end{array}$ & $\begin{array}{l}6.3 \\
3.5 \\
3.8\end{array}$ & $\begin{array}{l}4.8 \\
3.1\end{array}$ & $\begin{array}{l}3.4 \\
2.0\end{array}$ & $\begin{array}{l}3.2 \\
1.9 \\
1.9\end{array}$ & $\begin{array}{l}3.3 \\
2.0 \\
.3\end{array}$ & $\begin{array}{l}3.3 \\
2.0 \\
.3\end{array}$ & $\begin{array}{l}3.1 \\
2.4\end{array}$ & $\begin{array}{l}7.3 \\
4.5\end{array}$ & $\begin{array}{l}4.9 \\
19 \\
19\end{array}$ \\
\hline $\begin{array}{l}\text { Commercial } \\
\text { Cow tuo }\end{array}$ & 0.0 & o.0 & 0.0 & 0.0 & $\begin{array}{l}2.8 \\
0.0 \\
.102\end{array}$ & 0.0 & 0.0 & $\begin{array}{ll}3.1 \\
0.0\end{array}$ & 0.1. & $\begin{array}{lll}3.0 \\
0.0\end{array}$ & $\begin{array}{l}3.0 \\
0.0\end{array}$ & 0.0 & 0.0 & 0.0 & 0.0 & $\begin{array}{l}1.4 \\
0.0\end{array}$ & $\begin{array}{l}1.3 \\
0.0\end{array}$ & $\begin{array}{l}1.3 \\
0.0\end{array}-0$ & $\begin{array}{l}1.3 \\
0.0\end{array}$ & $\begin{array}{l}0.7 \\
0.0\end{array}$ & $\begin{array}{l}2.7 \\
0.0\end{array}$ & 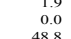 \\
\hline New debt is/ & 0.6 & & 3.6 & & & & & & & & & 37.6 & 38.4 & 39.3 & & & & 58.8 & 65.8 & & 12.2 & 48.8 \\
\hline $\begin{array}{l}\text { Detb service to exports ratio a after HIPC Casistance } \\
\text { Debt service to revenue ratio after HIPC assistance }\end{array}$ & $\begin{array}{c}8.8 \\
13.6\end{array}$ & $\begin{array}{l}6.4 \\
9.0\end{array}$ & $\begin{array}{c}7.4 \\
10.0\end{array}$ & $\begin{array}{l}7.0 \\
9.1\end{array}$ & $\begin{array}{l}6.9 \\
8.7\end{array}$ & $\begin{array}{l}6.6 \\
8.1\end{array}$ & $\begin{array}{l}5.9 \\
7.0\end{array}$ & $\begin{array}{l}6.0 \\
7.0\end{array}$ & $\begin{array}{l}6.1 \\
7.0\end{array}$ & $\begin{array}{l}6.2 \\
7.0\end{array}$ & $\begin{array}{l}6.1 \\
6.8\end{array}$ & $\begin{array}{l}5.9 \\
6.4\end{array}$ & $\begin{array}{l}5.4 \\
5.8\end{array}$ & $\begin{array}{l}5.0 \\
5.3\end{array}$ & 4.8 & 童.4 & $\begin{array}{l}4.4 \\
4.4\end{array}$ & $\begin{array}{l}4.3 \\
4.3\end{array}$ & $\begin{array}{l}4.2 \\
4.2\end{array}$ & $\begin{array}{l}4.2 \\
4.1\end{array}$ & $\begin{array}{l}6.7 \\
8.6\end{array}$ & 5.1 \\
\hline $\begin{array}{l}\text { Reduction in debt servivec as a result of } \\
\text { HIPC Initititive assistance } 6 \text {. }\end{array}$ & & 14.2 & 6.9 & 16.8 & 11.0 & 5.1 & 4.3 & 4.5 & 4.3 & 5.0 & 5.3 & 5.6 & 6.2 & 5.2 & 5.3 & 6.5 & 7.5 & 7.7 & 7.8 & 7.6 & 8.0 & 6.5 \\
\hline After HIPC and MDRI assistance 7/ & & & & & & & & & & & & & & & & & & & & & & \\
\hline $\begin{array}{l}\text { Total } \\
\text { Existing debt } 22\end{array}$ & $\begin{array}{c}58.2 \\
576\end{array}$ & $\begin{array}{l}46.3 \\
44.3\end{array}$ & $\begin{array}{l}58.2 \\
547\end{array}$ & $\begin{array}{l}50.4 \\
40.0\end{array}$ & $\begin{array}{r}50.0 \\
37.8\end{array}$ & $\begin{array}{l}47.9 \\
339\end{array}$ & $\begin{array}{l}45.0 \\
449\end{array}$ & $\begin{array}{c}50.6 \\
343.3\end{array}$ & 57.1 & $\begin{array}{l}63.6 \\
340\end{array}$ & $\begin{array}{c}67.7 \\
33.5\end{array}$ & 69.8 & 69.4 & $\begin{array}{l}68.8 \\
293 \\
293\end{array}$ & $\begin{array}{l}68.2 \\
269\end{array}$ & $\begin{array}{l}70.9 \\
250\end{array}$ & 77.0 & 82.5 & 88.5 & 96.0 & $\begin{array}{l}52.7 \\
406\end{array}$ & 75.9 \\
\hline $\begin{array}{l}\text { Exisiting debt 2/ } \\
\text { Multilateral }\end{array}$ & $\begin{array}{l}57.6 \\
49.9\end{array}$ & $\begin{array}{l}44.3 \\
41.0\end{array}$ & $\begin{array}{l}54.7 \\
50.0\end{array}$ & $\begin{array}{l}40.0 \\
32.3 \\
32.3\end{array}$ & $\begin{array}{l}\begin{array}{l}37.8 \\
29.7\end{array} \\
-\end{array}$ & $\begin{array}{l}33.9 \\
25.9 \\
250\end{array}$ & $\begin{array}{l}34.9 \\
26.4\end{array}$ & $\begin{array}{l}34.3 \\
25.9\end{array}$ & $\begin{array}{l}34.2 \\
25.8\end{array}$ & $\begin{array}{l}34.0 \\
26.2\end{array}$ & $\begin{array}{l}33.5 \\
25.8\end{array}$ & $\begin{array}{l}32.2 \\
24.8\end{array}$ & $\begin{array}{l}31.1 \\
24.1 \\
24.1\end{array}$ & $\begin{array}{l}29.3 \\
23.0\end{array}$ & $\begin{array}{l}26.9 \\
22.1\end{array}$ & $\begin{array}{l}\begin{array}{l}25.0 \\
21.6\end{array} \\
2.03\end{array}$ & $\begin{array}{l}24.2 \\
21.0\end{array}$ & $\begin{array}{l}\begin{array}{l}23.7 \\
20.5\end{array} \\
\end{array}$ & $\begin{array}{l}\begin{array}{l}22.7 \\
19.4\end{array} \\
\end{array}$ & 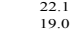 & 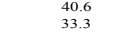 & $\begin{array}{l}27 \\
22\end{array}$ \\
\hline $\begin{array}{l}\text { World Bank Group } \\
\text { IMF } 3 /\end{array}$ & $\begin{array}{c}17.3 \\
5.0\end{array}$ & $\begin{array}{l}11.7 \\
2.2\end{array}$ & $\begin{array}{r}18.5 \\
3.6\end{array}$ & $\begin{array}{l}0.1 \\
5.9 \\
5.9\end{array}$ & $\begin{array}{l}0.1 \\
3.5\end{array}$ & $\begin{array}{l}0.1 \\
0.0\end{array}$ & $\begin{array}{l}0.2 \\
0.0\end{array}$ & $\begin{array}{l}0.2 \\
0.0\end{array}$ & $\begin{array}{l}0.2 \\
0.0\end{array}$ & $\begin{array}{l}0.5 \\
0.0\end{array}$ & $\begin{array}{l}0.7 \\
0.0\end{array}$ & $\begin{array}{l}0.7 \\
0.0\end{array}$ & $\begin{array}{l}0.7 \\
0.0\end{array}$ & $\begin{array}{l}0.7 \\
0.0\end{array}$ & $\begin{array}{l}0.7 \\
0.0\end{array}$ & $\begin{array}{l}0.7 \\
0.0\end{array}$ & $\begin{array}{l}0.7 \\
0.0\end{array}$ & $\begin{array}{l}0.7 \\
0.0\end{array}$ & $\begin{array}{l}0.7 \\
0.0\end{array}$ & $\begin{array}{c}1.0 \\
0.0\end{array}$ & $\begin{array}{l}4.9 \\
20\end{array}$ & $\begin{array}{l}0.7 \\
0.0\end{array}$ \\
\hline IADB Group & 25.5 & 25.2 & 26.0 & 25.8 & $\begin{array}{r}25.6 \\
25.6\end{array}$ & 25.3 & 24.9 & 24.4 & 24.3 & 24.4 & 23.8 & 22.8 & 22.10 & 21.0 & 20.1 & 19.6 & 19.1 & 18.5 & 17.5 & 16.8 & 25.1 & $\begin{array}{c}20.0 \\
13\end{array}$ \\
\hline $\begin{array}{l}\text { Others } \\
\text { Official bilateral }\end{array}$ & $\begin{array}{l}2.0 \\
7.8\end{array}$ & $\begin{array}{l}2.0 \\
3.3\end{array}$ & $\begin{array}{l}1.9 \\
4.7\end{array}$ & $\begin{array}{l}0.5 \\
7.7\end{array}$ & $\begin{array}{l}0.5 \\
8.1\end{array}$ & $\begin{array}{l}0.6 \\
8.0\end{array}$ & $\begin{array}{l}1.3 \\
8.5\end{array}$ & $\begin{array}{l}1.3 \\
8.4\end{array}$ & $\begin{array}{l}1.3 \\
8.3\end{array}$ & $\begin{array}{l}1.3 \\
7.8\end{array}$ & $\begin{array}{l}1.3 \\
7.7\end{array}$ & $\begin{array}{l}1.3 \\
7.4\end{array}$ & $\begin{array}{l}1.3 \\
7.0\end{array}$ & $\begin{array}{l}1.3 \\
6.3 \\
-3\end{array}-1$ & $\begin{array}{l}1.3 \\
4.8\end{array}$ & $\begin{array}{l}1.3 \\
3.4\end{array}$ & $\begin{array}{l}1.2 \\
3.2\end{array}$ & $\begin{array}{l}1.2 \\
3.3\end{array}$ & ${ }_{3.3}^{1.2}$ & ${ }_{3.1}^{1.2}$ & $\begin{array}{l}1.3 \\
7.3\end{array}$ & $\begin{array}{l}1.3 \\
4.9\end{array}$ \\
\hline $\begin{array}{l}\text { Commercial } \\
\text { New debt } 3 /\end{array}$ & $\begin{array}{l}0.0 \\
0.6\end{array}-15$ & $\begin{array}{l}0.0 \\
2.0\end{array}$ & $\begin{array}{l}0.0 \\
3.6\end{array}$ & 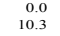 & $\begin{array}{r}0.0 \\
12.2\end{array}$ & $\begin{array}{c}0.0 \\
13.9\end{array}$ & $\begin{array}{l}0.0 \\
10.1\end{array}$ & $\begin{array}{c}0.0 \\
16.2\end{array}$ & $\begin{array}{r}0.0 \\
22.9\end{array}$ & $\begin{aligned} 0.0 \\
29.7\end{aligned}$ & $\begin{array}{l}0.0 \\
34.2\end{array}$ & $\begin{aligned} 0.0 \\
37.6\end{aligned}-10$ & $\begin{array}{l}0.0 \\
38.4\end{array}$ & $\begin{array}{l}0.0 \\
39.5\end{array}$ & $\begin{array}{r}0.0 \\
41.4\end{array}$ & $\begin{aligned} 0.0 \\
45.9\end{aligned}$ & $\begin{array}{l}0.0 \\
52.8\end{array}$ & $\begin{array}{c}0.0 \\
58.8\end{array}$ & $\begin{array}{l}0.0 \\
65.8\end{array}$ & $\begin{array}{l}0.0 \\
74.0\end{array}$ & $\begin{array}{c}0.0 \\
12.2\end{array}$ & $\begin{array}{l}0.0 \\
48.8\end{array}$ \\
\hline $\begin{array}{l}\text { Debt service to exports ratio after HIPC and MDRR assistance } \\
\text { Debt service to reverue ratio after HIPC and MDR assistance }\end{array}$ & $\begin{array}{r}8.8 \\
13.6\end{array}$ & $\begin{array}{l}6.4 \\
9.0\end{array}$ & $\begin{array}{c}7.4 \\
10.0\end{array}$ & $\begin{array}{l}5.9 \\
7.7\end{array}$ & $\begin{array}{l}5.3 \\
6.8\end{array}$ & $\begin{array}{l}4.7 \\
5.7\end{array}$ & $\begin{array}{l}4.1 \\
4.9\end{array}$ & $\begin{array}{l}4.3 \\
5.0\end{array}$ & $\begin{array}{l}4.5 \\
5.2\end{array}$ & $\begin{array}{l}.4 .7 \\
5.3\end{array}$ & $\begin{array}{l}4.7 \\
5.2\end{array}$ & $\begin{array}{l}4.5 \\
4.9\end{array}$ & $\begin{array}{l}4.2 \\
4.4\end{array}$ & $\begin{array}{l}3.8 \\
4.0\end{array}$ & $\begin{array}{l}3.5 \\
3.7\end{array}$ & $\begin{array}{l}3.4 \\
3.5\end{array}$ & $\begin{array}{l}3.5 \\
3.5\end{array}$ & $\begin{array}{l}3.4 \\
3.4\end{array}$ & $\begin{array}{l}3.4 \\
3.4\end{array}$ & $\begin{array}{l}3.5 \\
3.4\end{array}$ & $\begin{array}{l}5.6 \\
7.3\end{array}$ & $\begin{array}{l}3.8 \\
3.9\end{array}$ \\
\hline $\begin{array}{l}\text { Reduction in debt service as a result of } \\
\text { MDRI assistance }\end{array}$ & 0.0 & 0.0 & 0.0 & 9.3 & 14.4 & 19.9 & 19.7 & 19.6 & 19.5 & 20.5 & 21.4 & 21.6 & 21.4 & 21.3 & 21.2 & 21.0 & 20.9 & 20.7 & 20.6 & 19.8 & 12.3 & 21.0 \\
\hline $\begin{array}{l}\text { Memorandum items: } \\
\text { Exports of goods and nonfactor services } 8 / \\
\text { Goverment revenes } 89 \text { a }\end{array}$ & $\begin{array}{l}659.3 \\
4289\end{array}$ & $\begin{array}{l}721.7 \\
721\end{array}$ & 783.1 & 854.8 & 935.8 & $1,023.7$ & 1,005.2. & $1,1773.4$ & $1,259.0$ & $1,352.7$ & $1,449.55$ & $1,554.8$ & $1,669.8$ & $1,795.4$ & $\begin{array}{l}1,9277.8 \\
\end{array}$ & 2, 2,072.1 & $2,229.3$ & 94.4 & 73.9 & $2,769.1$ & 985.9 & $\begin{array}{l}2,043.6 \\
109956\end{array}$ \\
\hline & & & & & & & & $1,004.8$ & 1,0988.4 & & & $1,430.9$ & $1,561.4$ & $1,703.1$ & & & $2,205.3$ & $2,401.9$ & 6.615.3 & & 798.0 & 1,995.6 \\
\hline
\end{tabular}

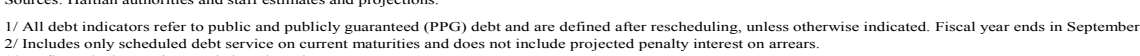

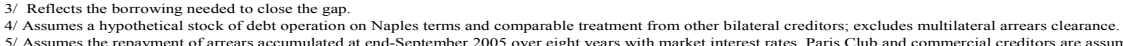

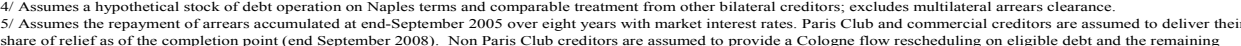

share of relief as of the completion point (end September 2008$)$. Non Paris Club reditors are assumed to provide a Cologne flow rescheduling on eligible debt and the remaining
of the required HIPC assistance is to be delivered at the completion point through a stock of debt operation. Multiliteral creditors are also assumed to provide HIICC debt relief

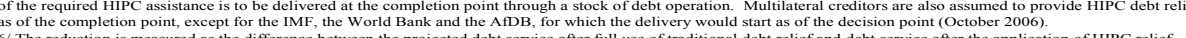

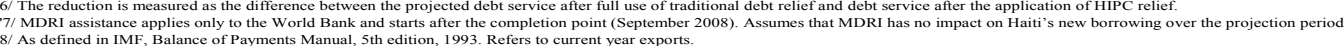

8/ As defined in IMF, Balance of Pagments Manual, Sth edition, 1993. Refers to current year export
$9 /$ Revenues are defined as central government revenues, excluding grants. 
Table A5. Republic of Haiti: Net Present Value of External Debt, 2005-2025 1/

\begin{tabular}{|c|c|c|c|c|c|c|c|c|c|c|c|c|c|c|c|c|c|c|c|c|c|c|c|}
\hline & 200405 & 200506 & $2006 / 07$ & 200708 & $2008 / 09$ & $2009 / 10$ & 2010/11 & 2011/12 & $2012 / 13$ & $2013 / 14$ & 2014/15 & $2015 / 16$ & $2016 / 17$ & $2017 / 18$ & $2018 / 19$ & 2019/20 & 2020/21 & $2021 / 22$ & $2022 / 23$ & $2023 / 24$ & 202425 & $\begin{array}{l}\text { Average } \\
20040105 \text { - } \\
2014115\end{array}$ & $\begin{array}{l}201516-6 \\
202425\end{array}$ \\
\hline \multicolumn{24}{|l|}{ I. After traditional debt-relier $2 / 37$} \\
\hline NPV of oulstanding debt & $\begin{array}{l}884.0 \\
88.0\end{array}-$ & 867.6 & 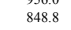 & 826.1 & 797.8 & 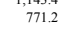 & $\begin{array}{r}7,200.2 \\
747.6\end{array}$ & $\begin{array}{l}7,253.3 \\
722.8\end{array}$ & $\begin{array}{l}7,288.6 \\
697.5\end{array}$ & $\begin{array}{r}1,300.00 \\
671.6\end{array}$ & 642.9 & $\begin{array}{l}6,031.1 \\
612.1\end{array}$ & $\begin{array}{r}3,984.8 \\
580.6\end{array}$ & $\begin{array}{l}7,02.6 .8 \\
548.4\end{array}$ & $\begin{array}{l}7,100.8 \\
517.6\end{array}$ & 487.9 & $\begin{array}{r}9,997.1 \\
457.6\end{array}$ & $\begin{array}{r}2,192.44 \\
425.9\end{array}$ & $\begin{array}{l}2,439.0 \\
393.2\end{array}$ & $\begin{array}{l}2,439.0 \\
360.0\end{array}$ & ${ }_{326.8}^{29.4}$ & 770.7 & $\begin{array}{r}r, 9885.4 \\
471.0\end{array}$ \\
\hline $\begin{array}{l}\text { Official bilateral and commercial } \\
\text { Paris Club }\end{array}$ & $\begin{array}{l}13.3 \\
99.0\end{array}$ & $\begin{array}{l}132.6 \\
99.0\end{array}$ & $\begin{array}{c}131.8 \\
97.1 \\
1.1\end{array}$ & $\begin{array}{l}130.8 \\
97.1\end{array}$ & $\begin{array}{l}129.1 \\
99.6\end{array}$ & $\begin{array}{l}126.8 \\
96.0\end{array}$ & ${ }_{95.3}^{124.4}$ & $\begin{array}{l}121.1 \\
99.3 \\
-10\end{array}$ & $\begin{array}{l}117.6 \\
93.1\end{array}$ & $\begin{array}{l}114.1 \\
92.0\end{array}$ & $\begin{array}{l}110.2 \\
90.7\end{array}$ & $\begin{array}{l}106.0 \\
89.0\end{array}$ & $\begin{array}{l}101.2 \\
86.8\end{array}$ & $\begin{array}{l}96.0 \\
84.3\end{array}$ & $\begin{array}{l}92.0 \\
83.1\end{array}$ & $\begin{array}{l}89.2 \\
81.7\end{array}$ & $\begin{array}{l}86.3 \\
80.1\end{array}$ & $\begin{array}{l}82.3 \\
77.4\end{array}$ & $\begin{array}{l}77.8 \\
74.2\end{array}$ & $\begin{array}{l}72.8 \\
70.5\end{array}$ & $\begin{array}{l}67.8 \\
66.1\end{array}$ & $\begin{array}{l}124.7 \\
95.1\end{array}$ & $\begin{array}{l}87.2 \\
7.3 .3\end{array}$ \\
\hline 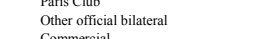 & 36.3 & 35.5 & 34.7 & 33.8 & 32.5 & 30.8 & 29.2 & 26.8 & 24.5 & 22.0 & 19.6 & 17.0 & 14.4 & 11.7 & 9.0 & 7.4 & 6.2 & 4.9 & 3.7 & 2.4 & $\begin{array}{l}60.1 \\
1.7\end{array}$ & 29.6 & 7.8 \\
\hline $\begin{array}{c}\text { Commercial } \\
\text { Multilateral }\end{array}$ & $\begin{array}{r}0.0 \\
750.7\end{array}$ & $\begin{aligned} 0.0 \\
735.0\end{aligned}$ & $\begin{aligned} 0.0 \\
717.1\end{aligned}$ & $\begin{array}{r}0.0 \\
695.2\end{array}$ & $\begin{array}{r}0.0 \\
668.8\end{array}$ & $\begin{array}{l}0.0 \\
644.4\end{array}$ & $\begin{array}{r}0.0 \\
62.2 \\
6\end{array}$ & $\begin{array}{c}0.0 \\
60.7\end{array}$ & $\begin{array}{c}0.0 \\
580.0\end{array}$ & $\begin{aligned} 0.0 \\
557.5\end{aligned}$ & $\begin{array}{c}0.0 \\
532.6\end{array}$ & $\begin{array}{c}0.0 \\
506.1\end{array}$ & $\begin{array}{r}0.0 \\
479.4\end{array}$ & $\begin{array}{r}0.0 \\
452.4\end{array}$ & $\begin{array}{r}0.0 \\
425.6\end{array}$ & $\begin{array}{r}0.0 \\
398.7\end{array}$ & $\begin{aligned} 0.0 \\
371.4\end{aligned}$ & $\begin{array}{r}0.0 \\
343.6\end{array}$ & $\begin{array}{r}0.0 \\
315.3\end{array}$ & $\begin{array}{r}0.0 \\
287.1\end{array}$ & $\begin{array}{r}0.0 \\
258.9\end{array}$ & $\begin{array}{r}0.0 \\
646.0\end{array}$ & $\begin{array}{r}0.0 \\
383.8\end{array}$ \\
\hline NPV of new borrowing & 0.0 & 32.5 & 107.2 & 189.2 & 282.2 & 372.2 & 452.6 & 511.4 & 590.1 & 688.4 & 788.9 & 892.9 & 1004.2 & 1124.3 & 1252.2 & 1390.6 & 1540.1 & 1703.5 & 1890.4 & 2077.6 & 2268.6 & 365.0 & $1,514.4$ \\
\hline \multicolumn{24}{|l|}{$\begin{array}{l}\text { Memorandum items: } \\
\text { NPV of debt-to-exports ratio (percent) 4/ }\end{array}$} \\
\hline 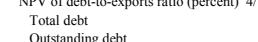 & 168.3 & $\begin{array}{l}152.8 \\
1473\end{array}$ & $\begin{array}{l}145.0 \\
1087\end{array}$ & 140.7 & 137.3 & $\begin{array}{l}133.3 \\
880\end{array}$ & $\begin{array}{l}127.9 \\
707-30\end{array}$ & 121.2 & 117.3 & $\begin{array}{l}115.7 \\
57\end{array}$ & $\begin{array}{ll}113.5 \\
5.0\end{array}$ & $\begin{array}{l}111.2 \\
452\end{array}$ & 109.1 & $\begin{array}{l}107.4 \\
352\end{array}$ & $\begin{array}{l}105.8 \\
{ }_{30}\end{array}$ & 104.5 & $\begin{array}{l}103.4 \\
23.3\end{array}$ & 102.6 & 102.3 & $\begin{array}{l}101.6 \\
1.0\end{array}$ & 100.6 & 133.9 & 104.8 \\
\hline $\begin{array}{l}\mathrm{NPV} \text { of deb-t-o-revenue ratio (percent) } \\
\text { Total debt- }\end{array}$ & & & & & & & & & & & & & & & & & & & & & & & \\
\hline $\begin{array}{l}\text { Iotaldading debt } \\
\text { Oustanding debt }\end{array}$ & $\begin{array}{l}233.1 \\
235.1\end{array}$ & $\begin{array}{l}20.9 .3 \\
202.3\end{array}$ & $\begin{array}{l}78.22 \\
164.4\end{array}$ & 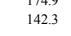 & $\begin{array}{l}762.3 \\
122.1\end{array}$ & $\begin{array}{l}134.8 \\
104.4\end{array}$ & $\begin{array}{l}14.9 .0 \\
89.0\end{array}-1$ & $\begin{array}{l}134.3 \\
78.7\end{array}$ & $\begin{array}{l}628.4 \\
69.4\end{array}$ & $\begin{array}{l}723.8 \\
61.1\end{array}$ & $\begin{array}{c}719.3 \\
53.6\end{array}$ & $\begin{array}{l}74.8 \\
46.7\end{array}$ & $\begin{array}{l}10.8 \\
40.6\end{array}$ & ${ }_{35.1}^{10.1}$ & $\begin{array}{l}703.99 \\
30.4\end{array}$ & $\begin{array}{l}101.2 \\
26.3\end{array}$ & 22.6 & $\begin{array}{l}96.6 \\
19.3\end{array}$ & $\begin{array}{l}93.1 \\
16.4 \\
16.450\end{array}$ & 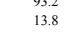 & $\begin{array}{l}91.2 \\
11.5\end{array}$ & $\begin{array}{l}161.2 \\
120.2\end{array}$ & $\begin{array}{l}10.2 \\
26.3\end{array}$ \\
\hline \multicolumn{24}{|c|}{ II. After conditional delivery of enhanced HIPC assistance $5 /$} \\
\hline NPV of total debt & 916.7 & 904.6 & 974.9 & 912.0 & 988.6 & $1,058.6$ & $1,116.4$ & $1,150.8$ & $1,204.7$ & $1,277.3$ & $1,350.1$ & $1,424.8$ & $1,506.4$ & $1,596.8$ & $1,695.6$ & $1,806.1$ & $1,928.5$ & $2,064.4$ & $2,223.3$ & $2,382.2$ & $2,545.1$ & 1,077.7 & 1.917.3. \\
\hline $\begin{array}{l}\text { NPV of outstanding debt } \\
\text { Offifial bilatera and commercial }\end{array}$ & $\begin{array}{l}916.7 \\
179.4\end{array}$ & $\begin{array}{l}872.1 \\
151.1\end{array}$ & $\begin{array}{l}867.7 \\
159\end{array}$ & 722.8 & $\begin{array}{l}706.4 \\
89.9\end{array}$ & $\begin{array}{l}686.4 \\
85.8\end{array}$ & $\begin{array}{c}663.8 \\
8.18\end{array}$ & $\begin{array}{c}639.4 \\
770\end{array}$ & $\begin{array}{l}614.6 \\
72.2\end{array}$ & $\begin{array}{r}58.9 \\
6.2\end{array}$ & $\frac{561.2}{62.4}$ & $\begin{array}{r}531.8 \\
57.6\end{array}$ & $\begin{array}{l}502.2 \\
559\end{array}$ & $\begin{array}{r}472.5 \\
48.3\end{array}$ & 443.3 & $\begin{array}{c}415.5 \\
44.4\end{array}$ & $\begin{array}{c}388.4 \\
339\end{array}$ & $\begin{array}{l}360.9 \\
38.5\end{array}$ & $\begin{array}{r}332.8 \\
37.0\end{array}$ & $\begin{array}{l}304.7 \\
3.3 .3\end{array}$ & $\begin{array}{l}27.5 \\
3.8\end{array}$ & $\begin{array}{l}712.7 \\
101.3\end{array}$ & $\begin{array}{l}402.9 \\
42.9\end{array}$ \\
\hline Paris Club & 143.1 & 121.1 & $\begin{array}{l}125.9 \\
125.7\end{array}$ & 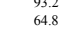 & $\begin{array}{l}89.4 \\
62.4\end{array}$ & $\begin{array}{l}\begin{array}{l}85.8 \\
59.8\end{array} \\
-\end{array}$ & $\begin{array}{l}8.8 \\
57.2\end{array}-12$ & 54.4 & $\begin{array}{l}22.2 \\
51.6\end{array}$ & $\begin{array}{l}76.2 \\
48.6\end{array}$ & 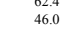 & $\begin{array}{l}37.6 \\
43.3\end{array}$ & $\begin{array}{l}32.9 \\
40.7\end{array}$ & 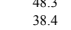 & $\begin{array}{l}44.2 \\
36.6\end{array}$ & 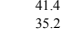 & 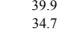 & $\begin{array}{l}38.5 \\
34.4\end{array}$ & $\begin{array}{l}37.0 \\
33.9\end{array}$ & $\begin{array}{l}35.3 \\
33.4\end{array}$ & $\begin{array}{l}33.8 \\
32.4\end{array}$ & $\begin{array}{c}10.13 \\
75.9\end{array}$ & 32.9 \\
\hline Other official bilateral & 36.3 & 29.9 & 29.2 & 28.4 & 27.4 & 26.0 & 24.6 & 22.6 & 20.6 & 18.6 & 16.5 & 14.3 & 12.1 & 9.9 & 7.6 & 6.3 & 5.2 & 4.2 & 3.1 & 2.0 & 1.4 & 25.5 & 6.6 \\
\hline $\begin{array}{c}\text { Commercial } \\
\text { Multilateral } \\
\text { nats }\end{array}$ & $\begin{array}{r}0.0 \\
7373\end{array}$ & 0.0 & $\begin{array}{r}0.0 \\
710^{2}\end{array}$ & 0.0 & 0.0 & 0.0 & 50.0 & 0.0 & 0.0 & 0.0 & $\begin{array}{c}0.0 \\
0.08\end{array}$ & 0.0 & $\begin{array}{r}0.0 \\
4493\end{array}$ & 0.0 & $\begin{array}{l}0.0 \\
302\end{array}$ & 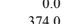 & $\begin{array}{l}0.0 \\
3484\end{array}$ & $=0.0$ & $\begin{array}{c}0.0 \\
20.8\end{array}$ & $\begin{array}{c}0.0 \\
2632\end{array}$ & 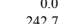 & 0.0 & $\begin{array}{r}0.0 \\
3600\end{array}$ \\
\hline $\begin{array}{l}\text { Muntuatalal } \\
\text { NPV of new borrowing }\end{array}$ & $\begin{array}{c}73.3 \\
0.0\end{array}$ & 32.5 & $\begin{array}{l}712.8 \\
107.2\end{array}$ & $\begin{array}{l}629.6 \\
189.2\end{array}$ & $\begin{array}{l}682.2 \\
282.2\end{array}$ & $\begin{array}{l}600.6 \\
372.2\end{array}$ & 452.6 & $\begin{array}{l}562.4 \\
511.4\end{array}$ & $\begin{array}{l}52.4 \\
590.1\end{array}$ & $\begin{array}{l}521.7 \\
688.4\end{array}$ & $\begin{array}{ll}498.9 \\
788\end{array}$ & $\begin{array}{l}47.2 \\
892.9\end{array}$ & $\begin{array}{r}499.3 \\
1004.2\end{array}$ & $\begin{array}{r}424.2 \\
1124.3\end{array}$ & $\begin{array}{r}399.2 \\
1252.2\end{array}$ & $\begin{array}{r}374.0 \\
1390.6\end{array}$ & $\begin{array}{c}344.4 \\
1540.1\end{array}$ & $\begin{array}{r}322.4 \\
1703.5\end{array}$ & $\begin{array}{r}299.8 \\
1890.4\end{array}$ & $\begin{array}{r}2067.3 \\
2077.6\end{array}$ & $\begin{aligned} 2427.7 \\
2268.6\end{aligned}$ & $\begin{array}{l}\begin{array}{l}611.4 \\
365.0\end{array} \\
3\end{array}$ & $\begin{array}{l}3,560.0 \\
1,54.4\end{array}$ \\
\hline \multicolumn{24}{|c|}{ III. After unconditional delivery of enhanced HIPC assistance $6 /$} \\
\hline NPV of total debt & 787.9 & 786.1 & 850.8 & 912.0 & 988.6 & $1,058.6$ & $1,116.4$ & 1,150.8. & $1,204.7$ & $1,277.3$ & $1,350.1$ & $1,424.8$ & $1,506.4$ & $1,596.8$ & $1,695.6$ & $1,806.1$ & $1,928.5$ & $2,064.4$ & $2,223.3$ & $2,382.2$ & $2,545.1$ & 1,043.9 & 1,917.3 \\
\hline 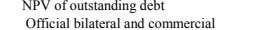 & & $\begin{array}{l}753.6 \\
926\end{array}$ & $\begin{array}{l}743.6 \\
036\end{array}$ & $\begin{array}{c}722.8 \\
93.2 \\
-12\end{array}$ & $\begin{array}{l}706,4 \\
809\end{array}$ & $\begin{array}{l}686.4 \\
858\end{array}$ & $\begin{array}{c}663.8 \\
818\end{array}$ & $\begin{array}{c}639.4 \\
770\end{array}$ & $\begin{array}{l}614.6 \\
722\end{array}$ & 588.9 & 561.2 & $\begin{array}{r}531.8 \\
576\end{array}$ & $\begin{array}{c}502.2 \\
529\end{array}$ & $\begin{array}{l}472.5 \\
483\end{array}$ & $\begin{array}{l}443.3 \\
442\end{array}$ & $\begin{array}{l}415.5 \\
414\end{array}$ & $\begin{array}{l}388.4 \\
390 \\
390\end{array}$ & $\begin{array}{r}360.9 \\
385\end{array}$ & $\begin{array}{r}332.8 \\
370\end{array}$ & $\begin{array}{l}304.7 \\
353\end{array}$ & $\begin{array}{l}276.5 \\
338\end{array}$ & 679.0 & $\begin{array}{l}402.9 \\
429\end{array}$ \\
\hline 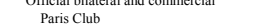 & $\begin{array}{c}713.4 \\
82.5\end{array}$ & $\begin{array}{l}2, .6 \\
62.7\end{array}$ & ${ }_{64.4}^{39.6}$ & $\frac{69.2}{64.8}$ & ${ }_{62.4}^{8.8}$ & 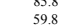 & $\begin{array}{l}81.8 \\
57.2\end{array}$ & 54.4 & $\begin{array}{l}21.2 . \\
51.6\end{array}$ & $\begin{array}{l}67.2 \\
48.6\end{array}$ & $\begin{array}{l}\begin{array}{l}62.4 \\
46.0\end{array} \\
4\end{array}$ & $\begin{array}{l}57.6 \\
43.3\end{array}$ & $\begin{array}{l}52.9 \\
40.7\end{array}$ & 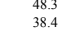 & $\begin{array}{l}44.2 \\
36.6\end{array}$ & 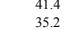 & $\begin{array}{l}339.9 \\
34.7\end{array}$ & $\begin{array}{l}38.5 \\
34.4\end{array}$ & $\begin{array}{l}37.0 \\
33.9\end{array}$ & 33..3 & $\begin{array}{l}33.8 \\
32.4\end{array}$ & $\begin{array}{l}8.4 .4 \\
59.5\end{array}$ & 36.3 \\
\hline Other official bilateral & 30.9 & 29.9 & 29.2 & $\begin{array}{lll}28.4 \\
28.4\end{array}$ & $\begin{array}{l}27.4 \\
27.4\end{array}$ & $\begin{array}{l}23,0.0 \\
26.0\end{array}$ & 24.6 & 22.6 & 20.6 & 18.6 & 16.5 & 14.3 & 12.1 & 9.9 & 7.6 & $\begin{array}{r}3.2 .3 \\
6.3\end{array}$ & 5.2 & 4.2 & 3.1 & 2.0 & 1.4 & 25.0 & 6.6 \\
\hline $\begin{array}{c}\text { Commercial } \\
\text { Multilateral }\end{array}$ & $\begin{array}{l}0.0 \\
6746\end{array}$ & $\begin{array}{r}0.0 \\
60.0\end{array}$ & $\begin{aligned} 0.0 \\
6500\end{aligned}$ & $\begin{array}{r}0.0 \\
6206\end{array}$ & $\begin{array}{r}0.0 \\
6166\end{array}$ & $\begin{array}{c}0.0 \\
6006\end{array}$ & $\begin{array}{r}0.0 \\
582 .\end{array}$ & $\begin{array}{r}0.0 \\
5624\end{array}$ & $\begin{array}{r}0.0 \\
5424\end{array}$ & $\begin{array}{r}0.0 \\
5217\end{array}$ & $\begin{aligned} 0.0 \\
4098\end{aligned}$ & $\begin{aligned} 0.0 \\
4772\end{aligned}$ & 0.0 & $\begin{aligned} 0.0 \\
4.222\end{aligned}$ & $\begin{aligned} 0.0 \\
3092\end{aligned}$ & $\begin{array}{r}0.0 \\
3740\end{array}$ & $\begin{array}{r}0.0 \\
3484\end{array}$ & 0.0 & 0.0 & 0.0 & 0.0 & 0.0 & 0.0 \\
\hline $\begin{array}{l}\text { Mutrlateral } \\
\text { Wort Bank }\end{array}$ & $\begin{array}{l}674.6 \\
298.2\end{array}$ & $\begin{array}{l}661.0 \\
294,2 \\
24.0\end{array}$ & $\begin{array}{l}650.0 \\
2956 \\
29.6\end{array}$ & $\begin{array}{l}629.6 \\
202.2 \\
20.6\end{array}$ & 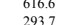 & $\begin{array}{l}6006 \\
202.3 \\
29.3\end{array}$ & $\begin{array}{l}582.1 \\
285.3 \\
285\end{array}$ & $\begin{array}{l}562.4 \\
2781\end{array}$ & $\begin{array}{l}52.24 \\
{ }_{2706}\end{array}$ & $\begin{array}{l}521.7 \\
262\end{array}$ & $\begin{array}{l}498.8 \\
2536 \\
253\end{array}$ & $\begin{array}{l}4742 \\
2427\end{array}$ & 年49.3 & $\begin{array}{l}4_{242.2} \\
{ }_{21202}\end{array}$ & $\begin{array}{l}392.2 \\
2069\end{array}$ & $\begin{array}{l}37.0 \\
1922\end{array}$ & $\begin{array}{l}348.4 \\
1810\end{array}$ & $\begin{array}{l}32.4 \\
164\end{array}$ & $\begin{array}{l}2958 \\
153\end{array}$ & $\begin{array}{l}20.33 \\
138.8\end{array}$ & $\begin{array}{l}242.7 \\
{ }_{21241}\end{array}$ & 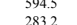 & $\begin{array}{l}360.0 \\
185.9\end{array}$ \\
\hline IADB Group & 343.5 & 333.9 & 324.2 & 313.3 & $\begin{array}{l}290.1 \\
302.1\end{array}$ & 290.5 & 278.8 & 266.9 & 255.0 & 242.6 & 229.5 & 216.5 & 203.8 & 191.2 & 179.2 & 167.5 & 155.8 & 144.0 & 132.3 & ${ }_{121.1}^{10.1}$ & 110.0 & 2089.1 & $\begin{array}{l}18.9 \\
162.1\end{array}$ \\
\hline IMF & 17.8 & 13.6 & 12.0 & 8.9 & 3.4 & 0.0 & 0.0 & 0.0 & 0.0 & 0.0 & 0.0 & 0.0 & 0.0 & 0.0 & 0.0 & 0.0 & 0.0 & 0.0 & 0.0 & 0.0 & 0.0 & 5.1 & 0.0 \\
\hline $\begin{array}{l}\text { Other mulltitatral } \\
\mathrm{NPV} \text { of new borrowing }\end{array}$ & $\begin{array}{r}20.5 \\
0.0\end{array}$ & $\begin{array}{l}19.4 \\
32.5\end{array}$ & $\begin{array}{l}18.3 \\
107.2\end{array}$ & $\begin{array}{l}17.1 \\
189.2\end{array}$ & $\begin{array}{l}1774 \\
282.2\end{array}$ & $\begin{array}{r}177.7 \\
372.2\end{array}$ & $\begin{array}{r}179 \\
452.6\end{array}$ & $\begin{array}{l}117.4 \\
511.4\end{array}$ & $\begin{array}{r}16.8 \\
590.1\end{array}$ & $\begin{aligned} 16.2 \\
688.4\end{aligned}$ & $\begin{array}{r}15.6 \\
788.9\end{array}$ & $\begin{array}{r}15.0 \\
892.9\end{array}$ & $\begin{array}{r}14.4 \\
1004.2\end{array}$ & $\begin{array}{r}13.7 \\
1124.3\end{array}$ & $\begin{array}{r}13.11 \\
1252.2\end{array}$ & $\begin{array}{r}12.4 \\
1390.6\end{array}$ & $\begin{array}{c}11.7 \\
1540.1\end{array}$ & $\begin{array}{r}10.9 \\
1703.5\end{array}$ & $\begin{array}{l}18.2 \\
180.4\end{array}$ & $\begin{array}{r}90.4 \\
2077.6\end{array}$ & $\begin{array}{r}8.6 \\
2268.6\end{array}$ & $\begin{array}{r}17.7 \\
3650\end{array}$ & $\begin{array}{r}11.9 \\
1.5144\end{array}$ \\
\hline \multirow{2}{*}{\multicolumn{24}{|c|}{$\begin{array}{l}\text { Memorandum items: } \\
\text { NPV of deb-to-exports ratio }\end{array}$}} \\
\hline & & & & & & & & & & & & & & & & & & & & & & & \\
\hline very & $\begin{array}{l}\begin{array}{l}77.5 \\
150.0\end{array} \\
\end{array}$ & 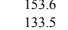 & $\begin{array}{l}\begin{array}{l}147.8 \\
129.0\end{array} \\
-\end{array}$ & $\begin{array}{l}126.4 \\
126.4\end{array}$ & $\begin{array}{l}\begin{array}{l}125.7 \\
125.7\end{array} \\
\end{array}$ & 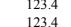 & $\begin{array}{l}\begin{array}{l}119.0 \\
119.0\end{array} \\
\end{array}$ & $\begin{array}{l}\begin{array}{l}113.0 \\
113.0\end{array} \\
10\end{array}$ & $\begin{array}{l}109.8 \\
1098\end{array}$ & $\begin{array}{l}108.6 \\
1086\end{array}$ & $\begin{array}{l}10770 \\
1070\end{array}$ & $\begin{array}{l}105.2 \\
1052\end{array}$ & $\begin{array}{l}103.7 \\
1037\end{array}$ & $\begin{array}{l}102.5 \\
1025 \\
\end{array}$ & $\begin{array}{l}1013 \\
1013 \\
103.1\end{array}$ & $\begin{array}{l}100.5 \\
1005\end{array}$ & $\begin{array}{l}99.8 \\
99.8\end{array}$ & $\begin{array}{l}99.4 \\
994.4\end{array}$ & $\begin{array}{l}99.6 \\
996\end{array}$ & $\begin{array}{l}99.3 \\
993.3 \\
993\end{array}$ & $\begin{array}{l}98.7 \\
987 \\
987\end{array}$ & $\begin{array}{l}128.1 \\
1223\end{array}$ & $\begin{array}{l}101.0 \\
1010\end{array}$ \\
\hline & $\begin{array}{l}130.0 \\
174.5\end{array}$ & $\begin{array}{l}738.1 \\
148.1\end{array}$ & $\begin{array}{l}131.6 \\
131.6\end{array}$ & $\begin{array}{l}10.4 \\
100.2\end{array}$ & 89.8 & $\begin{array}{l}82.4 \\
80.0\end{array}$ & 70.8 & 62.8 & 56.0 & $\begin{array}{l}700.0 \\
50.1\end{array}$ & 44.5 & ${ }_{30.3}$ & $\begin{array}{l}30.46 \\
34.6\end{array}$ & 30.3 & 26.5 & 23.1 & 20.1 & $\begin{array}{l}179.4 \\
17.4\end{array}$ & $\begin{array}{l}39.6 \\
14.9\end{array}$ & 12.7 & 10.7 & ${ }_{91.7} 2.3$ & $\begin{array}{r}10.0 \\
23.0\end{array}$ \\
\hline $\begin{array}{l}\text { NPV of deb-t-torevenue ratio (percent) } \\
\text { Total debt }\end{array}$ & 243.8 & & 188.8 & 157.1 & 151.3 & 143.3 & 133.0 & 125,3 & 11999 & 1163 & 112.5 & 108.7 & 105.3 & 1023 & 99.6 & 97.3 & 95.3 & 93.6 & 92.6 & 91.1 & 89.4 & 154.7 & 97.5 \\
\hline Total debt, assuming full delivery & & & & & & & & & & & 112.5 & & & & & & 95.3 & & & & 89.4 & & 97.5 \\
\hline Outstanding dect & 243.8 & 203.3 & 168.1 & 124.5 & 108.1 & 92.9 & 79.1 & 69.6 & 61.2 & 53.6 & 46.8 & 40.6 & 35.1 & 30.3 & 26.0 & 22.4 & 19.2 & 16.4 & 13.9 & 11.6 & 9.7 & 113.7 & 22.5 \\
\hline \multicolumn{24}{|l|}{ IV. After conditional delivery of enhar } \\
\hline NPV of total debt & 916.7 & 904.6 & 974.9 & 634.4 & 708.0 & 779.9 & 845.2 & 887.3 & 949.0 & $1,029.8$ & $1,112.0$ & $1,197.6$ & $1,290.7$ & $1,393.0$ & $1,504.1$ & $1,627.3$ & $1,762.8$ & $1,912.2$ & $2,085.2$ & $2,258.6$ & $2,436.0$ & 885.6 & $1,746.8$ \\
\hline NPV of outstanding debt & & 872.1 & & & & & & & 3589 & 341.4 & 323.2 & $\begin{array}{c}304.7 \\
576\end{array}$ & & $\begin{array}{r}268.7 \\
483\end{array}$ & 251.9 & & 222.7 & 208.8 & & 181.1 & & & 232.3 \\
\hline 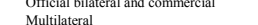 & 179.4 373 & $\begin{array}{l}151.1 \\
7210 \\
7210\end{array}$ & $\begin{array}{l}1349 \\
7128\end{array}$ & 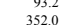 & $\begin{array}{c}39.8 \\
3360 \\
330\end{array}$ & & & $\begin{array}{l}270.8 \\
2988\end{array}$ & 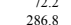 & $\frac{6.2}{27.2}$ & ${ }^{62} 200$ & $\begin{array}{l}3576 \\
2470\end{array}$ & & 年3 & $\begin{array}{l}{ }_{24.2} \\
2077\end{array}$ & $\begin{array}{l}\text { chi.4 } \\
1952\end{array}$ & $\begin{array}{l}3399 \\
182\end{array}$ & 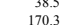 & 年, 150 & 染, 353 & $\begin{array}{l}33.8 \\
1325 \\
\end{array}$ & $\begin{array}{l}10.33 \\
4113 \\
413\end{array}$ & ${ }_{12.9}^{429}$ \\
\hline World Bank & 31.03 30.3 & $\begin{array}{l}321.0 \\
306.8\end{array}$ & $\begin{array}{l}32.88 \\
308.7\end{array}$ & $\begin{array}{c}32.2 .7 \\
12.7\end{array}$ & $\begin{array}{c}350.0 \\
13.1\end{array}$ & ${ }_{13.6} 2.9$ & ${ }_{14.1}^{10.8}$ & 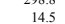 & ${ }_{14.9}^{28.8}$ & 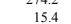 & $\begin{array}{l}20.6 \\
15.6\end{array}$ & ${ }_{15.5}^{24.0}$ & 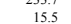 & 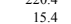 & 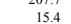 & 列.4 & $\begin{array}{l}15.13 \\
15.3\end{array}$ & 15.3 .3 & 15.3. & $\begin{array}{l}15.2 .2 \\
15.2\end{array}$ & 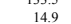 & & $\begin{array}{r}189.4 \\
15.3\end{array}-30$ \\
\hline 3 Group & 383.7 & 376.0 & 368.3 & 313.3 & 302.1 & 290.5 & 278.8 & 266.9 & 255.0 & 242.6 & 229.5 & 216.5 & 203.8 & 191.2 & 179.2 & 167.5 & 155.8 & 144.0 & 132.3 & 121.1 & & 300.6 & 162.1 \\
\hline & & & 13.9 & & & & & & & 0.0 & 0.0 & 0.0 & & & & & & & & 0.0 & & & ${ }_{0.0}^{0.0}-2-3-3-0$ \\
\hline $\begin{array}{l}\text { Ohter multlateral } \\
\text { NPV of new borrowing }\end{array}$ & $\begin{array}{r}23.8 \\
0.0\end{array}$ & $\begin{array}{l}22.8 \\
32.5 \\
2\end{array}$ & $\begin{array}{l}21.9 \\
107.2\end{array}$ & $\begin{array}{l}189.2 \\
189.2\end{array}$ & $\begin{array}{l}18.2 .2 \\
282\end{array}$ & 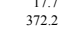 & $\begin{array}{r}1799 \\
452.6\end{array}$ & $\begin{array}{c}11.4 \\
51.4\end{array}$ & $\begin{array}{l}16.8 \\
590.1\end{array}$ & $\begin{array}{l}16.2 \\
688.4\end{array}$ & $\begin{array}{r}15.6 \\
788.9\end{array}$ & $\begin{aligned} 15.0 \\
892.9\end{aligned}$ & $\begin{array}{r}14.4 \\
1004.2\end{array}$ & 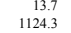 & $\begin{array}{r}13.1 \\
1252.2\end{array}$ & $\begin{array}{r}12.4 \\
1390.6\end{array}$ & $\begin{array}{r}11.7 \\
1540.1\end{array}$ & $\begin{array}{r}10.9 \\
1703.5\end{array}$ & $\begin{array}{r}10.2 \\
1890.4\end{array}$ & $\begin{array}{r}9.4 \\
2077.6\end{array}$ & $\begin{array}{r}8.6 \\
2268.6\end{array}$ & $\begin{array}{r}18.6 \\
365.0\end{array}$ & $\begin{aligned} 11.9 & \\
1.514 .4 & \end{aligned}$ \\
\hline \\
\hline debt & 174.5 & 153.6 & 147.8 & 87.9 & 90.0 & 90.9 & 90.1 & 87.1 & 86.5 & 87.6 & 88.1 & 88.5 & 88.9 & 89.4 & 89.9 & 90.5 & 91.3 & 92.1 & 93.4 & 94.1 & 94.4 & 107.7 & 91.3 \\
\hline & & & & & 90.0 & & & & & & 88.1 & 88.5 & 88.9 & 89.4 & 89.9 & 90.5 & 91.3 & 92.1 & 93.4 & 94.1 & & 101.9 & 91.3 \\
\hline Total debt & 243.8 & 210.9 & 188.8 & 109.3 & 108.3 & 105.6 & 100.7 & 96.6 & 94.4 & 93.8 & 92.7 & 91.4 & 90.2 & 89.2 & 88.3 & 87.6 & 87.1 & 86.7 & 86.8 & 86.4 & 85.6 & 131.3 & 87.9 \\
\hline Total debt, assuming fiul delivery & & & & & & & & & & & & & & & & & & & & & & & \\
\hline
\end{tabular}

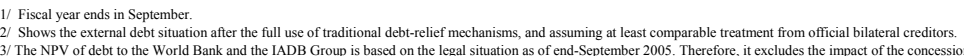

$3 /$ The NPV of debt to the World Bank and the IADB Group is based on the legal situation as of end-September.

5 Assumes interim relief under the enhanced lnititaitic from Novermber 2006 to September 2008 and full delivery of assistance in September 2008.

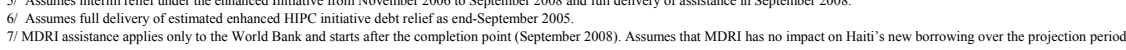


Table A6. Republic of Haiti: External Debt Indicators, 2005-25 1/

Averages

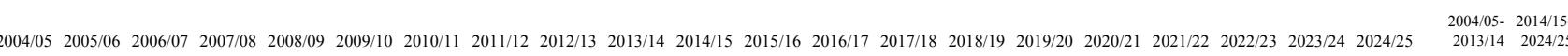

Before traditional debt relief

NPV of debt-to-GDP ratio

NPV of debt-to-revenue ratio $4 /$

Debt service ratio

Debt service-to-revenue ratio 4

After traditional debt relief

NPV of debt-to-GDP ratio

NPV of debt-to-revenue ratio $4 /$

Debt service ratio

Debt service-to-revenue ratio 4 /

After conditional delivery of enhanced HIPC assistance

NPV of debt-to-GDP ratio

NPV of debt-to-exports ratio $2 / 3 /$

of debt-to-revenue ratio

Debt service-to-exports ratio
Debt service-to-revenue ratio

After unconditional delivery of enhanced HIPC assistance

NPV of debt-to-GDP ratio

t-to-exports ratio $2 / 3 /$

$3 /$

ratio (existing debt only)

of debt-to-revenue ratio 4

Debt service-to-revenue ratio

After conditional delivery of

NPV of deb-to-GDP ratio

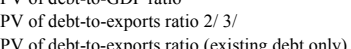

NPV of debt-to-revenue ratio

Debt service-to-exports ratio

Sources: Haitian authorities and staff estimates and projections

2/Exports are defined as in IMF, Balance of Payments Manual, 5th edition, 1993

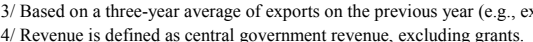

4/ Revenue is defined as central government revenue, excluding grants.

5/MDRI assistance applies only to the World Bank and starts after the completion point (September 2008). Assumes that MDRI has no impact on Haiti's new borrowing over the projection period.

\section{(In percent, unless otherwise indicated)}

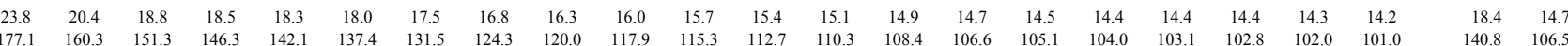

$\begin{array}{llllllllllllllllllllll}2202 & 193.3 & 181.7 & 171.1 & 159.7 & 146.9 & 137.7 & 131.0 & 126.2 & 121.2 & 116.4 & 112.0 & 108.1 & 104.7 & 101.8 & 99.2 & 97.0 & 95.5 & 93.6 & 91.5 & 171.5 & 103.7\end{array}$

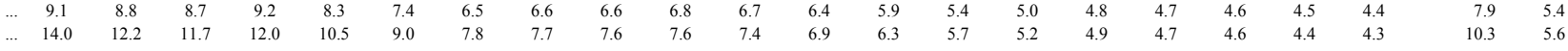

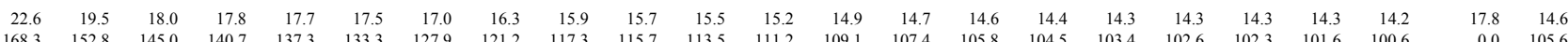

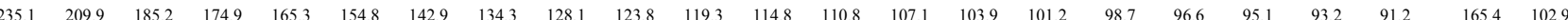

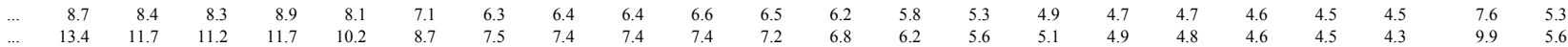

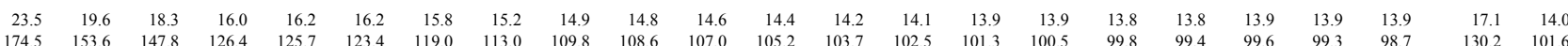

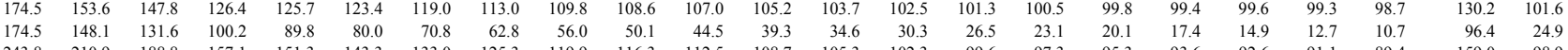

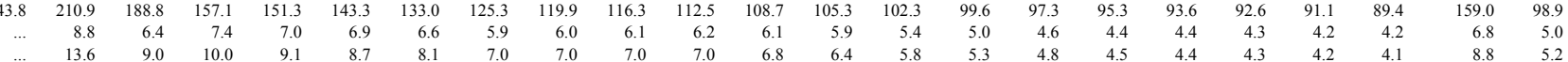

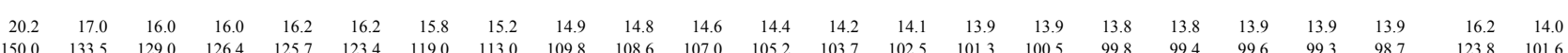

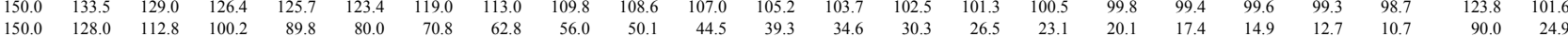

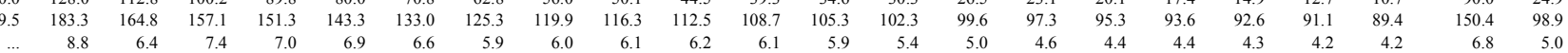
(13.

$\begin{array}{lllllllllllllllllllllll}23.5 & 19.6 & 18.3 & 11.1 & 11.6 & 11.9 & 12.0 & 11.8 & 11.7 & 11.9 & 12.0 & 12.1 & 12.2 & 12.3 & 12.4 & 12.5 & 12.7 & 12.8 & 13.1 & 13.2 & 13.3 & 14.3 & 12.6 \\ 174.5 & 153.6 & 147.6 & 61.7 & 54.1 & 47.5 & 41.9 & 36.9 & 32.7 & 29.0 & 25.6 & 22.5 & 19.7 & 17.2 & 15.1 & 13.2 & 11.5 & 10.1 & 8.7 & 7.5 & 6.5 & 15.8 & 14.3\end{array}$

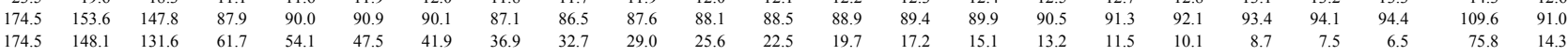

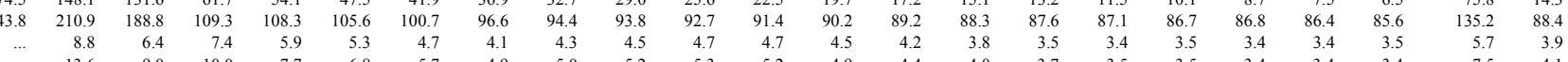

\begin{tabular}{ll}
7.5 & 4.1 \\
\hline
\end{tabular} 
Table A7. Republic of Haiti: External Debt Indicators and Sensitivity Analysis, 2005-25 1/

Averages

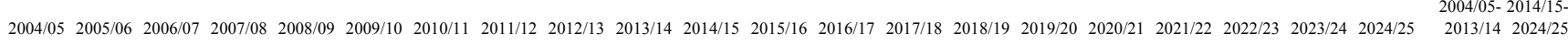

Baseline scenario

NPV of debt-to-GDP ratio

NPV of debt-to-exports ratio $2 / 3 /$

Debt serviceto exports ratio

Debt service-to-revenue ratio

(n percent, unless otherwise indicated)

Sensitivity analysis

$\mathrm{NPV}$ of debt-to-exports ratio $2 / 3 /$

$\mathrm{NPV}$ of debt-to-revenue ratio 4

Debt service-to-exports ratio
Debt service-to-revenue ratio 4

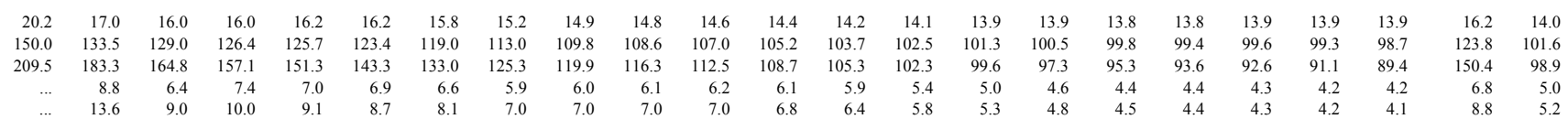

Lower export growth 6

NPV of debt-to-exports ratio $2 / 3 /$

NPV of debt-to-revenue ratio 4

Debt service-to-exports ratio

Debt service-to-revenue ratio $4 /$

Lower GDP growth $7 /$

$\checkmark$ of debt-to-exports ratio $2 / 3 /$

Debt service-tevenue ratio $4 / 2$

Debt service-to-revenue ratio 4

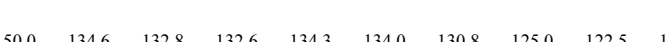

$7.0 \quad 6.8$

$\begin{array}{llllllllllllll}122.5 & 121.9 & 120.9 & 120.1 & 119.4 & 118.6 & 118.0 & 117.6 & 117.5 & 118.1 & 117.9 & 117.3 & 131.9 & 118.8 \\ 131.1 & 12.1 & 12.9 & 121.9 & 119.1 & 1165 & 6.0 & 5.8 & 5.8 & 5.7 & 5.7 & 5.6 & 159.6 & 1156\end{array}$

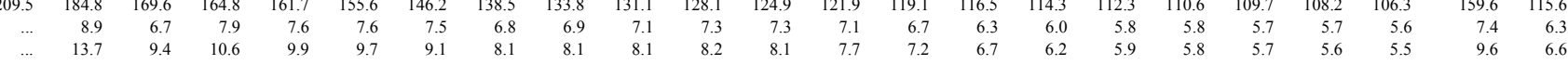

\begin{tabular}{lllllllllllllllllllllll}
150.0 & 136.1 & 135.9 & 139.1 & 144.1 & 147.6 & 149.1 & 147.4 & 148.0 & 150.6 & 152.8 & 154.9 & 157.5 & 160.5 & 164.0 & 168.1 & 172.7 & 178.0 & 184.4 & 190.3 & 195.9 & 144.8 & 170.8 \\
\hline
\end{tabular}

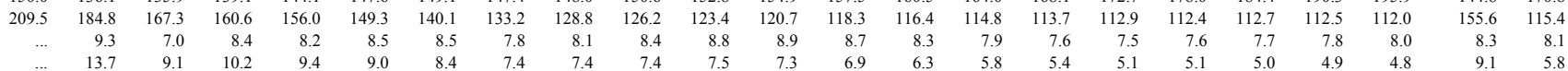

\begin{tabular}{lllllllllllllllllllllll}
150.0 & 133.8 & 130.0 & 128.3 & 128.9 & 128.2 & 125.8 & 122.1 & 121.4 & 123.2 & 124.8 & 126.5 & 128.8 & 131.6 & 134.7 & 138.3 & 142.3 & 146.8 & 152.0 & 156.8 & 161.6 & 129.2 & 140.4 \\
\hline
\end{tabular}

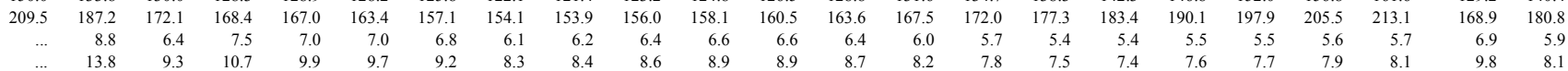

Sources: Haitian authorities and staff estimates and projections.

1/ All debt indicators refer to public and publicly guaranteed (PPG) debt and are defined after HIPC assistance assumed delivered unconditionally at end-September 2005. Fiscal year ends in September.

2/ As defined in IMF, Balance of Payments Manual, 5th edition, 1993

3/ Based on a three-year average of exports on the previous year (e.g., export average over 1999-2001 for NPV of debt-to-exports ratio in 2001).

$5 /$ Assumes that the interest rate on all debt is 1 percentage point higher the

6/ Assumes on average 3 perceense

7/ Assumes 2 percentage points lower GDP growth 2006-26. 
Table A8. HIPC Initiative: Status of Country Cases Considered Under the Initiative, May 3, 2006

\begin{tabular}{|c|c|c|c|c|c|c|c|c|c|c|c|}
\hline \multirow[b]{3}{*}{ Country } & \multirow{3}{*}{$\begin{array}{r}\text { Decision } \\
\text { Point }\end{array}$} & \multicolumn{3}{|c|}{$\begin{array}{c}\text { Target } \\
\text { NPV of Debt-to- }\end{array}$} & \multirow{2}{*}{\multicolumn{5}{|c|}{$\begin{array}{c}\text { Assistance Levels 1/ } \\
\text { (In millions of U.S. dollars, present value) }\end{array}$}} & \multirow{3}{*}{$\begin{array}{c}\text { Percentage } \\
\text { Reduction } \\
\text { in NPV of } \\
\text { Debt } 2 / \\
\end{array}$} & \multirow{3}{*}{$\begin{array}{c}\text { Estimated Total } \\
\text { Nominal Deb } \\
\text { Service Relief } \\
\text { (In millions of } \\
\text { U.S. dollars) }\end{array}$} \\
\hline & & \multirow{2}{*}{$\begin{array}{r}\text { Completion } \\
\text { Point }\end{array}$} & \multicolumn{2}{|c|}{$\frac{\text { NPV of Debt-to- }}{\text { Gov. }}$} & & & & & & & \\
\hline & & & $\frac{\text { Exports }}{\text { (in pe }}$ & $\frac{\text { revenue }}{\text { rent) }}$ & Total & $\begin{array}{l}\text { Bilateral and } \\
\text { commercial }\end{array}$ & $\begin{array}{l}\text { Multi- } \\
\text { lateral }\end{array}$ & IMF & $\begin{array}{r}\text { World } \\
\text { Bank } \\
\end{array}$ & & \\
\hline \multicolumn{12}{|c|}{ Completion point reached under enhanced framework } \\
\hline Benin & Jul. 00 & Mar. 03 & 150 & & 265 & 77 & 189 & 24 & 84 & 31 & 460 \\
\hline Bolivia & & & & & 1,302 & 425 & 876 & 84 & 194 & & 2,060 \\
\hline original framework & Sep. 97 & Sep. 98 & 225 & & 448 & 157 & 291 & 29 & 54 & 14 & 760 \\
\hline enhanced framework & Feb.00 & Jun. 01 & 150 & & 854 & 268 & 585 & 55 & 140 & 30 & 1,300 \\
\hline Burkina Faso & & & & & 553 & 83 & 469 & 57 & 231 & & 930 \\
\hline original framework & Sep. 97 & Jul. 00 & 205 & & 229 & 32 & 196 & 22 & 91 & 27 & 400 \\
\hline enhanced framework & Jul. 00 & Apr. 02 & 150 & & 195 & 35 & 161 & 22 & 79 & 30 & 300 \\
\hline topping-up & $\ldots$ & Apr. 02 & 150 & & 129 & 16 & 112 & 14 & 61 & 24 & 230 \\
\hline Cameroon & Oct. 00 & Apr. 06 & 150 & & 1,267 & 879 & 322 & 37 & 176 & 27 & 4,917 \\
\hline Ethiopia & & & & & 1,982 & 637 & 1,315 & 60 & 832 & & 3,275 \\
\hline enhanced framework & Nov. 01 & Apr. 04 & 150 & & 1,275 & 482 & 763 & 34 & 463 & 47 & 1,941 \\
\hline topping-up & & Apr. 04 & 150 & & 707 & 155 & 552 & 26 & 369 & 31 & 1,334 \\
\hline Ghana & Feb. 02 & Jul. 04 & 144 & 250 & 2,186 & 1,084 & 1,102 & 112 & 781 & 56 & 3,500 \\
\hline Guyana & & & & & 591 & 223 & 367 & 75 & 68 & & 1,354 \\
\hline original framework & Dec. 97 & May 99 & 107 & 280 & 256 & 91 & 165 & 35 & 27 & 24 & 634 \\
\hline enhanced framework & Nov. 00 & Dec-03 & 150 & 250 & 335 & 132 & 202 & 40 & 41 & 40 & 719 \\
\hline Honduras & Jul. 00 & Mar- 05 & 110 & 250 & 556 & 215 & 340 & 30 & 98 & 18 & 1,000 \\
\hline Madagascar & Dec. 00 & Oct-04 & 150 & & 836 & 474 & 362 & 19 & 252 & 40 & 1,900 \\
\hline Mali & & & & & 539 & 169 & 370 & 59 & 185 & & 895 \\
\hline original framework & Sep. 98 & Sep. 00 & 200 & & 121 & 37 & 84 & 14 & 43 & 9 & 220 \\
\hline enhanced framework & Sep. 00 & Mar. 03 & 150 & & 417 & 132 & 285 & 45 & 143 & 29 & 675 \\
\hline Mauritania & Feb. 00 & Jun. 02 & 137 & 250 & 622 & 261 & 361 & 47 & 100 & 50 & 1,100 \\
\hline Mozambique & & & & & 2,023 & 1,270 & 753 & 143 & 443 & & 4,300 \\
\hline original framework & Apr. 98 & Jun. 99 & 200 & & 1,717 & 1,076 & 641 & 125 & 381 & 63 & 3,700 \\
\hline enhanced framework & Apr. 00 & Sep. 01 & 150 & & 306 & 194 & 112 & 18 & 62 & 27 & 600 \\
\hline Nicaragua & Dec. 00 & Jan. 04 & 150 & & 3,308 & 2,175 & 1,134 & 82 & 191 & 73 & 4,500 \\
\hline Niger & & & & & 663 & 235 & 428 & 42 & 240 & & 1,190 \\
\hline enhanced framework & Dec. 00 & Apr. 04 & 150 & & 521 & 211 & 309 & 28 & 170 & 53 & 944 \\
\hline topping-up & $\ldots$ & Apr. 04 & 150 & & 143 & 23 & 119 & 14 & 70 & 25 & 246 \\
\hline Rwanda & & & & & 696 & 65 & 631 & 63 & 383 & & 1,316 \\
\hline enhanced framework & Dec. 00 & Apr-05 & 150 & & 452 & 56 & 397 & 44 & 228 & 71 & 839 \\
\hline topping-up & $\ldots$ & Apr-05 & 150 & & 243 & 9 & 235 & 20 & 154 & 53 & 477 \\
\hline Senegal & Jun. 00 & Apr. 04 & 133 & 250 & 488 & 212 & 276 & 45 & 124 & 19 & 850 \\
\hline Tanzania & Apr. 00 & Nov. 01 & 150 & & 2,026 & 1,006 & 1,020 & 120 & 695 & 54 & 3,000 \\
\hline Uganda & & & & & 1,003 & 183 & 820 & 160 & 517 & & 1,950 \\
\hline original framework & Apr. 97 & Apr. 98 & 202 & & 347 & 73 & 274 & 69 & 160 & 20 & 650 \\
\hline enhanced framework & Feb.00 & May 00 & 150 & & 656 & 110 & 546 & 91 & 357 & 37 & 1,300 \\
\hline Zambia & Dec. 00 & Apr-05 & 150 & & 2,499 & 1,168 & 1,331 & 602 & 493 & 63 & 3,900 \\
\hline Decision point reached under & inced framew & & & & & & & & & & \\
\hline Burundi & Aug. 05 & Floating & 150 & & 826 & 124 & 701 & 28 & 425 & 92 & 1,465 \\
\hline Chad & May. 01 & Floating & 150 & & 170 & 35 & 134 & 18 & 68 & 30 & 260 \\
\hline Congo, Democratic Rep. of & Jul. 03 & Floating & 150 & & 6,311 & 3,837 & 2,474 & 472 & 831 & 80 & 10,389 \\
\hline Congo Rep. of & Mar. 06 & Floating & & 250 & 1,679 & 1,561 & 118 & 8 & 49 & 32 & 2,881 \\
\hline Gambia, The & Dec. 00 & Floating & 150 & & 67 & 17 & 49 & 2 & 22 & 27 & 90 \\
\hline Guinea & Dec. 00 & Floating & 150 & & 545 & 215 & 328 & 31 & 152 & 32 & 800 \\
\hline Guinea-Bissau & Dec. 00 & Floating & 150 & & 416 & 212 & 204 & 12 & 93 & 85 & 790 \\
\hline Malawi & Dec. 00 & Floating & 150 & & 643 & 163 & 480 & 30 & 331 & 44 & 1,000 \\
\hline São Tomé and Príncipe & Dec. 00 & Floating & 150 & & 97 & 29 & 68 & - & 24 & 83 & 200 \\
\hline Sierra Leone & Mar. 02 & Floating & 150 & & 600 & 205 & 354 & 123 & 122 & 80 & 950 \\
\hline Decision point reached under ori & 1 framework & & & & & & & & & & \\
\hline Côte d'Ivoire & Mar. 98 3/ & $\ldots$ & 141 & 280 & 345 & 163 & 182 & 23 & 91 & 64 & 800 \\
\hline Total assistance provided/com & & & & & 34,756 & 17,239 & 17,377 & $\mathbf{2 , 5 8 8} 5 /$ & 8,203 & & 61,221 \\
\hline Preliminary HIPC document issu & & & & & & & & & & & \\
\hline Côte d'Ivoire 6/ & $\ldots$ & $\ldots$ & 91 & 250 & 2,569 & 1,027 & 918 & 166 & 438 & 37 & 3,900 \\
\hline
\end{tabular}

Sources: IMF and World Bank Board decisions, completion point documents, decision point documents, preliminary HIPC documents, and staff calculations.

1/ Assistance levels are at countries' respective decision or completion points, as applicable.

2/ In percent of the net present value of debt at the decision or completion point (as applicable), after the full use of traditional debt-relief mechanisms.

/ Côte d'Ivoire reached its decision point under the original framework in March 1998. The total amount of assistance committed thereunder was US\$345 million in NPV terms.

4/ Nonreschedulable debt to non-Paris Club official bilateral creditors and the London Club, which was already subject to a highly concessional restructuring, is

excluded from the NPVof debt at the completion point in the calculation of this ratio.

5/ Equivalent to SDR 1,804 million at an SDR/USD exchange rate of 0.6765 , as of May $3,2006$.
6/ It is suggested that enhanced HIPC relief for Côte d'Ivoire overtake the commitments made under the original HIPC framework. 
Table A9. Republic of Haiti: Possible Delivery of IMF Assistance under the Enhanced HIPC Initiative, FY2007-2016 1/

(In millions of U.S. dollars, unless otherwise indicated)

\begin{tabular}{|c|c|c|c|c|c|c|c|c|c|c|}
\hline & FY2007 & FY2008 & FY2009 & FY2010 & FY2011 & FY2012 & FY2013 & FY2014 & FY2015 & FY2016 \\
\hline \multicolumn{11}{|l|}{ (Based on the US\$/SDR exchange rate as of June 15, 2006) } \\
\hline Delivery schedule of IMF assistance (in percent of the total assistance) & 20.0 & 20.0 & 55.0 & 5.0 & - & - & - & - & - & - \\
\hline Debt Service due on IMF obligations 2/3/ & 4.0 & 5.5 & 14.6 & 12.0 & 2.2 & 0.3 & 0.3 & 0.3 & 0.3 & 0.3 \\
\hline Principal & 2.3 & 3.8 & 13.3 & 11.4 & 1.9 & - & - & - & - & - \\
\hline Interest and charges & 1.8 & 1.7 & 1.3 & 0.6 & 0.3 & 0.3 & 0.3 & 0.3 & 0.3 & 0.3 \\
\hline \multicolumn{11}{|l|}{ IMF assistance--deposits into Haiti's Umbrella Account } \\
\hline Interim assistance $4 /$ & 0.6 & 0.6 & & & & & & & & \\
\hline Completion point assistance 5/ & & 1.9 & & & & & & & & \\
\hline IMF assistance--drawdown schedule from Haiti's Umbrella Account & 0.6 & 0.6 & 1.8 & 0.2 & -- & -- & -- & -- & -- & -- \\
\hline IMF assistance without interest & 0.6 & 0.6 & 1.7 & 0.2 & -- & & - & - & - & - \\
\hline Estimated interest earnings 6/ & 0.0 & 0.0 & 0.1 & 0.1 & -- & -- & -- & -- & -- & -- \\
\hline Debt service due on current IMF obligations after IMF assistance & 3.4 & 4.9 & 12.8 & 11.8 & 2.2 & 0.3 & 0.3 & 0.3 & 0.3 & 0.3 \\
\hline \multicolumn{11}{|l|}{ Share of debt service due on IMF obligations covered by } \\
\hline IMF assistance (in percent) & 15.4 & 11.3 & 12.5 & 2.0 & -- & -- & -- & -- & -- & -- \\
\hline \multicolumn{11}{|l|}{$\begin{array}{l}\text { Proportion (in percent) of each repayment falling due } \\
\text { during the period to be paid by IMF Initiative assistance from the } \\
\text { principal deposited in Umbrella Account }\end{array}$} \\
\hline \multicolumn{11}{|l|}{$\begin{array}{l}\text { Memorandum items: } \\
\text { (Based on debt service data and exchange rates as of end-September 2005) }\end{array}$} \\
\hline Total debt service due (in millions of U.S. dollars) & -- & -- & -- & -- & -- & -- & -- & -- & -- & -- \\
\hline Debt service due on IMF obligations (in millions of U.S. dollars) & 2.8 & 4.3 & 7.7 & 3.8 & -- & -- & -- & -- & -- & -- \\
\hline Debt service due on current IMF obligations after IMF assistance & 2.2 & 3.6 & 5.9 & 3.5 & -- & -- & -- & -- & -- & -- \\
\hline (in percent of current year exports of goods and nonfactor services) & 0.3 & 0.5 & 0.7 & 0.4 & -- & -- & -- & -- & -- & -- \\
\hline
\end{tabular}

Source: Fund staff estimates and projections.

1/ Total IMF assistance under the enhanced HIPC Initiative is US\$ 2.15 million in NPV terms calculated on the basis of data available at the decision point, excluding interest earned on Haiti's account and on committed but undisbursed amounts as described in footnotes 5 and 6 . Assistance assumed to be delivered in fiscal year (from October of previous calendar year to September of current calendar year.) 2/ Forthcoming obligations are as of end-April 2006. Interest obligations include net SDR charges and assessments.

3/ Debt service for FY2007 are obligations from October 2006 onwards.

4/ The first delivery of interim assistance will be deposited into Haiti's account at the expected decision point in October 2006 to cover principal obligations falling due to the Fund in November 2006. 5/ Most of the IMF's grant HIPC assistance assumed to be disbursed into Haiti's account at the completion point in September 2008, which is reflected in the calculation of interest.

6/ Includes estimated interest earnings on: (a) amounts held in Haiti's account; and (b) up to the completion point, amounts committed but not yet disbursed. It is assumed that these amounts earn a rate of return of

5.25 percent in U.S. dollar terms, but actual interest earnings may be higher or lower. Interest accrued during a calendar year will be used toward the first repayment obligation(s) falling due in the following

5.25 par in

obligations falling due during 2009-11. 
Table A10. Republic of Haiti: Possible Delivery of IDA Assistance under the Enhanced HIPC Initiative, FY2007-2016 1/ 2 /

(In millions of U.S. dollars, unless otherwise indicated)

$\begin{array}{llllllllll}\text { FY2007 } & \text { FY2008 } & \text { FY2009 } & \text { FY2010 } & \text { FY2011 } & \text { FY2012 } & \text { FY2013 } & \text { FY2014 } & \text { FY2015 } & \text { FY2016 }\end{array}$

I. Debt service to IDA before HIPC Initiative assistance 3/

Principa

\begin{tabular}{|c|c|c|c|c|c|c|c|c|c|}
\hline 14.6 & 14.9 & 15.4 & 16.3 & 16.7 & 16.9 & 16.8 & 16.8 & 18.2 & 19.6 \\
\hline 3.7 & 3.6 & 3.5 & 3.3 & 3.2 & 3.1 & 3.0 & 2.8 & 2.7 & 2.6 \\
\hline 9.3 & 14.9 & 7.7 & 12.0 & 16.7 & 16.9 & 16.8 & 16.8 & 18.2 & 19.6 \\
\hline 2.4 & 3.6 & 1.7 & 2.4 & 3.2 & 3.1 & 3.0 & 2.8 & 2.7 & 2.6 \\
\hline 6.6 & 0.0 & 9.4 & 5.2 & 0.0 & 0.0 & 0.0 & 0.0 & 0.0 & 0.0 \\
\hline 45.1 & ...... & 61.2 & 31.8 & $\ldots .$. & $\ldots \ldots$ & $\ldots \ldots$ & $\ldots \ldots$ & $\ldots \ldots$ & ( \\
\hline
\end{tabular}

IV. Percentage of debt service to IDA

covered by HIPC Initiative assistance

FY2008

FY2009

F 2010

FY2012

Y2013

II. Debt service to IDA after HIPC Initiative assistance

$$
\text { Principal }
$$

Interest

Memorandum Item:

Total nominal assistance

Source: World Bank staff estimates and projections.

1 / Fiscal year ends in September.

/ Does not include the direct impact of the concessional rescheduling of arrears in early 2005.

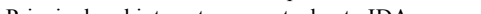

is to prorated projections based on the disbursed and outstanding debt as of end-September 2005, converted into U.S. dollars using the exchange rate as of endSeptember 2005. 
Table A11. Haiti: Long-Term Macroeconomic Assumptions, 2005-2.5 Fiscal Year Ending September 30

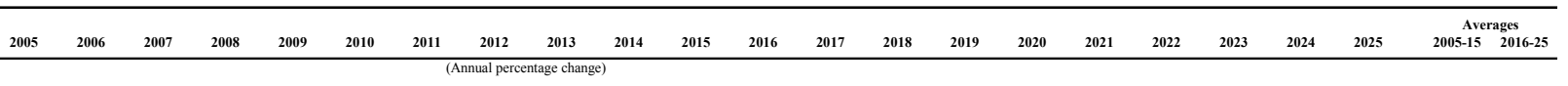

National income and price
GDP at constant prices

GDP at constant prices
GDP deflator

Real GDP per capita (percentage change, local currenes)

External sector
Exports of goods and non-factor service,

Central government

Central govermment revenue $1 / 1$
Central govermment expenditure

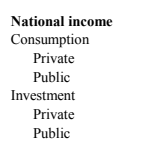

GDP per capit

External sector
Exports of goods and non-fictor services

External current tocount balne,e, betore HIPC debt relief

Liquid gross reserres (in months of imports of goods and services)

Central government
Central government overall balance $1 /$
Central government overall balance 2 .

Central government toveral balance 2
Total revenue and grants

Total revenute and grants
Centra goverment reverue $1 /$
Central government expenditure

1/Excluding gran
2/Including grant

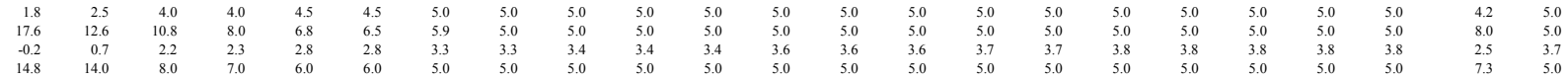

$\begin{array}{lllllllllllllllllllllll}17.1 & 10.4 & 9.5 & 8.5 & 9.2 & 9.5 & 9.4 & 7.0 & 7.1 & 7.3 & 7.5 & 7.1 & 7.3 & 7.4 & 7.5 & 7.4 & 7.5 & 7.6 & 7.4 & 7.5 & 7.6 & 9.3 & 7.4 \\ 13.7 & 14.3 & 9.2 & 6.3 & 6.3 & 6.2 & 5.9 & 5.4 & 7.5 & 7.5 & 7.2 & 7.2 & 7.3 & 7.3 & 7.3 & 7.4 & 7.4 & 7.5 & 7.6 & 6.9 & 7.0 & 8.1 & 7.3\end{array}$

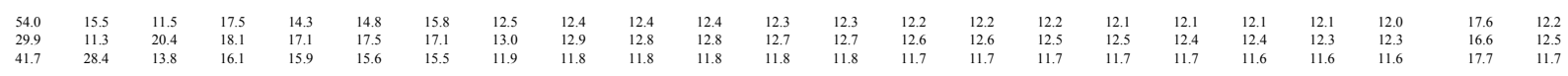

(In percent of GDP, unless otherwise indicated)

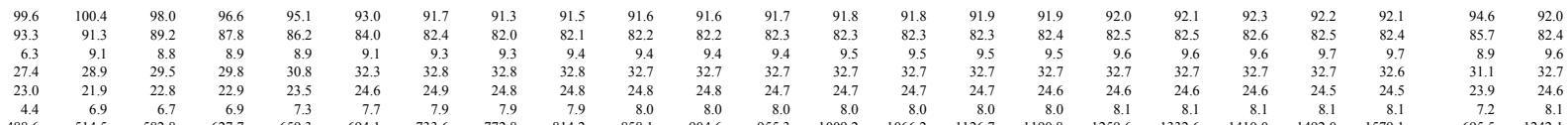

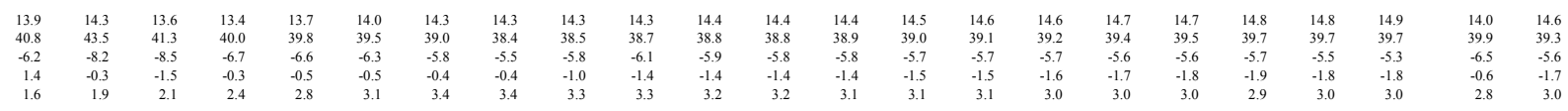

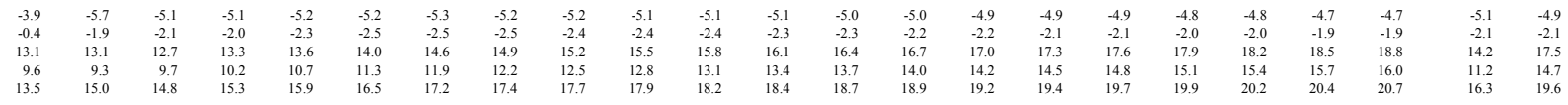




\section{Debt Management Capacity}

Currently, the Central Bank of the Republic of Haiti (Banque Centrale de la République d'Haït, BRH) and the Ministry of Economy and Finances (Ministère de l'Économie et des Finances, MEF) are jointly responsible for debt management in Haiti. While the BRH has a relatively complete debt database, the archives of the MEF were devastated by a fire in 2002. The MEF with support from the BRH is currently rebuilding its database. Overall, the coverage of public debt (external and domestic) is appropriate. The BRH updates its database at every payment cycle, ensuring that the authorities' database is broadly in line with the creditors.

A modern debt reporting system is installed at the $\mathrm{BRH}$, while the MEF is preparing to acquire such a system. Currently, the BRH uses an old version of UNCTAD's debt management system (DMFAS, version 5.2). Both the BRH and the MEF are considering acquiring an updated version of DMFAS. This would be contingent on the receipt of appropriate financing from donors and is also dependent on an assessment by a mission from UNCTAD. In addition to DMFAS, UNCTAD would also provide training to the staff of the BRH and the MEF. The use of an appropriate software and adequate training will be critical for improving debt management.

The following debt service procedures are typically followed. Every month, the BRH sends the MEF a statement of all debt service falling due in the following month. At the end of the months, the MEF issues a payment order for the full amount of debt service for the following month. The BRH debits the Treasury account to pay each creditor as debt service falls due. The BRH cannot legally pay a creditor without having information about the associated disbursement.

The BRH produces monthly, quarterly and annual reports which contain data on external debt. These reports cover the transactions (disbursements and payments) as well as the stock of debt and the accumulation of arrears. The reports are disseminated throughout the Central Bank and MEF. This allows the authorities to integrate the relevant information into the macroeconomic framework. The data are available to the public upon request within one month after the reference period, and are subsequently published with some additional delay.

Looking ahead, Haiti needs to further strengthen its debt management capacity by: (i) clarifying by law the debt management responsibility of the BRH and the MEF; (ii) improving information sharing, including frequent debt reconciliation exercises, between the BRH and the MEF; (iii) shortening the procedures for debt service payments; (iv) improving the tracking of disbursements; (v) acquiring a modern debt reporting system; (vi) training of staff; and (vii) improving the capacity to produce debt sustainability analyses. 